Saudi Journal of Humanities and Social Sciences

Abbreviated Key Title: Saudi J Humanities Soc Sci

ISSN 2415-6256 (Print) | ISSN 2415-6248 (Online)

Scholars Middle East Publishers, Dubai, United Arab Emirates

Journal homepage: https://saudijournals.com/sjhss

Review Article

\title{
Shaking a Spear at Ignorance: Shakespeare was the Tudor Princes Francis Bacon and Edward de Vere
}

Timothy Spearman

Toronto International College, 400-3550 Victoria Park Ave, North York ON M2H 2N5

DOI: 1 10.36348/sjhss.2020.v05i10.009 $\quad$ | Received: 24.09.2020 | Accepted: 08.10.2020 | Published: 16.10 .2020

*Corresponding author: Timothy Spearman

\section{Abstract}

This paper is the first to link both Tudor princes, changeling children and illegitimate sons of Queen Elizabeth I, Edward de Vere and Francis Bacon, to the Shakespeare plays. The author is also the first to discover a dramatic likeness in the countenance featured in the portraits of Edward de Vere and Shakespeare, which he shares in this paper. In addition, he found a dramatic likeness in the handwriting of four pages of original manuscript material from The Book of Thomas More and that of Francis Bacon, the editor and co-author of the Shakespeare works. In addition, this paper shares the discovery that there are four different spellings of the name William Shakespeare appearing on the title pages of the complete works, which suggests that there is a total of four different hands at work in the authoring of the plays. In addition, the 1623 Folio lists the authors name in all block capitals suggesting that the brand name is being used in the case of the collected works because a team is involved and not just a single author.

Keywords: Timothy Spearman is a former professor and presently a high school teacher at Toronto International School 400-3550 Victoria Park Ave., Toronto, Ontario, Canada.

Copyright () 2020 The Author(s): This is an open-access article distributed under the terms of the Creative Commons Attribution 4.0 International License (CC BY-NC 4.0) which permits unrestricted use, distribution, and reproduction in any medium for non-commercial use provided the original author and source are credited.

\section{INTRODUCTION}

This essay was originally inspired by a discovery the author made concerning a similarity in the likenesses of the subject featured in the portrait of William Shakespeare by John Taylor and that of Edward de Vere by the Dutch painter Marcus Gheeraerts the Younger. The conjecture is that the subject featured in the Taylor portrait of Shakespeare is the same man shown in the Gheeraerts portrait, only advanced in age by some 15 years and therefore with a receding hairline resulting from middle age. The hypothesis is that, having lost caste in the Elizabethan Court for acting in plays when it was expressly forbidden for aristocratic members of Court to do soin addition to causing other scandals, including having an affair with the Queen's handmaiden, Anne Vavasor-Edward de Vere, the 17th Earl of Oxford, the concealed Tudor prince and illegitimate son of Queen Elizabeth I, became increasingly defiant of the establishment, adopting a bohemian lifestyle and dress, growing what was left of his hair long, allowing his courtier goatee and mustache to grow into a full but scruffy beard, while sporting an earring and commoner's dress.
In addition, the essay connects Francis Bacon with the Shakespeare works through a comparison of the handwriting of four pages of original manuscript material from The Book of Thomas More and that of Francis Bacon. There is also evidence of Francis Bacon's role in the Shakespeare works provided in the form of embedded cipher messages found in plays and works written by or commissioned by Francis Bacon, which confirm that he played a crucial role in editing, and in some cases, writing some of the key passages in the works as evidenced by the doubling of the sizes of some of the Shakespeare plays, which occurred long after the death of Edward de Vere, implying that halfbrother Francis Bacon was in charge of editing the final versions of plays such as Hamlet.

The author known by the pen name William Shake-speare was actually a Freemason initiated into the higher degrees of Freemasonry and a British intelligence operative acting under the cover of a diplomat, who visited the courts of Europe on several occasions. The life of privilege led by the Tudor princes, and half-brothers, Edward de Vere and Sir Francis Bacon, so dwarfed the life of the mediocrity from Stratford-upon-Avon as to eliminate the latter altogether from the authorship candidacy. Why would 
the Stratford man so clearly support the ideology of caste and privilege, as evidenced by the early plays in particular, when such an ideology disqualified him from upward social mobility? In addition, it does not make any sense whatsoever that he would have such a breadth of knowledge gleaned from having participated in aristocratic sports, while studying jurisprudence, medicine, and several languages, in addition to traveling widely, when none of these privileges would have been open to the commoner from Stratford. It seems necessary to shake the spear of Athena at the ignorance of a naive world blinded by 400 years of incalculable oversight. The author hopes the findings here presented will sufficiently shake a spear at the serpent of ignorance that it might return to the hole it crawled out of. It is also hoped that the academic world, which has been so spitefully unkind to our person, will offer a warmer reception to this, our "spear-shaking."

What's in a name? In the name "William Shakespeare" there is a great deal. One would assume then that, as a name of great import, the author would at least endeavor to adopt a uniform spelling of his name and a uniform signature to go with it. Yet, of the six signatures found attached to documents ascribed to the man from Stratford, each displays a different spelling and style of handwriting. Why would this be when literate men of the 16th and 17th centuries developed personalized signatures just as people do today? As evidenced by the signatures extant, the man from Stratford, whose name was most commonly spelled 'Shakspere' but pronounced Shaxspur, seems not to have developed a consistent signature. Baptized Gulielmus Shakespere, he would go on to be known in other documents by William Shaxpere, William Shackespere, Willelmus Shackspere, William Shackspere, William Shakespeare of orthodox spelling, William Shackspeare, Willelmus Shakespeare, Willelmum Shakespeare, Willielmi Shakespeare, Willelmus Shackspere, Willelmus Shakspeare, Wyllyam Shaxpere, Mr. Shakespere, etc. These names appear on records ascribed to the man known by the name most commonly rendered "Will Shakspere" from Stratford-upon-Avon. It makes no sense whatsoever that a man of such purported literary fame and importance would not endeavor to standardize the spelling of his name as well as his own signature for simple purposes of identification if nothing else. Indeed, the fact that there seems to have been no effort on the part of the Stratford man to do so is where a good part of the confusion rests and has contributed in no small degree to the authorship problem itself. Some of the scholars who examined these records initially decided that some of these documents belong in the biography of some other man of that name. Scholar Sydney Lee, for example, concluded Anne Whately became engaged to another of the numerous "Shakespeares" who then abounded in the diocese of Worcester.
Then, in two articles entitled "Other William Shakespeares," Charles William Wallace established that one of the documents pertaining to malt sales should be reassigned to a man other than the Stratford man. So, the already scant record on the Stratford man, a record showing no evidence of any literary life, may be reduced still further when we consider that many of the "Shakespeares" referred to under different spellings in diverse documents may in fact be different men. The question that immediately springs to mind is why is the record so blank on William Shakspere of Stratford? Why is there such abject poverty in terms of documentation, including written records, letters, manuscript materials, etc.? Bear in mind that the question is asked of the man deemed to be the greatest author of English letters. How can this be, when significantly more documentation has been found for contemporaries of lesser note such as Ben Jonson and Michael Drayton? Drayton, a much less revered contemporary and fellow poet from the same town, has exactly the kind of documentation associated with him one would expect to find in the great Bard's record, including letters, direct references to works, a brief description of his physical appearance, evidence of revision and polishing of his works, evidence of attending educational institutions, etc. Why the comparative destitution in the Stratford man's record? And why is there no surviving evidence that these two famous poets from the same town had known each other or even met? [1].

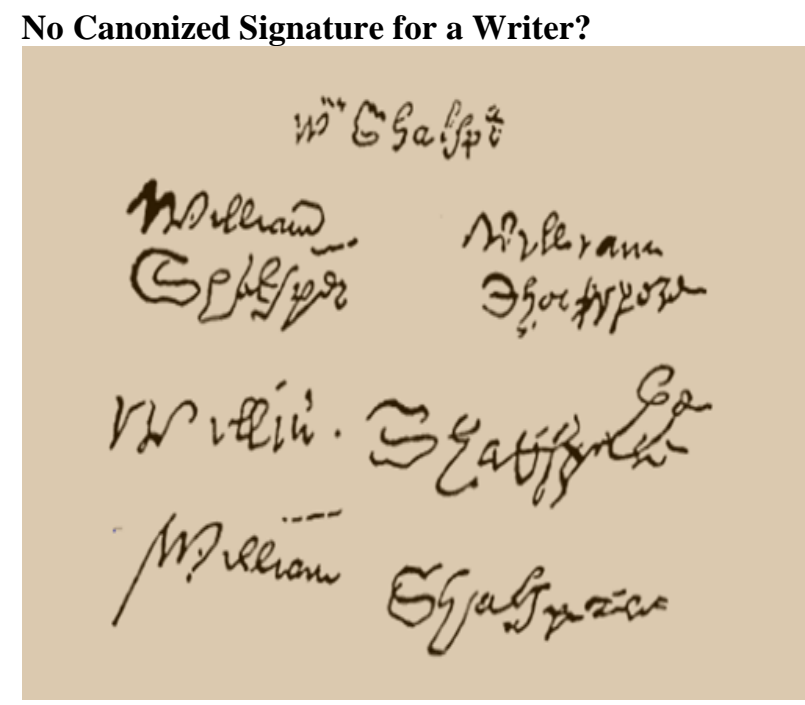

Shakespeare's signatures

There are no letters on record anywhere to any friends or relations to which William Shakespeare's signature is affixed. Nor are there any business partners to which his signature might appear in the course of correspondence. How could documentation of this kind related to one of history's most important men simply vanish from the historical record? We need to bear in mind that more essays and books are written about Shakespeare than any other historical personage. It just doesn't make sense that a figure so sought after should 
have so little to historically testify to his existence. How could the people of England have been so negligent about protecting their greatest cultural figure? Or is it rather the case that some kind of whitewash has been orchestrated to remove any vestige of evidence that might show the Stratford man to be a fraud with no connection whatsoever to the writing of these master works?

The signature on the Stratford man's last will and testament shows evidence of a man unfamiliar with a pen. The orthodox camp, the Stratfordians, argue that he was suffering from a terminal illness that had made his hand unsteady. But the claim of debilitating illness is contradicted by the avowal of the man himself in his last will and testament that he is of sound mind and body. There is also the fact that the testator of the will declares, "I have thereto put my Seal," with "Seal" crossed out and "hand" substituted. Are we to believe that the solicitor, being unaccustomed to having the Stratford man sign papers, prepares the will for his seal, then upon discovering him to be too ill to control his hand, has him sign three pages of the will anyway?

\section{What's in a Face?}

The Stratford bust of William Shakespeare features a square block topped by a jawless death's head and bearing Will Shakspere of Stratford's coat-ofarms on top of the memorial. The death's head is reminiscent of the one featured in the Freemason fraternity's skull and crossbones insignia represented in the Third Degree of Master Mason. The other odd feature is that the coat-of-arms is flanked by two Cupidlike figures, one bearing a spade and the other an hourglass. This is more code, not unlike the clues left on The Beatles' albums pointing to the replacement of deceased band member Paul McCartney. It seems to imply that the truth will be unearthed, uncovered or revealed in time. The most prominent feature is the bust itself, which appears wooden and lifeless. The first known depiction of the original monument is an engraving in Sir William Dugdale's Antiquities of Warwickshire, published in 1656. Depicting a sourlooking face with a drooping moustache, the subject clutches a sack, probably meant to be taken as a sack of grain. In the present bust, the Bard holds a pen in one hand and a sheet of paper under the other and both are resting on a cushion.
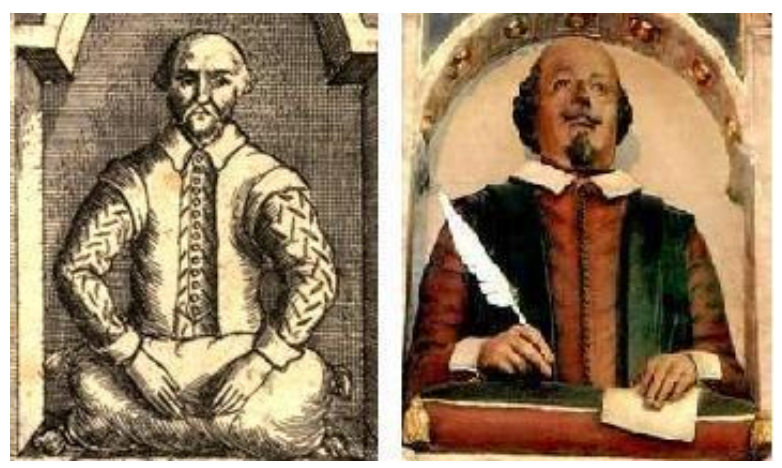

Nicholas Rowe, in his edition of Shakespeare's works in 1709, includes another engraving of the original Stratford monument much like the other, except that the subject's visage has been redrawn to render it less sour in appearance.

The epitaph inscription on the effigy of Shakespeare is shown below:

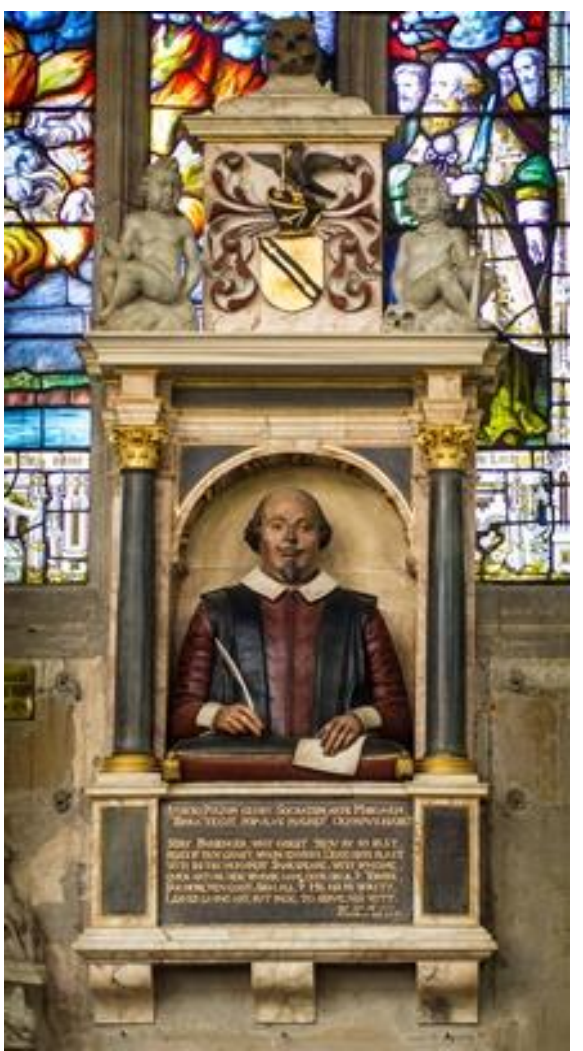

Shakespeare's funerary monument, Holy Trinity Church, Stratford

The Latin part of the inscription compares Shakespeare to Nestor, Socrates and Virgil, hardly an apt comparison for anyone familiar with these figures. People spoke of Shakespeare as being comparable to an English Ovid, not a Virgil. Another oddity is the fact that the inscription refers to the body being buried in the monument, when it is well-known that Shakspere, the Stratford man, was laid to rest under the floor beneath the stone bearing the well-known curse. The English inscription seems to be encouraging the viewer to entertain doubts: "Stay passenger, why goest thou by so fast?" Why should it be inferred that anyone should wish to pass by the bust of so great a figure unless the bust itself were unworthy of that figure? The inscription then asks the visitor to "Read if thou canst." Why would a visitor to the tomb of the immortal Bard be asked to read if he is able? Is it because he is thought to be too ignorant to understand that this cannot be a memorial bust to the true William Shakespeare? And why is the visitor told that envious death hath placed Shakespeare within this monument when it is obvious to anyone that the monument is too small to contain a 
body? Why especially when it would be known to many that the body of the Bard had been laid to rest under the floor beneath the stone bearing the famous curse?

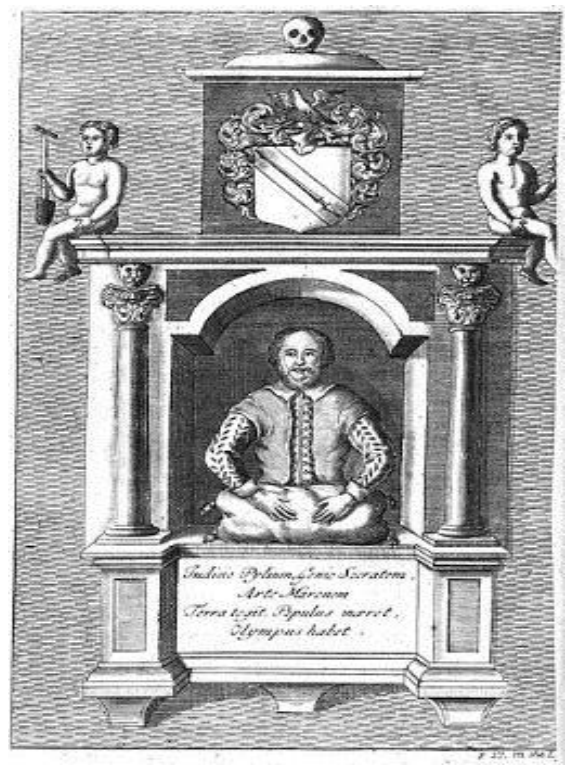

Sir Francis Bacon and company were Rosicrucians - his company being his writing guild or secret writing ministry, Fra Rosi Cross. The commemorative monument above, which stands in Stratford, is Rosicrucian through and through. Two famous pillars flank the bust, while above sit the two Cupids of Life and Death, well-known Rosicrucian emblems, representing the inverse factors of life and death. One Cupid holds an inverted torch, and with eyes closed, rests his hand on a skull. This represents Death, which quenches or puts out the flame of existence. But he is a Cupid nonetheless, a seducer, a lover that courts us till our hour of death, when he spirits us away. On the opposite side, is the Cupid of Life, with his back to the Cupid of Death. The Cupid of Life sits with eyes wide open, staring openly, with his right hand resting on a spade. The spade is a Rosicrucian symbol for the phallus, the instrument of sowing, planting the new seed in Mother Earth, in order to propagate new life and rebirth. The Cupid of Life is the seed-bearer, who causes new life to spring from Death. He reclaims Life from Death, grants immortality, the immortality of Nature and the soul [2].

In writing the dedication to the First Folio, Ben Jonson had written, "Thou art a monument without a tomb." He could hardly have had the Stratford man in mind when he wrote those words, since the Stratford man had already been buried by 1623 within a tomb. In the letter of dedication in the First Folio to the Earls of Pembroke and Montgomery, it is written: "We most humbly consecrate to your H.H. these remains of your servant Shakespeare." It is clear then that Shakespeare's works are the actual "remains" referred to. He was never buried since he was a monument without a tomb. A line from the inscription on the Stratford bust reads,
"WHOM ENVOIVS DEATH HATH PLAST WITH IN THIS MONUMENT SHAKSPEARE [3]."

When it is clear that the monument placed in the wall is too small to contain a body, it becomes apparent that it contains no body at all, or rather "nobody." The fact is that, if Shakespeare were not an interred corpse but a body of works, the interpretation of the inscription would change completely. In this case, the cryptic message becomes perfectly clear. The epitaphist, with good reason, entreats the reader not to hurry by without taking in what he is seeing. He urges the visitor to read, as in read carefully. The epitaphist seems to be suggesting to the visitor that he must surely know that Shakespeare's literal corpse cannot be contained within this monument, so he is asking in effect, "Where is it? Can you read? [4]" Then there is the poem by Leonard Digges in the introduction to the First Folio referring to a future, "when that stone is rent,/And Time dissolves the Stratford Monument . . . " Digges's then adds the comment, ". . . ev'ry line, each verse/here shall revive, redeeme thee from thy Hearse [5]." Then there is the monument referred to that holds the key to the riddle. First, there are the two Cupid-like children, one on either side. One child is holding a spade, and the other, an hourglass. The inference seems to be that when the time is right, the mystery will be revealed. The other noticeable feature is the jawless skull appearing at the top of the monument. Is it a reference to "envious death," which we are told placed Shakespeare in the monument? This recalls Ben Jonson's reference in the First Folio to the crafty malice that sought "to ruine" his beloved, the author. Could the internment of the manuscripts be considered the death imposed on that author, his silencing as depicted by the jawless skull, by that same malice? The suggestion has been made that the monument should be opened to see if it contains the written manuscripts, the body of work that would reveal the true author(s) of the Shakespeare works. It should show that the Tudor prince, Sir Francis Bacon, Viscount of St Albans, was the actual author of the plays, while the plots and writings of many of the plays seem to have been inspired by the colorful life of his older half-brother, Edward de Vere, the $17^{\text {th }}$ Earl of Oxford. The Shakespeare Birthplace Trust of Stratford has so far refused to consider the recommendation, but perhaps historians and archaeologists will win out in the end.

\section{Engravings that Embeds the Shakespeare Works upon the Mind}

The engraving below appears in a book attributed to Gustavus Selenus, an acquaintance of Lord Bacon, on the topic of cryptographic writing. The imprint at the end highlights a double ' $A$ ' ornament, representing Pallas Athena and Apollo, the twin spearshakers, who both brandished their spears at the twin serpents of ignorance and vice. As the goddess of the Greek theater, Pallas Athena enlightened the masses through the theater arts, driving off the twin serpents of 
ignorance and vice in the process. If one examines the engraved image below, one sees the true author handing his writing over to a Spearman dressed in actor's boots. This man is Shakspere of Stratford, as his face is a true likeness of the Stratford New House householder, Will Shakspere, which you will see if you compare this face with the Dugdale engraving on the previous page [6].

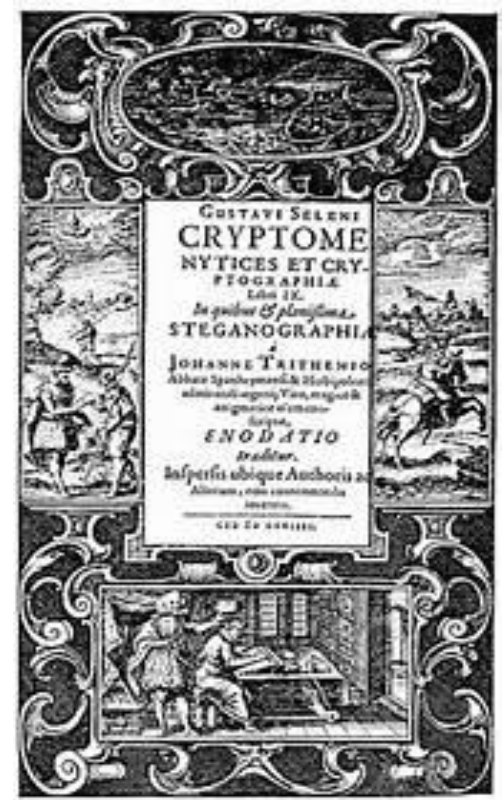

Title page of Cryptomenytices et Cryptographiae by Selenus

The above engraving appears to depict one of the illegitimate Tudor prince's writing the plays (bottom panel), and then passing them on to a middle man, who in turn passes them on to Will Shakspere (the man holding a spear in the middle-left panel). In the middle of the same panel, one can see a man still holding a spear. He is carrying books on his back, representing the Shakespeare plays. The mainstream view is that it depicts encoded military instructions being passed on to soldiers, but then this isn't entirely wrong since all the men involved in the Shakespeare authorship were members of Her Majesty's Secret Service and were members of the writing ministry Fra Rosi Cross aka The Honourable Order of the Knights of the Helmet, the secret writing ministry of Her Majesty's Secret Service (HMSS).

The engraving on the right side of the title page shows the same Spearman now riding a courser. He can be identified as the same man by the sprig of bay in his hat, but he is no longer a 'Shake-spear'; he is now a 'Shake-spur,' clearly identified by the carefully drawn and well rendered spur in his boot. The surname of Will Shakspere of Stratford was pronounced 'Shakspur [7].'

\section{Engravings on the Frontispiece of the First Folio \\ The portrait engraving of Shakespeare appearing on the cover of the First Folio was the work}

of Martin Droeshout, whose engraving is considered the standard portrait of Shakespeare, the one most frequently used to represent the Bard. Stratfordians attest to its authenticity, but Gainsborough, who was commissioned to paint a more promising representation of the Bard, made this surprising statement on the subject: "Damn the original portrait. I never saw a stupider face. It is impossible that such a mind and such a talent should shine with such a face and such a pair of eyes."

Lord Brain, Head of the Royal College of Physicians, commented in 1945 that the subject had been given two right eyes, since the outside corner of the eye on the right should manifestly be the inside corner. The fact that the subject has been given two right eyes is profoundly significant from an occult point of view. For anyone familiar with Freemasonry, it is the right eye of the Egyptian god Horus that is held to be sacred to the fraternity. According to Egyptian myth, after Osiris was slain in battle, his son Horus attempted to avenge his father's death by entering into a sword duel with the Egyptian god Set. In the ensuing sword battle, Horus lost an eye. Freemasonry is an expression of the All-Seeing Eye cult, which in occult terms represents the eye of Horus. To high initiates and perceptive researchers, the message in the eyes is clear: This is not the face of the true author, but that of the All-Seeing Eye who controls the dissemination of knowledge and information.

The journal Gentleman's Tailor noted in 1911 that the tunic is so strangely depicted that the right-hand side of the forepart is actually the left-hand side of the back part and gives a harlequin-like appearance to the figure, which is probably intentional. Then there is the line oft noted curving down from the distorted-looking ear to the chin, paralleling the line of the cheek. It corresponds to no line found on the human face, and would have been lost in shadow had it not been highlighted on either side. What is the line intended to represent? It has every appearance of being the edge of a mask, while the jab of the ear jutting out unnaturally to the side suggests that it is the aural appendage of a mask. Of the engraving itself, Ben Jonson refers to it in the dedication: "This figure, that thou here seest put,/ It was for gentle Shakespeare cut . . . [8]" Jonson's implication is that it is not an engraving of Shakespeare, but a figure that was cut for him. The word 'figure,' which is from the same root as 'feign,' implies that it is a false representation. Jonson adds, "Wherein the Graver has a strife with Nature to out-do the life . . [9]' The word 'Graver' is probably a pun on 'engraver' and 'gravedigger,' since the engraver has actually buried the true author behind a false façade. Ben Jonson's ironic dedication continues:

\section{BLOCK QUOTE BEGINS}

$\mathrm{O}$, could he but have drawn his wit

As well in brass, as he hath hit 
His face; the print would then surpass All, that was ever writ in brass. But, since he cannot, Reader, look Not on his picture, but his book [10].

\section{BLOCK QUOTE ENDS}

What Jonson seems to be entreating us to do is to not look at the picture to find the Bard but upon his works.

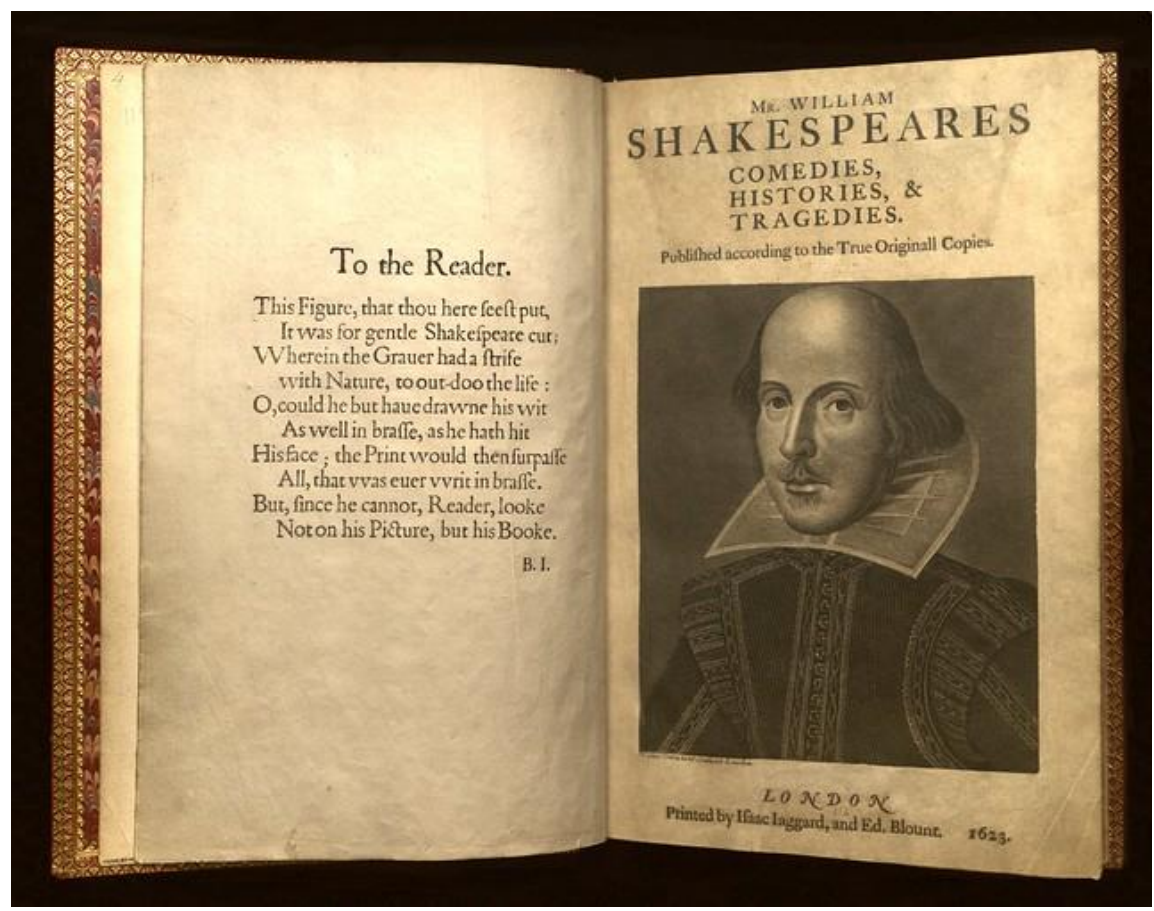

Engraving on Frontispiece 1640 Edition of Shakespeare's Poems

Poems Written By Wil. Shake-speare Gent, appeared in 1640. The engraving on the frontispiece is a reversal or mirror image of the face appearing on the frontispiece of the First Folio. The poetry anthology also contains a title-page indicating that copies of the publication are to be sold by John Benson. The fact that the name John Benson is an inversion of Ben Jonson matches the mirror-image inversion of the first Droeshout engraving that the second is intended to be. There is also the introduction to the poetry anthology signed I.B. just as Ben Jonson's introductory verse "To the Reader" in the First Folio was signed B.I. It is also noteworthy that a courtier's cape is draped over the subject's right shoulder [11]. The Bard is depicted holding an olive branch. The gift of an olive branch was presented as a gift by Pallas Athena, who caused it to spring from the barren rock of Attica, in gratitude to her champions. "And in thy hand the Spear of Pallas shake," we read in one of the poems included in the volume. The hyphenated surname "Shake-speare" is obviously a pen name, in which the author is naming himself after the patron goddess of drama. How can the reference to Pallas Athena, patron goddess of Athens and home of the Greek theater, escape the notice of any objective observer? Pallas Athena was nicknamed the Spear-shaker because of the fact that she awakened the minds and elevated the consciousness of her audience by inspiring the dramatic plays performed for their entertainment and edification. In short, she chased away the twin serpents of ignorance and vice by enlightening her public through theatrical spectacles. Pallas was called the Spear-shaker and so was the author, who was really the Tudor prince, Sir Francis Bacon. In the embedded cipher discovered by Elizabeth Gallup in The Bi-literal Cipher of Sir Francis Bacon, Bacon takes full credit for the Shakespeare plays. However, the title pages of the plays exhibit four different spellings of the Bard's name: William Shakespeare, William Shakespeare, William Shakespere, and W. SH. Then there is the title page for the 1623 Folio, which credits the authorship to WILLIAM SHAKESPEARE in all block capitals, suggesting a brand name, in which all contributing authors are credited. A close examination of the plays reveals that there is certainly more than one writing style and one author involved. Whether the Earl of Oxford, half-brother of Sir Francis Bacon, contributed to the Shakespeare canon is uncertain, since Francis mentions no such collaboration in any of his writings, nor does he include Oxford among the team members Bacon claims were in on the secret writing cipher messages discovered by Elizabeth Gallup. In the following secret writing passage, Bacon names the team members he claims were the only ones cognizant of the imbedded secret cipher coded messages.

\section{BLOCK QUOTE BEGINS}

Not along for pride in our choyse ' science for a field' of hard labour, but also that I might be at liberty to use these works as the exterior letter, hiding my secret writi'gs, as no other person is cogniza't of the work save my foster-brother Anthony, my owne brother Robert, Ben Jonson, my friend, adviser and assistant, 
and our private secretary, yet for the exterior part we emploie many amanuenses, for we can keep several employed when reading our plays for our finall review, or when assembling th' parts [12].

\section{BLOCK QUOTE ENDS}

Bacon has made it clear then that only four of his trusted inner circle are in on the imbedded cipher writings, but what he refers to as the 'exterior,' which is the overt plays and literary works rather than the covert writings, the team is considerably larger, which could leave room for Oxford and others to participate.

Most of the eight lines appearing in the verse beneath the portrait are taken from Ben Jonson's eulogy to Shakespeare. But the first two lines are transformed and given new meaning by the use of question marks. The meaning to be inferred from the question marks makes it obvious that the portrait is supposed to be questioned as a representation of Shakespeare: "This shadow is renowned Shakeseare's? Soul of th' age/The applause? Delight? The wonder of the stage [13].”

The writer is expressing considerable doubt that this 'shadow' actually represents the immortal Bard. The image characterized as a mere 'figure' in the First Folio is now at best a 'shadow.' The last two lines of verse carry the suspicion to another level: "For ever live thy fame, the world to tell,/Thy like, no age shall ever parallel [14]."

Having viewed the ironies contained in the engraving and those contained in the lines of verse appearing beneath the engraving, who could fail to see that there is a delightful game being played here and that efforts are being made to communicate something secret? To give the lines their true significance, reexamine them in light of the following:

\section{BLOCK QUOTE BEGINS}

For E. Ver live thy fame, the world to tell, Thy like, no age shall E. Ver parallel [15].

\section{BLOCK QUOTE ENDS}

What's in a face? The sheer abundance of disparate visages appearing in engravings and paintings of the Bard indicate that hardly anyone seems to have had a clear impression of what the man actually looked like. In the opinion of this writer, one of the only true likenesses of the author of the plays and sonnets, is the portrait of Shakespeare painted by John Taylor circa 1610. While Taylor's painting has been given the date 1610. While Oxford is generally believed to have died in 1604, he actually faked his death and was exiled to the penal island off the coast of Colchester, England, called Mersea Island. More astute researchers place the Earl of Oxford's death in 1609. The subject of the painting is indeed the man posterity knows as "William Shakespeare," but that man is not from Stratford-uponAvon, nor was his real name William Shakespeare. The portrait in fact bears a striking resemblance to Tudor prince, Edward de Vere. This begs the question of whether the Earl of Oxford, half-brother of fellow Tudor prince, Francis Bacon, contributed to the Shakespeare authorship. Unfortunately, there is nothing in Bacon's written testimony to attest to this.

Nevertheless, the man shown in Taylor's portrait bears a striking resemblance to a well-known portrait of de Vere painted by Marcus Gheeraerts. An approximate date for Gheeraerts's portrait is given as 1586. The marked difference that distinguishes this portrait from Gheeraerts's painting is the fact that the man appearing in the Taylor portrait is bald, while Gheeraerts's portrait features a man with a full head of hair. The reason for this is that the subject in Taylor's portrait is some 15 years older and has gone bald with advancing years, while the de Vere portrait depicts the same man in his prime and with a full head of hair. The subject featured in Taylor's portrait is most likely the same man featured in de Vere's portrait, only several years older. The de Vere portrait shows the same man at approximately 36 years of age, and the approximate date of 1586 given to the painting accords with this conjecture, since de Vere was born in 1550. Taylor's portrait therefore depicts de Vere at approximately 50 years of age, four years before his "official" death in 1604. The dating of the Taylor portrait would, therefore, have to be reassigned to circa 1600, 10 years earlier than that assigned by orthodoxy. Included in this chapter is a composite photo comparison of the subjects featured in the two paintings, where both the aging process and unkempt appearance is eliminated in the photoshopped painting of the Bard, restoring his full head of hair, while eliminating his earring and long hair in the process. Before and after photo analysis reveals that the middle-aged Bard bears a striking resemblance to Edward de Vere featured at the age of 36, suggesting that de Vere may hold some claim to the Shakespeare authorship.

When the essay "Shaking a Spear at Ignorance" was first submitted with the composite portrait painting analysis to the Shakespeare Quarterly, it was rejected. The Shakespeare Quarterly argued that, while the two men featured in the paintings bore no resemblance to one another whatsoever, the reviewers found the painting styles of Gheeraerts and Taylor strikingly similar. The author of this paper drew comfort from this admission as it proved that the reviewers apparently lacked both aesthetic judgment and visceral discernment, so it was no wonder they failed to detect a similarity in the likenesses of the two men, because the painting styles are decidedly different and bear no similarity to one another whatsoever. How, for instance, it could escape the review committee that the man featured in both portraits strikes the same pose and faces the portraitist at precisely the same angle in both portraits is another oversight on their parts. That they failed to note other similarities-like the courtier 
mustache and goatee, the distinctive pursed lips, and the same intelligent, slightly feminine eyes - shows even greater impoverishment of the senses. As for the differences in the portrait, it is perfectly logical that an intelligence agent of HMSS, while attempting to conceal his identity as the author, would pose for the portrait in the guise of the commoner he was purported to be as opposed to a nobleman. This was a fundamental part of the ruse. We therefore see a dramatic shift in dress to that of a person of the merchant class, the very class from which Shakespeare is supposed to have sprung. And since de Vere had lost caste in the Elizabethan Court for committing such sundry offenses - acting upon the stage, having an affair with the Queen's maid, etc.—donning the fashion of a commoner is a relatively easy transition for him to make late in life.
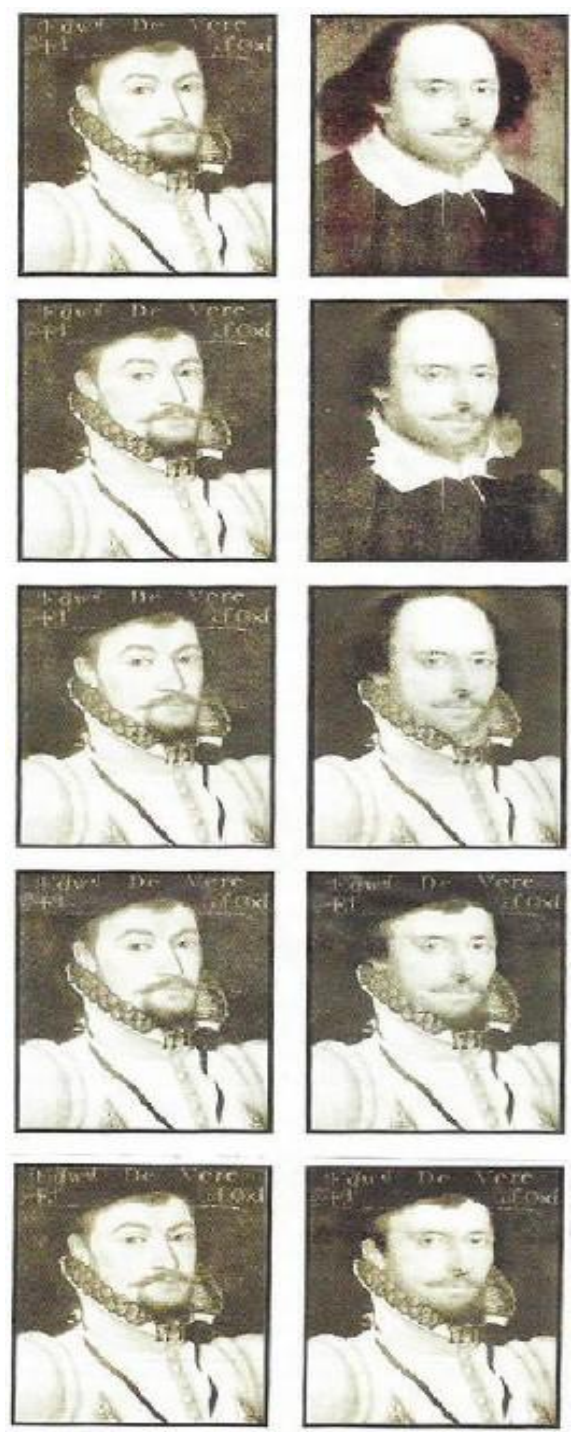

Featured at the top of the composite photo display, Oxford (left) age 36, and Oxford (right) as Shakespeare age 50

Is it mere oversight and a lack of discernment on the part of the Shakespeare Quarterly that has caused them to dismiss the merits of this discovery? This author thinks not. The academic community and the general public are apparently under the impression that all is aboveboard at the Shakespeare Quarterly. Are they aware of the scandal surrounding the Ashbourne Portrait of the Earl of Oxford that is also purported to be a portrait of William Shakespeare? Are they aware that this painting, which hangs in the Folger Shakespeare Library in Washington, D.C. was deliberately tampered with by its custodians? Would it be shocking to discover that the very museum gallery in charge of the running of the Shakespeare Quarterly actually painted over this portrait in order to disguise the evidence supporting the case for the Earl of Oxford being the Bard?

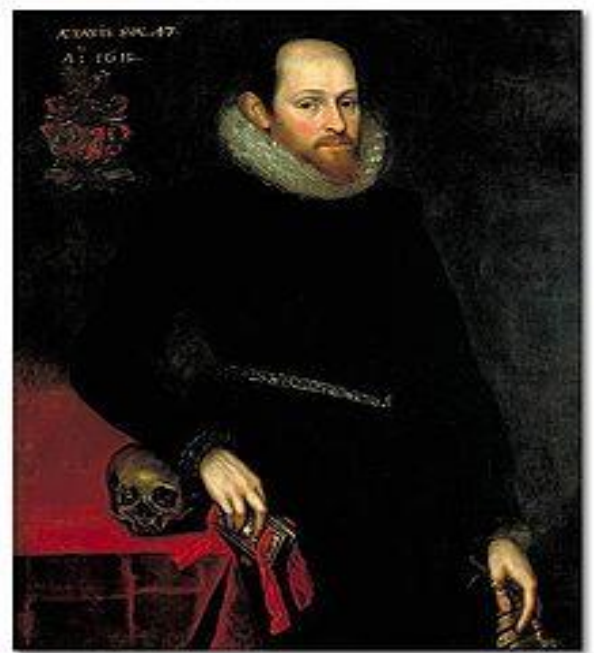

The Ashbourne Portrait by Marcus Gheeraerts

How can such obvious scholarly prejudice and suppression of evidence be possible by such a respectable publication? What if appearances were deceiving? What if the publication in question were not as respectable as it appeared to be on the surface? What if the Folger Shakespeare Library - the museum that runs the Shakespeare Quarterly - was implicated in a scandal involving historical fraud? The story commences with a man named Marion Harry Alexander Spielmann, whose careful analysis of the painting placed it in the Elizabethan Renaissance era. He reported his findings in Connoisseur Magazine in 1910, of which he was the editor. Spielmann identified a number of anomalies with the painting that were suggestive of tampering. The alterations to the painting appeared to have been made in order to have the sitter more closely resemble the common conception of what the Bard is thought to have looked like, based on the Droeshout engraving of the First Folio. Spielmann further noted that the hairline seemed to have been retouched, as had the rough around the throat. Later restorations by the Folger Shakespeare Library lowered the height of the skull, making the portrait conform with normal human proportions. A man named Charles Wisner Barrell published a Scientific American article in 1940 alleging, quite correctly, that the sitter of the Ashbourne Portrait was in fact de Vere. 
It happens that Barrell was in the PR division of Western Electric, in their Motion Picture Bureau. He had previously done a stint with the Rotograph Company, a subsidiary of Photographisce Gessellschaft of Berlin. Barrell was knowledgeable in photographic techniques and had expertise in the rotogravure process. In his Scientific American article, Barrell stated that an $\mathrm{X}$-ray analysis confirmed that alterations of the portrait had occurred, which conformed to those pointed out by Spielmann half a century before. The alterations made it patently obvious that attempts were made to make the portrait similar to the First Folio engraving and to change the date to 1611 to conform to the life timeline of the man from Stratford, who died in 1616. X-rays confirmed that the hairline had been deliberately receded to make the sitter appear balder and to enlarge the cranium unnaturally. Additional alterations were clearly meant to make the huge fluted ruffled collar more accommodating for a gentleman than a man of the Court. Barrell also pointed out that the date obscured the coat-of-arms in the upper left portion of the painting, which resembled the Trentham shield of his wife's family. In addition, he noticed how alterations to the sitter's thumb ring occulted the boar's head insignia that was Oxford's de Vere family symbol [16].

After the publication of the Scientific American article, the Folger Shakespeare Library did an about face on the issue. After maintaining for over a decade that the painting was actually that of the man from Stratford, it now declared the painting picta non grata. If that wasn't enough, the intellectual prostitutes working for this corrupt entity, then decided the sitter for the painting was Sir Hugh Hamersley, the mayor of London during the timeframe in question of the early 1600 s. The main reason for assigning the portrait to him seems to have been because he was born in 1565 , a year after the Stratford man, Will Shakspere. The Folger Shakespeare Library apparently needed to manufacture a sitter for the portrait that was anyone other than Oxford, since it wouldn't do to attribute the plays to anyone other than their assigned candidate, the Stratford man [17].

Apparently, this is because the truth truly will set us free, for when the ruse of the authorship is finally exposed, the public at large will recognize the tactics of the patsy frontman and see that it has been recycled for 400 years as the modus operandi of choice by the Anglo-American intelligence services. Maybe then they will see that Goldstein of Nineteen Eighty-Four is the prototype of the functional decoy the public is compelled to identify with, so that the covert operatives that orchestrate the crimes of the centuries get off scotfree. And maybe then, they will recognize Osama bin Laden as the CIA frontman agent he truly is, code named Tim Osmond. And maybe then, John Wilkes Booth, Lee Harvey Oswald, Manuel Noriega, Saddam Hussein, Timothy McVeigh, and assorted other patsy front men of history will be paraded in front of the documentary cameras to be exposed as the fronts they truly are.

Why is the Shakespeare Quarterly, attached to the Folger Shakespeare Library, based in Washington, D.C. in the first place? Is it so the hawks in Washington, D.C. can keep an eye on Shakespeare criticism so that, God forbid, the truth doesn't get out? It wouldn't do at all for the U.S. government's intelligence services to have their stratagem of the patsy front men exposed for public consumption, now would it? How then would they be able to dupe, hoodwink and deceive the world's citizens into chewing, swallowing and digesting their pack of lies? If a world-historical deception of this magnitude were to be exposed before a naïve world, there would be such hell to pay, it is doubtful there would be a Shakespeare Quarterly, let alone a museum gallery to house the historical treasures of a former empire.

Why are English literature departments at sundry universities around the world not up in arms about the Folger Shakespeare Library's fraudulent activities? Why is the most prestigious Shakespeare publication in the world still under the custodianship of a museum library that was found guilty of committing historical fraud and ordered by a U.S. court of law to restore the painting to its original integrity? These are provocative questions. The only reasonable answer is that university English literature departments either don't know, don't care or are deliberately suppressing the truth. Why? And how? Because the same secret societies that founded the Anglo-American intelligence services, most particularly Freemasonry and the Rosicrucian Society, are in control of our institutions of higher learning. The university degree system is based on the first three degrees of Freemasonry-Entered Apprentice, Fellow of the Craft, and Master Masonand they govern and control what gets taught and how it gets taught by implementing and running their own matriculation system.

So, when the student comes in at the bachelor's degree level, he is equivalent to the Freemason $1^{\circ}$ known as Entered Apprentice, and may read, write and think whatever he likes. The reason for this is that, the student who graduates with only this degree will never go on to occupy an influential position in society, and consequently their opinion matters not and is deemed to be of no significance whatsoever. However, if the student wishes to go on to the master's degree level to attain the equivalent standing of a $2^{\circ}$ Freemason-Fellow of the Craft-he will have to confine his area of research to the narrow parameters assigned to that academic degree. And if one intends to attain the coveted Ph.D. that will promote one to the highest echelons of society as the equivalent of a Master Mason, one will have to narrow one's area of research to the circumference of the head of a pin, in order to graduate as the narrow-minded 
'pinhead' the governing elite expects one to be. It's called "playing the game," and if one doesn't play it, one isn't allowed to play, because those are the rules. In order to maintain their coveted stranglehold on society, the same lies the professors learned during their apprenticeship have to be passed on to the new initiates if they wish to remain in the game. There has to be a reason the university degree system has been adopted around the world as the system of choice. It is a matter of degree, Mesdames et Messieurs, and it is a degree system based on the first three degrees of Freemasonry.

The Shakespeare authorship controversy is only one of the historical frauds perpetrated by a deeply corrupt academic world, but it is one of the most important because Shakespeare is the world's greatest icon. More articles and books are published each year about this man than any other figure in history. The authorship controversy is serious and deeply political and has been exacerbated by scholars making grossly erroneous claims and outright falsehoods. Perhaps the best example of this is Gareth and Barbara Lloyd Evans's grievously errant contention in their Companion to Shakespeare:

\section{BLOCK QUOTE BEGINS}

We know more about the life of Shakespeare, both in terms of facts and of rational conclusions that they suggest, than of any other Elizabethan dramatist . .

Documents relating to Shakespeare's activities, including letters to him and material relating to his family, are extant in quantity in the Shakespeare Centre records office at Stratford-upon-Avon [18].

\section{BLOCK QUOTE ENDS}

Note that the Evanses tell us that there are many "letters" extant to Shakespeare - that is "letters" in the plural-misleadingly implying that there are many such letters extant. The truth is, however, that there is only one letter on record addressed to William Shakspere, the man from Stratford, and it was never delivered [19]. How can so-called scholars mislead the public so irresponsibly? No wonder the authorship question has never been adequately resolved. With such gross distortions of the actual facts, many of the misinformed are discouraged from even embarking on the quest for the true author due to the erroneous weight of evidence tilting the balancing scales in favor of orthodoxy.

The surname "Shakespeare," it should be noted, appears as the hyphenated name, "Shakespeare," in the dedications to Venus and Adonis and Lucrece. Of the 30 editions of the Shakespeare plays published before the First Folio, in which authorial attribution was given, the name appeared hyphenated in 15 of these cases. This suggests that the name is a pseudonym. The only legitimate case for hyphenating an Anglo-Saxon name would be in the case of two noble families brought together through the bonds of marriage and who wish to retain their family peerage mutually by preserving both names in a hyphenated surname, but in such cases, the family name appearing after the hyphen would be capitalized. The "speare" in "Shake-speare" is most definitely not capitalized, leaving little doubt that the name itself is pseudonymous [20].

What's in a name? If a dramatist were to assign himself a pen name, would it not be apropos to take on a name that canonized him as a dramatist in some kind of homage to his art form? True, he would be under no obligation or compunction to do so; still, it would be most apropos. This being the case, it will come as no shock to learn that the name "Shake-speare" or "Shakespeare" is derived from Pallas Athena, patron goddess of the Greek theater in Athens, who was nicknamed Hasti-Vibrans in Latin, meaning the "Spearshaker." The reason assigned to the pen name for both the goddess and the Bard is that Pallas was known for shaking her spear at the twin serpents of ignorance and vice [21]. It should be noted that the theatrical arts were to ancient Athens and Elizabethan England what infotainment media is to modern audiences; it was the most efficient vehicle available for educating and enlightening the masses at the time. By inculcating new insights and awareness, it could ward off the serpent of ignorance. By ennobling and uplifting the masses through collective realization and enlightenment, it would drive off the serpent of vice through the inculcation of higher spiritual truths and values. In Greek mythology, Pallas Athena was the goddess of wisdom, philosophy, poetry, and the fine arts. Her original name was Pallas from palein, meaning 'shake.' Athens, the home of Greek drama, was under the guardianship of Pallas, the Spear-shaker. The phrase, "The spear of Pallas shake," can be read in a line of verse from a collection of Shakespeare's poems [22].

Pallas always shook her spear at ignorance, which is what the poet himself is doing, shaking his spear at the ignorant mass of humanity for believing the ridiculous ruse that an ignorant rustic from the country could be a claimant to the throne of the immortal Bard, as a mere stand-in, substitute, or understudy brought in to play the part so that the true author could remain behind the scenes, hidden from view. Pallas Athena also wore the "helmet of invisibility," which rendered her invisible each time she drew the visor down over her face. The Bard is, therefore, wearing Pallas's helmet of invisibility, as his true identity is concealed behind a mask or visor. Ben Jonson recognized the true significance of the pen name when he wrote of Shakespeare's "true-filled lines," that "In each of which, he seems to shake a lance,/As brandished in the eyes of ignorance [23]." How did Jonson know about the Pallas Athena connection unless he was in on the plot? Gabriel Harvey, a fellow at Trinity College, Cambridge, in an address to the Queen during one of her visits to the university in 1578 , paid tribute to de 
Vere as a prolific poet, and one whose "countenance shakes spears [24]." Why the strange reference to the Shakespeare-Pallas Athena pseudonym once again?

\section{Gray's Inn Law School}

A number of Shakespeare contenders are known to have attended Gray's Inn Law School, including the Earl of Derby, Sir Francis Bacon, the Earl of Oxford, etc. However, one important point has to be made here and that is that Francis Bacon was the Queen's illegitimate son, as Alfred Dodd has shown quite convincingly in the documentation, letters and other evidence provided in Francis Bacon's Personal Life Story. But that is not all. Edward de Vere was Francis Bacon's half-brother, and not only attended the same law school, but was also an illegitimate son of Queen Elizabeth I, as Paul Streitz provides evidence for and proved quite handily in Oxford: Son of Queen Elizabeth I. This makes the fact that the first play, $A$ Comedy of Errors - premiering and being performed at Gray's Inn-so significant, as it is not an institution that would be open to the likes of a commoner of the stripe of Will Shakspere. In fact, he would not be allowed in the front door without being escorted back out the door by his hands and legs as a lowborn guttersnipe who had no business being in those lordly halls. It is a snob's argument, but snobs they were, and anyone who argues differently just doesn't know England. In fact, very little has changed to this day regarding the evils of the class system and its attendant snobbery. This author should know, living there for five years, as a low-life commoner, and worse still, colonial.

What we do know is that the Earl of Oxford's father acted as a patron to a company of players. We also know that his adopted "changeling" son, Edward de Vere, the 17th Earl of Oxford, was involved with theatrical groups, not only as a student of Gray's Inn, but at the Court as well and later ran his own company of players [25]. A Comedy of Errors and Love's Labour's Lost are recorded as having been performed by the Lord Chamberlain's Company of players at Gray's Inn Dining Hall for the first time. There is a record showing A Comedy of Errors being performed on Innocent's Day, December 28 at Gray's Inn. Will Shakspere of Stratford could not have attended Gray's Inn Law School even if he wanted to, due to his lack of peerage and common roots.

Edward de Vere's younger half-brother, fellow illegitimate and changeling son of Queen Elizabeth I, Francis Bacon, was born January 22, 1561. As a boy, Francis was an exceedingly precocious child prodigy. The inscription on Hilliard's portrait of him reads, "O that I could but paint his mind." At the age of only 12, he was admitted to Cambridge University, but did not stay to complete his studies. He was put off by the system of philosophy taught there, which drove him out at age 15 . He then spent three years on the Continent, refining his French, Italian and Spanish, while familiarizing himself with the manners, customs and habits of the people of southern Europe. He returned home in 1579 to find that his father by adoption - since Francis was actually the Queen's concealed illegitimate son and ward of the Court-had passed away without leaving any provision for him in his last will and testament. He was compelled to study jurisprudence at Gray's Inn, which he pursued reluctantly. He protested to his uncle, then prime minister of England, that he had bigger ambitions for his life. He was anxious to pursue the literary arts, a pursuit he felt more suited for than the law profession or a life in politics and affairs of state.

He was not alone, of course. His half-brother, Edward de Vere, proceeded him in pursuing studies at Gray's Inn. There he caroused with the brightest wits of the day. Writing revels and play acting were a great pastime at Gray's Inn. It had a long history of staging plays for the cultivation of art and learning to offset the stifling atmosphere of law studies. There is no doubt that he was engaged in participating in theatrical revels. The question to ask is, did Bacon write all these early Shakespeare plays? It was 1579 , when these dramas began to materialize. He was only 18 years of age at the time; Will Shakspere was only 15 . The latter can be disqualified as he never studied at Gray's Inn and wouldn't be admitted to those lofty halls of learning even for a visit because of the class snobbery so pervasive at the time. In contrast, older half-brother, Edward, would have been over a decade older at 29. He would still be attached to Gray's as an alumnus, and would have probably participated in the revels and most probably collaborated in the writing of these plays.

Edward de Vere attended Gray's Inn in 1567 at age 17, after graduating from Oxford with a master of arts at age 16, and from Cambridge with a bachelor of arts at age 14. Francis was admitted as a student of Gray's in 1576 and called in 1582. In 1586, he was elected one of the Inn's first Benchers, rather than a reader, although he did hold readings in 1588 and 1600 . He was elected Treasurer of the Inn in 1608 and held the position until 1617, when he was appointed Lord Privy Seal. Throughout his time at Gray's, Sir Francis contributed several masques to the law society. He wrote parts of the Gesta Grayorum, presented on January 3, 1595 as part of the Christmas festivities. In James I's reign, Bacon was involved in preparing a masque, The Masque of Flowers, to celebrate the marriage of the king's favorite Robert Carr, the earl of Somerset, to Francis Howard. John Manningham, himself a student of one of the Five Inns of Court called the Middle Temple, saw a performance of Twelfth Night in 1601. Clearly, the plays were distinguished enough to find an audience among students of the noble class studying law at the Inns of Court. This suggests that the author was affiliated with the Inns of Court either as a student or alumnus. He certainly would have had to have been a nobleman for his plays to have been 
considered fit entertainment for a student body of such illustrious pedigree. Whether or not he could have attached his name to such plays, knowing the attitude of the noble class to peers lowering themselves by performing in or writing drama is debatable. It may not have been possible to take open credit for the plays.

Edward de Vere was born in 1550 in the country in secret and handed over as a changeling child to the recently wedded 16th Earl of Oxford, John de Vere, to raise as his own. Edward was educated at Queen's College, Cambridge and also studied law at Gray's Inn. At a young age, de Vere traveled around Europe, visiting France, Germany, and Italy. He was as widely travelled as his half-brother, as versed in the same European languages, and as apt a candidate for the Bard title. Oxfordians, those who believe Edward de Vere to be the author of the Shakespeare's plays, point to these travels as evidence of de Vere's worldly background, and fascination with all things Italian as the plays themselves seem to demonstrate. Other evidence often attested to is the amount of literary praise lavished on de Vere, despite only a few of his poems surviving under his own name.

Why was the Bard so inspired by Pallas Athena that he chose to adopt her nickname? From whence did this influence arise? It is known that, while studying law at Gray's Inn, the young Francis Bacon formed there a secret literary society called "The Honourable Order of the Knights of the Helmet." The "Helmet of the Order" was of course the helmet of Pallas Athena, the helmet that occulted her and rendered her invisible. She was Francis Bacon's patron goddess since his early experience with the French Academie on the Continent, whose patron was Pallas Minerva, the same goddess under her Roman designation. The candidate for initiation within the order swore allegiance to Pallas Athena and to uphold her ideals, banishing the serpent of ignorance to the remotest corners of the civilized world in order to spawn an age of enlightenment and a literary renaissance capable of enlightening the world. The initiate would then kiss the helmet, after which it was placed on his head. Just as the Helmet of Pallas was said to make the wearer invisible, so the initiate would become an Invisible of Bacon's Invisible College or mystery school and secret literary society. In his right hand, there was simultaneously placed the spear of Pallas, which he was sworn to shake with valor at all the serpents of ignorance and vice to be found in the world [26]. The Shakespeare plays appears to have been a collaboration between concealed Tudor prince Francis Bacon and his half-brother, illegitimate Tudor prince, Edward de Vere, who staged the plays as Lord Chamberlain (official in charge of Court theatrical productions) on his half-brother's behalf. Members of the secret fraternity would have worn the helmet of Lord Bacon's Invisibles within the Order and would have been sworn to write in secrecy. Given the political import of many of the plays including, Hamlet, Macbeth, Othello, Richard II, and Romeo and Juliet, the author would have been forced to write under a pen name and conceal his authorship. Shake-speares Sonnets - how the title actually appeared in the first edition of the poetry collection-also had to be written under a pseudonym, since they contained the story of the author's invisible or secret life. The hyphenation of the surname shows that it is a pen name derived from Pallas Athena, the goddess of the Greek theater known as the Spear-shaker.

The illustrious group of literati, Francis Bacon's team of "Good Pens," were recruited from Oxford and Cambridge, and were also known as "The Wild Goose Club." The latter name was chosen because the search for the authorship of works conceived and executed by this illustrious body was meant to be a "wild goose chase." What other purpose could the extended dialogue between Mercutio and Romeo serve in Act II, scene iv of Romeo and Juliet than to make a pointed reference to an inside joke of insiders of a secret writing guild or propaganda ministry referred to repeatedly through illusions to the "wild goose"?

\section{BLOCK QUOTE BEGINS}

Mercutio: Nay, if our wits run the wild-goose chase, I am done; for thou hast more of the wild goose in one of thy wits than, I am sure, I have in my whole five. Was I with you there for the goose? Romeo: Thou wast never with me for anything when thou wast not there for the goose.

Mercutio: I will bite thee by the ear for that jest.

Romeo: Nay, good goose, bite not!

Mercutio: Thy wit is a very bitter sweeting; it is a most sharp sauce.

Romeo: And it is not, then, well served in to a sweet goose?

Mercutio: O, here's a wit of cheveril, that stretches from an inch narrow to an ell broad!

Romeo: I stretch it out for that word "broad," which added to the goose, proves thee far and wide a broad goose.

(Romeo and Juliet, 2.4.75-91)

\section{BLOCK QUOTE ENDS}

A reference to "wild goose chase" occurs in the opening volley in this exchange, an illusion made by Mercutio. As with most Shakespeare plays, the characters in Romeo and Juliet are based on actual persons of note then living in England, who are simply granted fictional names in order to avoid direct references that might prove libelous or politically problematic. Mercutio as a character probably represents a fellow member of the writing guild and fraternal order, very probably Ben Jonson, or a "brother" of like ilk. The wild goose chase is initiated by the "Wild Goose Club," Francis Bacon's secret writing ministry spawned by HMSS, which he and his brother by adoption, Anthony Bacon, co-founded. For 
those who are unaware of the history, Alfred Dodd's much lauded biography of Francis Bacon, Francis Bacon's Personal Life Story, reveals that Francis Bacon is Queen Elizabeth I's concealed prince and changeling child. This is deeply significant as it establishes a link between Francis Bacon and Edward de Vere, since Paul Streitz's book, Oxford: Son of Queen Elizabeth I, contends that Oxford is another concealed prince of the Queen, making the pair half-brothers, since their mother, the Queen, conceived them by different fathers, Thomas Seymour in the case of de Vere, and Robert Dudley in the case of Francis Bacon. This would also explain why Oxford and Bacon joined forces in the writing and staging of the Shakespeare plays.

The visor of invisibility Pallas Athena drew down over her helmet to render herself invisible makes sense of an otherwise obscure scene from Act V, scene $\mathrm{i}$ of Henry IV, Part II, in which Davy speaks of one William Visor to his master Justice Shallow, a name of obvious allegorical import: "I beseech you, sir, to countenance William Visor of Woncot . . " (Henry IV, Part II, 5.1.38,39) To this entreaty, Shallow replies, "There is many complaints, Davy, against that Visor. That Visor is an arrant knave, on my knowledge." (5.1.40-42) "Woncot" is a probable allusion to Wincot. Wincot is where Will Shakspere's uncle and aunt lived and is clearly a name of Warwickshire designation. The gratuitous exchange has no relevance to the play and makes no sense at all unless it is to point to Will Shakspere of Stratford as the "visor" of Pallas Athena's helmet behind which the true author of the plays could remain obscured [27]. In other words, Will Shakspere from Stratford is the frontman behind which the true collaborators-Edward de Vere and Francis Baconcould conceal their roles in the writing and staging of the Shakespeare plays, out of political and social necessity. To substantiate the point, the Earl of Oxford's wife died in 1612. In her last will and testament, she stipulated that a certain sum be laid aside as a provision "to my dombe man." Was this the continuance of an allowance to be paid to the Stratford man, Will Shakspere, to maintain his role as the frontman? [28]. He certainly was mute in terms of composition and functioned as a kind of "dummy" of the real Bard, a mere stand-in or double.

According to Bacon biographer, Alfred Dodd, Francis Bacon wrote under many masks including, Thomas Nashe, Thomas Watson, Robert Greene, John Lyly, and William Shakespeare. In fact, amazingly, if it can be believed, Dodd claims that even Edmund Spenser was another mask employed by Bacon. According to Dodd, it was in July 1580 that a clerk, who worked for the Earl of Leicester, named Edmund Spenser, left to take up a job in Ireland. Before he left, Francis paid him for the use of his name in the publication of certain writings [29]. According to Dodd, John Lyly is just one of the masks under which Francis Bacon wrote secretly. Using the initials I.L., since the author of John Lyly's work often signed himself Ihon Lillie, the author wrote a commemorative poem about Edward de Vere. While there is no doubt that Bacon orchestrated many of these covert operations, including the effort to conceal the authorship, this does not mean that all of the invented personages and pen names are strictly his and for the purpose of serving as his own personal disguises. For heaven's sake, the man was in charge of an intelligence service. This would have required disguises for many of the Invisibles. On the contrary, they were inventions of the writing guilds spawned by his HMSS to conceal the true names and identities of the team of good pens who were to remain the Invisibles, his half-brother Edward de Vere being but one of the illustrious "Wild Goose Club," while still being a patron and paramount member of the guild.

It must be remembered that it was common practice in the age of Elizabeth for authors to suppress their names and substitute initials or a pen name [30]. This probably resulted from the fact that Elizabeth had enforced such strict censorship laws and meted out such severe penalties on violators. The author of the poem here in question attributes the valor Edward de Vere exhibited in the naval battle against the Spanish Armada to the inspiration provided by his patron goddess, Pallas, whom he refers to by name:

\section{BLOCK QUOTE BEGINS}

De Vere, whose fame and loyalty hath pierced

The Tuscan clime, and through the Belgike lands By winged Fame for valour is rehearsed,

Like warlike Mars upon the hatches stands,

His tusked Boar 'gan foam for inward ire,

While Pallas filled his breast with warlike fire [31].

\section{BLOCK QUOTE ENDS}

It seems rather odd that Pallas Athena, patron goddess of the Greek theatre in Athens and goddess of wisdom sprung from the brow of Zeus, should be placed on board Edward de Vere's ship at the time of battle. One could imagine the goddess of war or some other goddess being at his beck. Why of all goddesses it should be the goddess of the Greek theater inspiring him in time of battle is extremely odd, unless of course Lyly, or Bacon, since Lyly was a Baconian mask, knew Pallas was de Vere's patron goddess. If de Vere's patron goddess was Pallas Athena, then it would not be surprising for him to borrow her attributes, since it was custom for noblemen to employ pen names to conceal their authorship at this time in history. It must be remembered that the nobility seldom attached their names to works of poetry and especially dramatic works, as it was considered beneath their dignity to publish lines of verse or plays.

Why would the Tudor princes Francis Bacon and Edward de Vere find the need to employ pen names? The threat of losing caste was so real for the author(s) of the Shakespeare plays that it is even 
alluded to in a poem by John Davies, a contemporary, appearing in the Stationer's register of 1610. The Stationers' Company-formed in 1403, and receiving its royal charter in 1557-held a publishing industry monopoly and was the entity officially responsible for setting and enforcing regulations. What becomes abundantly clear is that the entire poem is written in the past tense, which suggests that its import is addressed to a poet already dead. It is believed that Edward de Vere was already dead in 1610 . Orthodoxy ascribes his death to 1604 , though that is not the correct date as we will learn. Will Shakspere of Stratford, however, would not be referred to in the past tense in 1610, as he still had six more years of life in him. The other thing to notice about Davies's poem is the fact that the Will. Shakespeare referred to is most definitely of the noble class, which the Stratford man was most definitely not, and has lost his noble rank as a consequence of his having performed in his own plays, a definite no-no for a nobleman:

\section{BLOCK QUOTE BEGINS}

To our English Terence, Master Will. Shakespeare.

Some say (good Will) which I, in sport, do sing, Hadst thou not played some Kingly parts in sport, Thou hadst been a companion for a King;

And been a King among the meaner sort.

Some others rail; but, rail as they think fit,

Thou hast no railing, but, a reigning Wit:

And honestly thou sowst, which they do reap;

So, to increase their stock which they do keep [32].

\section{BLOCK QUOTE ENDS}

The import of the poem is that "Shakespeare"- the name once again appearing hyphenated, indicating it is a pseudonym - is a nobleman who lost rank by performing on the stage. So addicted was he to performing that he would take to the stage secretly under his pen name, but was probably recognized by the Queen's omniscient secret service and reported. "Thou would have been a companion for a King" is an allusion to his status as an earl; the title "count" being equivalent to "earl" in the English caste system, is in fact designated as a "companion to the King" in terms of peerage. "And been a King among the meaner sort" refers to the fact that de Vere was actually a concealed royal prince, and had played kingly parts for the theater, which would in fact be seen as "a meaner sort of King," since the theater was considered low and common. There is, in fact, a well-known portrait of Edward de Vere extant, showing him in costume as King Henry. The last two lines of the poem indicate that the Bard labors without gain, since others profit from his work. The implication seems to be that certain individuals reap the benefits of his work and keep the profits for themselves. At the same time that a nobleman who has lost caste is implied, so an allusion is also made to the man from Stratford known as "Will Shakspere." The clue for this occurs in the allusion to "our English
Terence." The English Terence refers to the Roman poet Terence, a slave who became a free man and a well-known poet. The man summoned from Stratford to act as the frontman and to double as the Bard, in order that the true author could conceal his authorship of the plays is here implied. It is well documented that the frontman from Stratford did draw an annuity, which made him well-placed to purchase the largest estate home then in Stratford called New House.

To corroborate the above account, where a tribute is given to an author already dead, when the man from Stratford is still living, we have the first edition of the sonnets published in 1609 under the title, Shakespeares Sonnets. Once more the name appears hyphenated implying a pen name, but there is something else this time. This kind of locution is usually reserved for one who is already dead. The byline should read, "By William Shake-speare" for a living author. Then, there is the text of the dedication, which refers to "our ever-living poet," implying once again that the author is no longer living. "Ever-living" is used in memorials to signal the fact that someone dead lives on in the memory of the living [33].

Is the Elizabethan social ethos and the question of caste the only issue? Are there other reasons for adopting a pen name? The fact is that Edward de Vere would have a very good reason for adopting a code name were he a spy or agent of the British Crown. And the evidence strongly supports the fact that he was, the most convincing being his status as a secret agent can be found in a Privy Seal warrant issued by the Queen on June 26, 1586. The warrant calls for a grant to be issued to the Earl of Oxford to the tune of $£ 1,000$ a year, a sizeable sum equivalent in today's terms to three times the prime minister's salary. The reason for the grant is not given, but what is abundantly clear is that the Queen issues instructions at the end of the letter that no accounting for the expenditure is required by the Exchequer, standard practice in the case of secret service money:

\section{BLOCK QUOTE BEGINS}

Elizabeth, etc., to the Treasurer and Chamberlains of our Exchequer, Greeting. We will and command you of Our treasure being and remaining from time to time within the receipt of Our exchequer, to deliver and pay, or cause to be delivered and paid, unto Our right trusty and well beloved Cousin the Earl of Oxford or to his assigns sufficiently Authorized by him, the sum of One Thousand Pounds good and lawful money of England. The same to be yearly delivered and paid unto Our said Cousin at four times of the year by even portions: and so to be continued unto him during Our pleasure, or until such time as he shall be by Us otherwise provided for to be in some manner relieved; at what time Our pleasure is that this payment of One Thousand Pounds yearly to our said Cousin in manner above specified shall cease. And for the same or any 
part thereof, Our further will and commandment is that neither the said Earl nor his assigns nor his or their executors nor any of them shall by way of account, imprest, or any other way whatsoever be charged towards Us, our heirs or successors. And these Our letters shall be your sufficient warrant and discharge in that behalf. Given under Our Privy Seal at Our Manor of Greenwich, the six and twentieth day of June in the eight and twentieth year of Our reign [34].

\section{BLOCK QUOTE ENDS}

What the last two sentences mean is that no accounting of expenditures implied by the grant are to be required by the Exchequer, which is tantamount to saying that the transaction is secret and classified. The Oxfordian scholar, Bernard Mordaunt Ward, claims that this is the usual formula followed in the case of secret service money. The Earl of Oxford had no known office other than his place on the Privy Council, so there is no good reason for the payment in terms of official function or capacity. There is no evidence of any official assignment calling for such an annuity. The earl never left the country following the issuance of the grant which he received beginning in 1586, when he was 36 , until the time of his 'alleged' death in 1604, at the age of 54 [35].

For so large an amount to be paid out of the secret service fund, it had to have been used for purposes of state, arguably for England's first formally inaugurated ministry of state propaganda. The purpose of the propaganda ministry would be to school the English people, most of whom could not read, through a medium of education analogous to today's Hollywood, opening their eyes to the world around them, while acquainting them with a revisionist history that would have them bursting with pride. And while the state was busily taking charge of the theater for purposes of social engineering through propaganda, it was simultaneously clamping down on the printing presses, the Queen authorizing Archbishop of Canterbury John Whitgift and the Privy Council to draft legislation to strictly regulate them. A Star Chamber decree was duly authorized on June 23, 1586 calling for stricter governance over the printing press, with a list of pains and penalties for violations of the censorship laws. No publication could be released without first receiving approval from the Archbishop of London. The success of the Queen's propaganda ministry cannot be underestimated for its power to instruct the uneducated masses on their history, enlightening them on their place, and furnishing them with so thorough a knowledge of rewards and punishments, they would have known what would invite praise and censure. A more vivid description of the propaganda apparatus the theater guilds served could not be found than in Thomas Heywood's aptly named Apology for Actors, which is none other than a defense for the theater arts being held subordinate to the state to which the performers themselves had been ransomed:

\section{BLOCK QUOTE BEGINS}

Plays have made the ignorant more apprehensive, taught the unlearned the knowledge of many famous histories, instructed such as cannot read in the discovery of all our English chronicles; and what men have you now of that weak capacity that cannot discourse of any notable thing recorded even from William the Conqueror, nay from the landing of Brute, until this day? Being possessed of their use, for or because plays are writ with this aim, and carried with this method, to teach their subjects obedience to their king, to show people the untimely ends of such as have moved tumults, commotions, and insurrections, to present them with the flourishing estate of such as live in obedience, exhorting them to allegiance, dehorting them from all traitorous and felonious stratagems [36].

\section{BLOCK QUOTE ENDS}

Is it mere coincidence that history plays remained in vogue from 1586 until the conclusion of the Anglo-Spanish War (1585-1604)? Chronicle plays were very popular, William Shakespeare (BaconOxford mask), John Lily (Bacon mask), and Thomas Kyd (Bacon mask) wrote several, many of which were original, but some of which the Tudor princes apparently permitted their apprentices to revise and reshape. At the cessation of the war, the demand for such plays from the state and the appetite for them from a people weary of war dried up. Considering how scarce money was at the time, and how careful the Queen had to be with funds in providing for the war effort, it is clear that, if not the Queen, the state apparatus, had to be sufficiently pleased with the propaganda produced for the Elizabethan stage to maintain Lord Oxford's annuity as the Lord Chamberlain until the time of his death.

Why would the earl receive such an annuity? If he is not being paid for his official duties, what is the reason for so exorbitant a salary? Is he being paid for covert operations of some kind? Once again, the evidence would support such a hypothesis. Christopher Marlowe and Ben Jonson both faced prosecution for libelous and blasphemous allusions made in their plays, great risks for commoners to take without protection from higher personages, institutions or organizations. In May 1593, the Star Chamber prosecuted Christopher Marlowe for "lewd libels" and "blasphemes." Certain papers of Thomas Kyd were found keeping company with Marlowe's manuscripts. Testifying under duress on the rack, Kyd protested that, "My first acquaintance with this Marlowe rose upon his bearing name to serve my Lord, although his Lordship never knew his service, but in writing for his players." It is one of the most tantalizing mysteries in the Marlovian biography question that Kyd omits to identify the mysterious lord of whose household he had been a member for nearly six years. Six years would place Kyd in the services of the mysterious lord back to the end of 1587 , from his time of arrest in 1593. The Spanish Tragedy attributed 
to Kyd on the strength of a single reference, is assigned by scholar Edmund Gosse to the period 1584 to 1586 . Researcher E.T. Clark believes that the mysterious lord under whose supervision Kyd worked for six years, and for whose players Marlowe wrote, was none other than Lord Oxford [37]. However, it is also known that Lily was employed as the secretary of Lord Bacon. This period of employment just happens to coincide with King Philip II of Spain's rage over the manner in which he was portrayed on the Elizabethan stage. The Venetian ambassador of Spain even reported on King Philip's complaints concerning the Elizabethan stage to the Signory:

\section{BLOCK QUOTE BEGINS}

But what has enraged him much more than all else, and has caused him to show a resentment such as he has never displayed in all his life, is the account of the masquerades and comedies which the Queen of England orders to be acted at his expense [38].

\section{BLOCK QUOTE ENDS}

What King Philip's complaint — as related by the Spanish ambassador-makes explicit is the fact that the plays had some effect in rousing a reaction from the foreign courts. It is at this time that we begin to hear about the so-called "university wits." Researcher E.T. Clark believes that Oxford's apprentices turned out dozens of plays under his supervision, including chronicle plays, revenge plays, Senecan plays, most of them conceived to sustain the people's morale during wartime. Since his early twenties, Oxford had served as a patron for other writers, so it was easy for him to slip into his new role as the master of young propaganda initiates [39]. Clark maintains that Oxford turned to recent graduates of Cambridge and Oxford, and even to those at the point of graduating, who showed promise as writers, to assist in the task of writing state propaganda for the stage. Clark also contends that it was Oxford who discovered Marlowe's dramatic gifts, encouraging him to write Tamburlaine to portray as a ruthless conqueror the personage of King Philip II of Spain [40].

According to the great Baconian scholar, Alfred Dodd, in 1579 and by 1580, Sir Francis Bacon had founded the secret literary societies Fra Rosi Cross and The Honourable Order of the Knights of the Helmet, the latter named in honor of his patron goddess Pallas Athena who always wore the 'helmet of invisibility.' This was all part of Bacon's effort to achieve "The Universal Reformation" or English Renaissance in literature. Fra Rosi Cross and The Honourable Order of the Knights of the Helmet were invisible colleges or mystery schools, whose initiates wore Pallas Athena's helmet of invisibility and were known as Invisibles. The founding of these societies began at Gray's Inn Law School, the Grand Patriarchs of the orders being Bacon's personal friends such as Gabriel Harvey, his old literary professor, and Fulke Greville, a well-known poet. Bacon's cousin, Sir Philip
Sydney, and Sydney's sister, Lady Mary, Countess of Pembroke, would also be on the planning committee. And according to Dodd, "He would have the warm support of Edward de Vere, Earl of Oxford, also a poet [41]." Was Oxford a poet or a concealed poet, one of the Invisibles? Dodd has provided strong evidence that Oxford and Bacon were associates and that he was even in on the planning of these invisible literary societies. Was he also a member? It is very likely. He was referred to as a poet and playwright and yet he stopped writing poetry at least under his own name at a very young age, while strangely none of his plays survive under his real name.

Jonson, Marlowe, possibly Lord Oxford and others were working together as a syndicate of writers under the patronage of Sir Francis Bacon, whose source of funding came from the Queen, which is one explanation for the great flowering that occurred in Elizabethan drama and the unity of style found among the major playwrights of the time. Similarities found between the Shakespearean and Marlovian works, which have hitherto been explained away by charges of plagiarism and even the speculation that Marlowe was covertly writing the Shakespeare plays, can now find a more logical explanation. What is more likely is that the similarities in styles found among the playwrights resulted from them working closely together as part of the same secret literary guild and propaganda ministry, writing and sometimes sharing plays to meet deadlines assigned to them either by Bacon's propaganda ministry or the Court. Similarities found between Shakespeare's early historical dramas and Marlowe's Edward the Second, published in 1594 as Marlowe's, which orthodoxy acknowledges as proof of the greater author's debt to the lesser, can instead be explained by the reverse scenario, in which Marlowe, as an initiated member of Fra Rosi Cross, was most likely apprenticing under the Tudor princes Bacon and de Vere, the author(s) known to posterity as William Shakespeare [42]. Bacon does in fact state in his embedded cipher biography that he wrote and published plays under Marlowe's name following his death, employing the name Christopher Marlowe as one of his many pseudonyms. In the embedded cipher code message, discovered by Elizabeth Gallup, concealed in Francis Bacon's work Of the Advancement of Learning, we learn about the many pseudonyms he employed:

\section{BLOCK QUOTE BEGINS}

My stage places have all been isguise'd (to sit, many in Greene's name or in Peele's, Marlowe's, a fewe, such as the Queene's Masques and others of this kind published for me by Jonson, my friend and coworker) since I relate a secret history therein, a store of so sterne and tragick quality, it illie suited my lighter verse, in the earlier works [43]. 


\section{BLOCK QUOTE ENDS}

\section{Shakespeare Algorithm}

The authors of the Shakespeare study called the "Shakespeare Algorithm," pulled their data from Massachusetts Institute of Technology's online repository of Shakespeare's works. The 37 plays that constitute the official canon are available in Hypertext Markup Language (HTML) — computer language used to create web pages-format, which the researchers then ran through a high-level programming language to remove the HTML tags, stage directions, and character names that appear before the spoken lines. The works were then loaded into $\mathrm{R}$ - a programming languageusing the $t m$ text mining library and run through a stemming and stopword removal algorithm as well as a conversion algorithm to map all characters to lowercase. A collection of five poems and a number of sonnets were taken from a different website, but were also normalized into a single text file in like fashion. The prime candidates, whose works were examined in the study, as alternative candidates for the Shakespeare authorship were Bacon, Marlowe, and de Vere. Each of these candidates have works under their own names available online, which were also put though a similar normalizing procedure and used in the study for sake of comparison with the plays.

The first Shakespeare candidate to be examined by the authors of the study was Marlowe. Born in Canterbury in 1564, the son of a shoemaker, he was fortunate to receive a scholarship to attend both King's School Canterbury, as well as Corpus Christi College, Cambridge. At Corpus Christi College, he practiced translations, poetry, and playwrighting. He is thought to have been killed in 1593, a fact denied by Marlovians, who believe he went into exile and continued to write plays under the pen name William Shakespeare. Marlowe's works published before 1593 allow for the hypothesis that Marlowe was Shakespeare to be tested through a comparative analysis with the Shakespeare works. Plays by Marlowe used in the analysis include Dido, Queen of Carthage, Tamburlaine Part 1, Tamburlaine Part 2, The Jew of Malta, and Edward II.

\section{Character Distribution}

The character distribution analysis is based on identifying differences in style between authors by determining the probability that one of the authorial candidates uses a given character. The basic algorithms are designed to determine the relative probabilities that every unique character found in a work contains, and then average those probabilities over each character for each work by a given author. In Marlowe's case, there are significant differences in the usage of certain letters. Marlowe tends to use the vowel " $e$ " far more often than the author identified as "Shakespeare." It also appears that Marlowe uses more spaces in his work, which could imply that he tends to use shorter words.
H0 - the null hypothesis - in this case is that given the relative probabilities and variances of each character appearing in either author's work, what is the probability that both bodies of work share the same source? Table 1 shows the output of the R code, which includes the average probability of each character appearing in both Shakespeare's and Marlowe's works as well as the difference and the z-score, the number of standard deviations from the mean data point.

Before even looking at the p-value-the level of marginal significance within a statistical hypothesis test representing the probability of the occurrence of a given event-for the $\mathrm{X}^{2}$ test, it is clear that, for the vast majority of characters, the probability of both values coming from the same normal distribution is almost zero. The $\mathrm{p}$-value on the $\mathrm{X}^{2}$ test confirms this suspicion, resulting in a rejection $\mathrm{H} 0$ in favor of $\mathrm{Ha}$-alternate hypothesis - as the evidence shows that the works by the author identified as "Shakespeare" and Marlowe do indeed come from different sources. Though there is a difference in the corpus size between the two authors, the amount of text confirmed to be authored by Marlowe is fairly substantial, so the results have some persuasive power.

\section{Word Length Analysis}

The authors of the study also chose to analyze the difference in word length distributions among the Shakespeare authorship candidates. For each author, they calculated the fraction of words that are a certain length. Specifically, they looked at words of length one to 19 letters, since anything beyond that would not be significant. They then calculated the average proportions for each word length found in the various author's works. Figure-2 shows the result of the word length study. One can immediately notice that Shakespeare used significantly more four-letter words than three-letter words, whereas Marlowe uses more three-letter words than any other. The authors of the study found that "Shakespeare" was one of the few authors that used more four-letter words than any other word length. The graph is a good way to understand data, but the $\mathrm{X}^{2}$ test for independence can reveal if the word length distribution between Shakespeare and Marlowe is significantly different. This test is shown below in Table-2. After running the test between the average word length distribution in 37 Shakespeare works and five Marlovian works, a p-value of 0.256 emerged. The authors of the study decided that they should go with the standard 0.05 cut off, which clearly shows that the distribution of Marlowe's word length usage is not significantly different from Shakespeare's.

\section{Proportion of Unique Words}

The vocabulary used in written works often varies from author to author. The study authors decided to look at the ratio of unique words in a work to the total number of words used. They averaged the ratios for each of the five works attributed to Marlowe and got 
an average ratio of 0.2073 with a variance of 0.0005 . The extremely low variance tells us that Marlowe was quite consistent in how many unique words he used in his works relative to the total number of words. They did the same thing with a set of Shakespeare's works. It is important to note here that the authors of the study had access to 37 works for Shakespeare, which is significantly more than the corpus for Marlowe. The average ratio of unique words to total words for Shakespeare was 0.16 with a variance of 0.0002 . Once again, the study authors found a very low variance, which gave them hope in using a calculated ratio to distinguish between Shakespeare, the 'real' Shakespeare, and other contemporaries. They clearly observed that Marlowe and Shakespeare have a significantly different writing style when it comes to vocabulary usage.

The second Shakespeare candidate to be examined for the Shakespeare authorship candidacy was Francis Bacon. He died in 1626, making him the only candidate to have lived throughout the entire span in which the Shakespeare plays, poems and sonnets were published. The works by Bacon that were selected for comparison to Shakespeare's plays include, The Great Instauration, Preparative toward a Natural and Experimental History, and The New Atlantis.

\section{Character Distribution}

The authors of the study used the same character distribution test as they had with Marlowe. The results are shown in Figure 3 with the $X^{2}$ test displayed in Table 4. A quick glance seems to confirm the same results as those found with Marlowe. Bacon used longer words (i.e. fewer spaces) than Shakespeare as well as significantly more usages of the letters " $t$ " " $i$ " and "e." It is not surprising that the $p$-value $=0$ for the $\mathrm{X}^{2}$ test given the differences illustrated by Figure- 3 . That means based on this one test, it is unlikely the works attributed to Bacon and Shakespeare came from the same source. However, this result also suffers from the same flaw as in the previous section. The number of Baconian works chosen for comparison is limited. In addition, the scholarly style of Bacon's works differs dramatically from the literary style of the Shakespearean canon.

\section{Word Length Analysis}

The comparison of word length distribution between Shakespeare and Bacon produced significantly different results compared to that of Marlowe. The graph of the word length distributions can be found in Figure-4.

The $\mathrm{p}$-value from our $\mathrm{X}^{2}$ test for independence is shown in Table 5 is $2.25 \mathrm{E}-7$. This is an extremely low p-value and lead the authors of the study to the conclusion that the word length distribution is significantly different between Shakespeare and Bacon. From this and other results found in the study, the authors decided that it is unlikely that Bacon authored the Shakespeare works.

\section{Proportion of Unique Words}

Analyzing Bacon's unique word usage compared to total word usage yielded very similar results to that of the Marlowe analysis as shown in Table-3. Bacon's average ratio was 0.2044 with a slightly greater value of 0.0012 . However, these values are grossly at variance with Shakespeare's 0.16 average ratio with a variance of 0.0002 .

\section{Character Distribution}

The test for character distribution is identical to that used in the previous sections. There is a difference though in terms of the corpus of data available for mining: Edward de Vere was a nobleman and thus it is conjectured that he did not publish plays under his own name, as it was not considered seemly for a man of his status. Thus, the only readily available works the authors of the study could find were 25 short poems attributed to him for a total of around 600 lines. Because poetry tends to have a different structure and style than prose (i.e. plays), it was not considered fair to compare de Vere's poems with Shakespeare's plays. The input to the character distribution test is then a collection of Shakespeare's poems and sonnets totaling around 1,100 lines. The results are presented below with Figure 5 plotting the relative probabilities and Table 6 showing the $\mathrm{X}^{2}$ test.

There are significant differences in the character usage between the two poets. Shakespeare tends to use fewer spaces (and thus longer words) than does de Vere, and seems to use a lot more punctuation. The $\mathrm{X}^{2}$ test shows fairly conclusively that the poems attributed to de Vere and Shakespeare came from different sources based on the character distribution test. But this test suffers the most in terms of corpus size. The study authors only had some 600 lines of poetry from de Vere compared to the 9,000 lines of prose (which tends to be longer) which they analyzed for Marlowe and hence the problem. Unless more surviving works from de Vere surface, there is really nothing to be done to improve accuracy.

\section{Word Length Analysis}

Lastly, an analysis was run on the word length distributions between Shakespeare's and de Vere's poems. In general, poems are significantly shorter than dramatic pieces, histories, and comedies. It is also well known that only approximately 25 of de Vere's works survive. However, the study authors still decided to run this test because they found a plethora of information online, leading them to believe that de Vere may have written under the pen name Shakespeare. The graph based on this comparison is shown in Figure-6. 
The results of the $\mathrm{X}^{2}$ test do not distinguish the works of the two authors very well. In this regard, there is strong evidence that de Vere remains a viable candidate as the true author of the Shakespeare plays. The p-value was 0.40 , a shockingly high number compared to the results from the previous section. Even though they did not have many of de Vere's works to analyze, this result, along with other statistics comparing Shakespeare to de Vere, led the study authors to conclude that the two authors may be the same person.

\section{Proportion of Unique Words}

The real surprise came when the study authors used their unique word ratio analysis to compare de Vere's works with Shakespeare's plays, the results of which are summarized in Table 8. It is important to note again that there is not a significant amount of work available written by de Vere. Nevertheless, they used a merging of a set of Shakespeare's works totaling approximately 8,300 words and a merging of de Vere's works totaling approximately 3,700 words. They determined that de Vere had a ratio of 0.31 and that Shakespeare had a ratio of 0.30 . These values are extremely close to each other and substantiate the result from the word length distribution comparison between Shakespeare and de Vere. The test results present the strong possibility that de Vere was Shakespeare.

\section{CONCLUSION}

Based on the study, it appears extremely improbable that the works attributed to William Shakespeare were written by either Marlowe or Bacon. However, the results of the Shakespeare-de Vere tests indicate that the Oxfordian camp may have the strongest case. The study authors were particularly intrigued by the connections between events in the Shakespeare plays and those of de Vere's life which abound. Though such personal connections cannot be scrutinized in a text-mining experiment, they do give greater weight to statistical similarities. Given more time the study authors would like to conduct a more extensive study of the vocabulary found in the Shakespeare plays and the vocabulary contained in de Vere's letters. Though indications exist online that such work has been done, it is difficult to find solid research about this subject.

In short, the research project leads the study authors to the conclusion that out of three usual suspects for the authorship, de Vere is the only candidate who shows serious potential. After noticing that de Vere also holds the most followers currently ascribing to the non-Shakespeare theory, the study authors are very doubtful that Shakespeare did in fact author the plays [44].

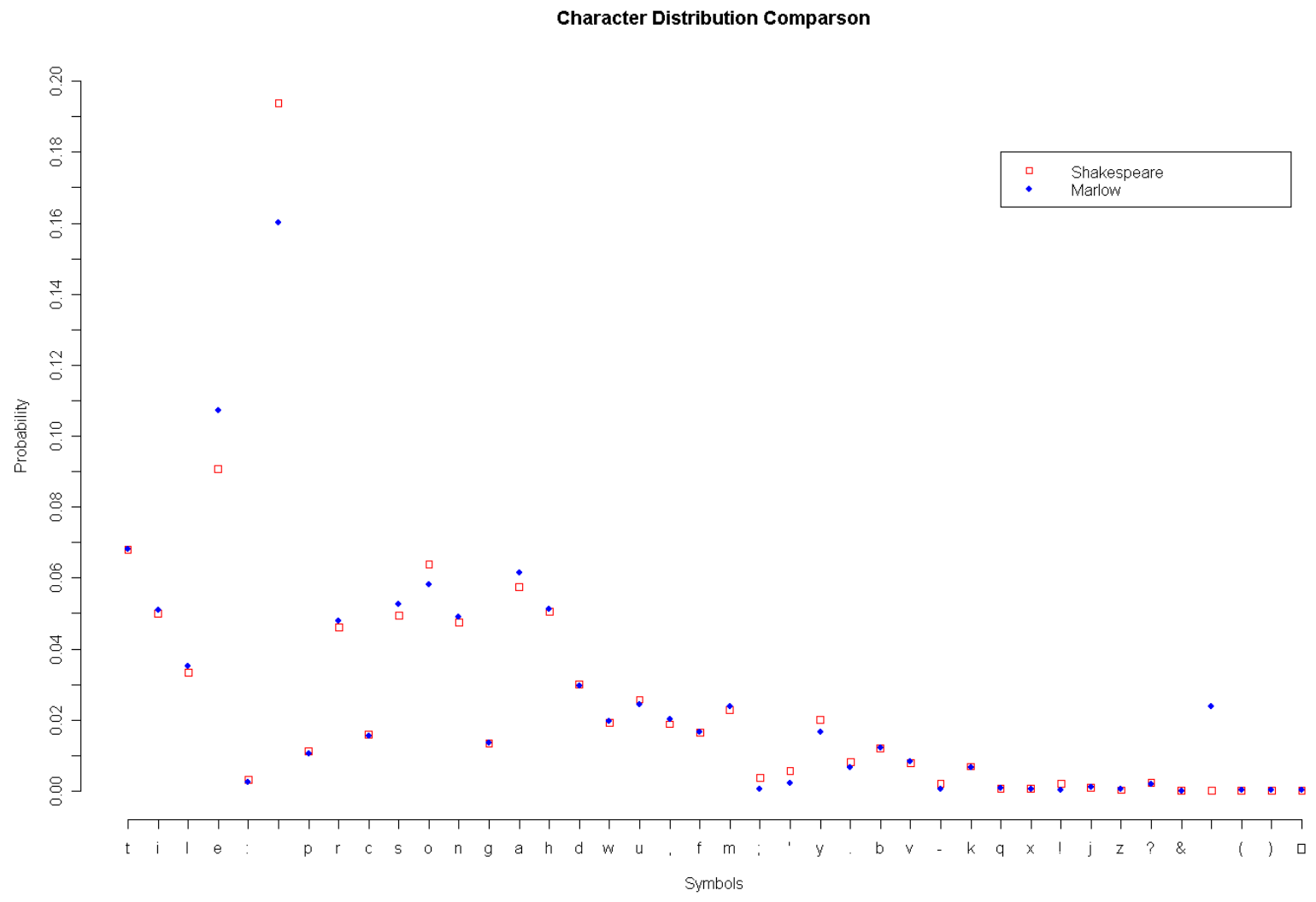

Fig-1: Character Probabilities: Shakespeare and Marlowe 


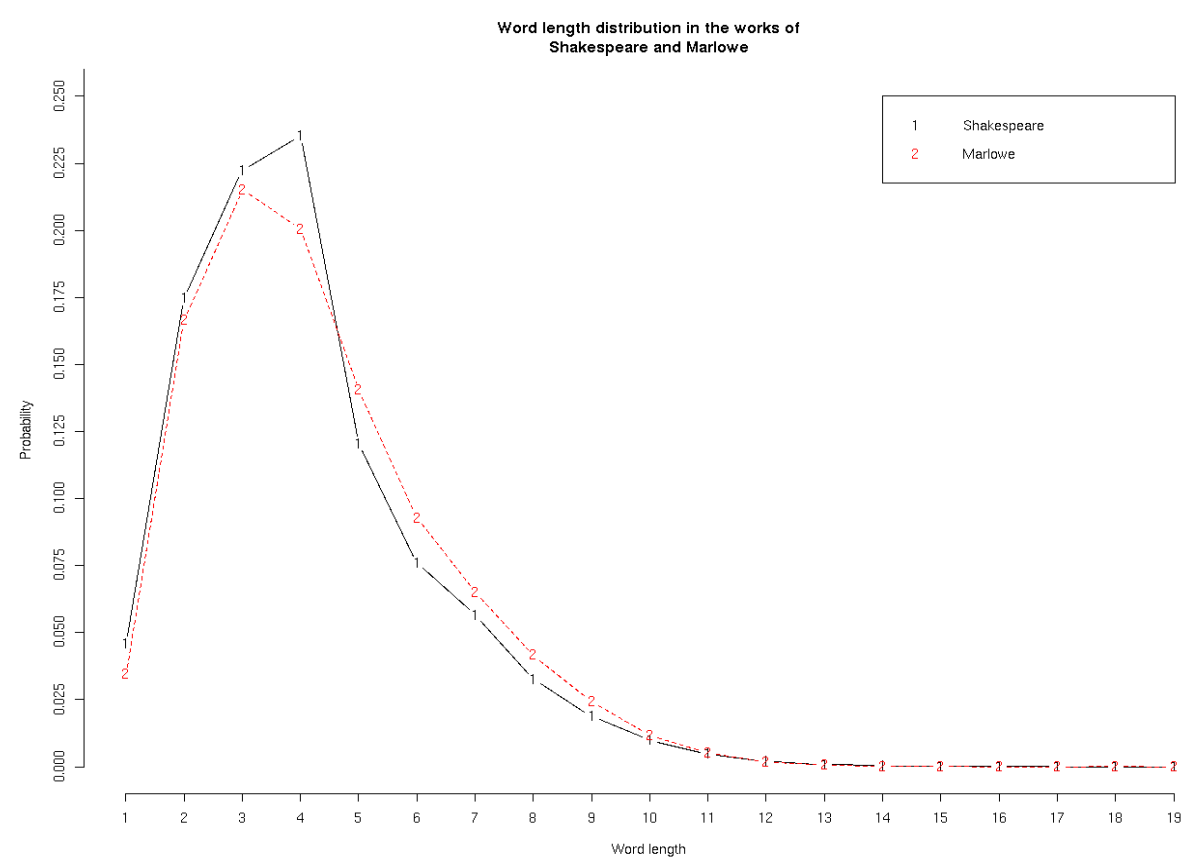

Fig-2: Average Word Length Probabilities: Shakespeare and Marlowe

Table-1: Character Probability Averages: Shakespeare and Marlowe

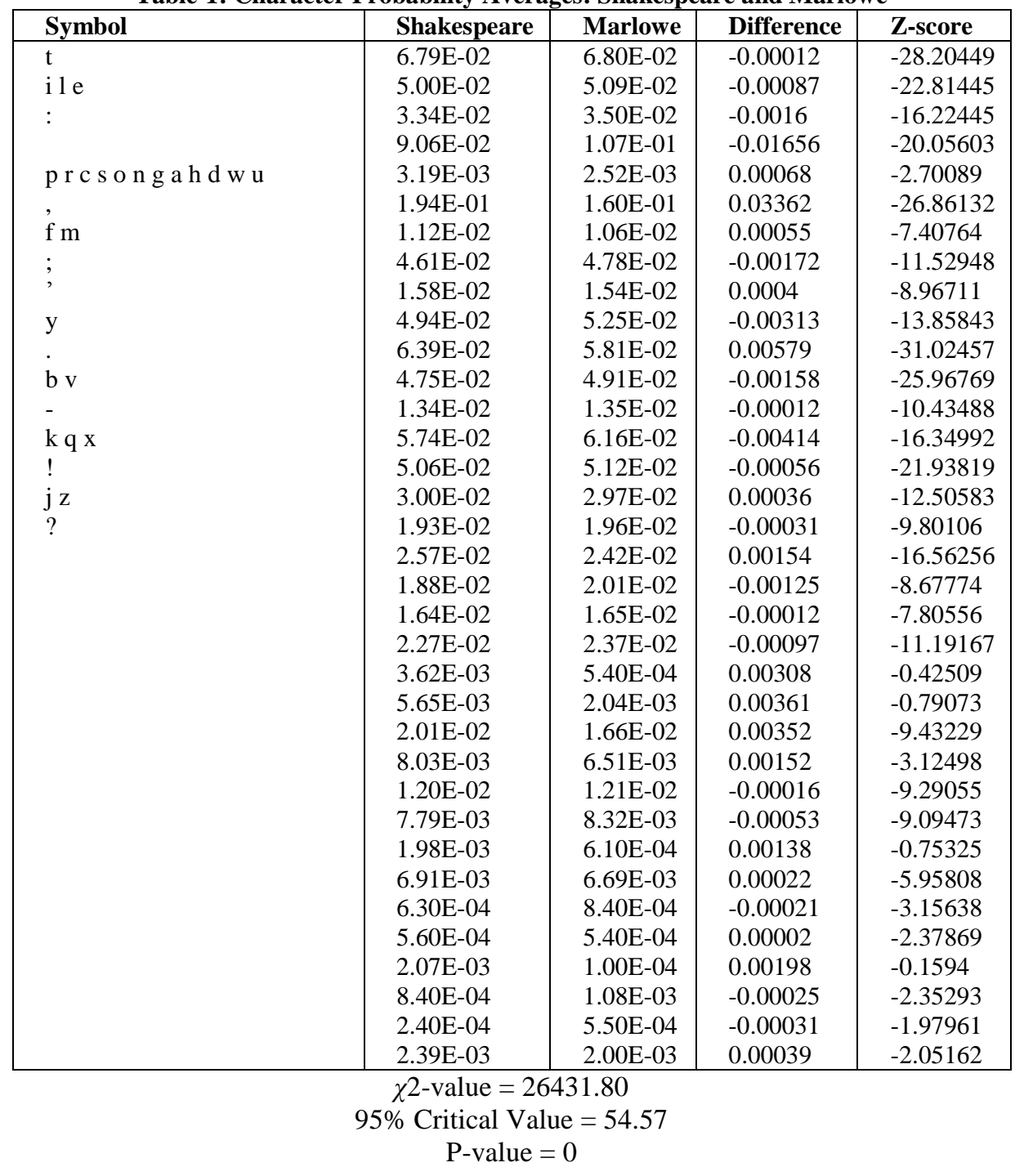


Table-2: Word Length Probability Averages: Shakespeare and Marlowe

\begin{tabular}{|l|l|l|l|l|}
\hline Length & Shakespeare & Marlowe & Difference & Z-score \\
\hline 1 & 0.0459 & 0.0344 & 0.0115 & 1.1627 \\
\hline 2 & 0.1747 & 0.1665 & 0.0082 & 0.7032 \\
\hline 3 & 0.2223 & 0.2152 & 0.007 & 0.5302 \\
\hline 4 & 0.2352 & 0.2005 & 0.0347 & 2.6684 \\
\hline 5 & 0.1203 & 0.1404 & -0.0201 & -1.7334 \\
\hline 6 & 0.0759 & 0.0928 & -0.0169 & -1.5402 \\
\hline 7 & 0.0565 & 0.0651 & -0.0086 & -1.1033 \\
\hline 8 & 0.0325 & 0.0416 & -0.0091 & -1.317 \\
\hline 9 & 0.0187 & 0.0244 & -0.0057 & -0.997 \\
\hline 10 & 0.01 & 0.0115 & -0.0016 & -0.3423 \\
\hline 11 & 0.0046 & 0.005 & -0.0004 & -0.1284 \\
\hline 12 & 0.0019 & 0.0017 & 0.0003 & 0.302 \\
\hline 13 & 0.0008 & 0.0008 & 0.0001 & 0.2094 \\
\hline 14 & 0.0003 & 0.0001 & 0.0002 & 0.8328 \\
\hline 15 & 0.0002 & 0 & 0.0001 & 1.0076 \\
\hline \multicolumn{5}{|l|}{$\chi 2$-value $=21.48$} \\
\end{tabular}

$95 \%$ Critical Value $=28.87$

$\mathrm{P}$-value $=0.26$

Table-3: Probability of Unique Words in Prose

\begin{tabular}{|l|l|l|l|}
\hline & Shakespeare & Marlowe & Bacon \\
\hline Variance & 0.0002 & 0.00005 & 0.0012 \\
\hline Mean & 0.16 & 0.20 & 0.20 \\
\hline
\end{tabular}

Character Distribution Comparson

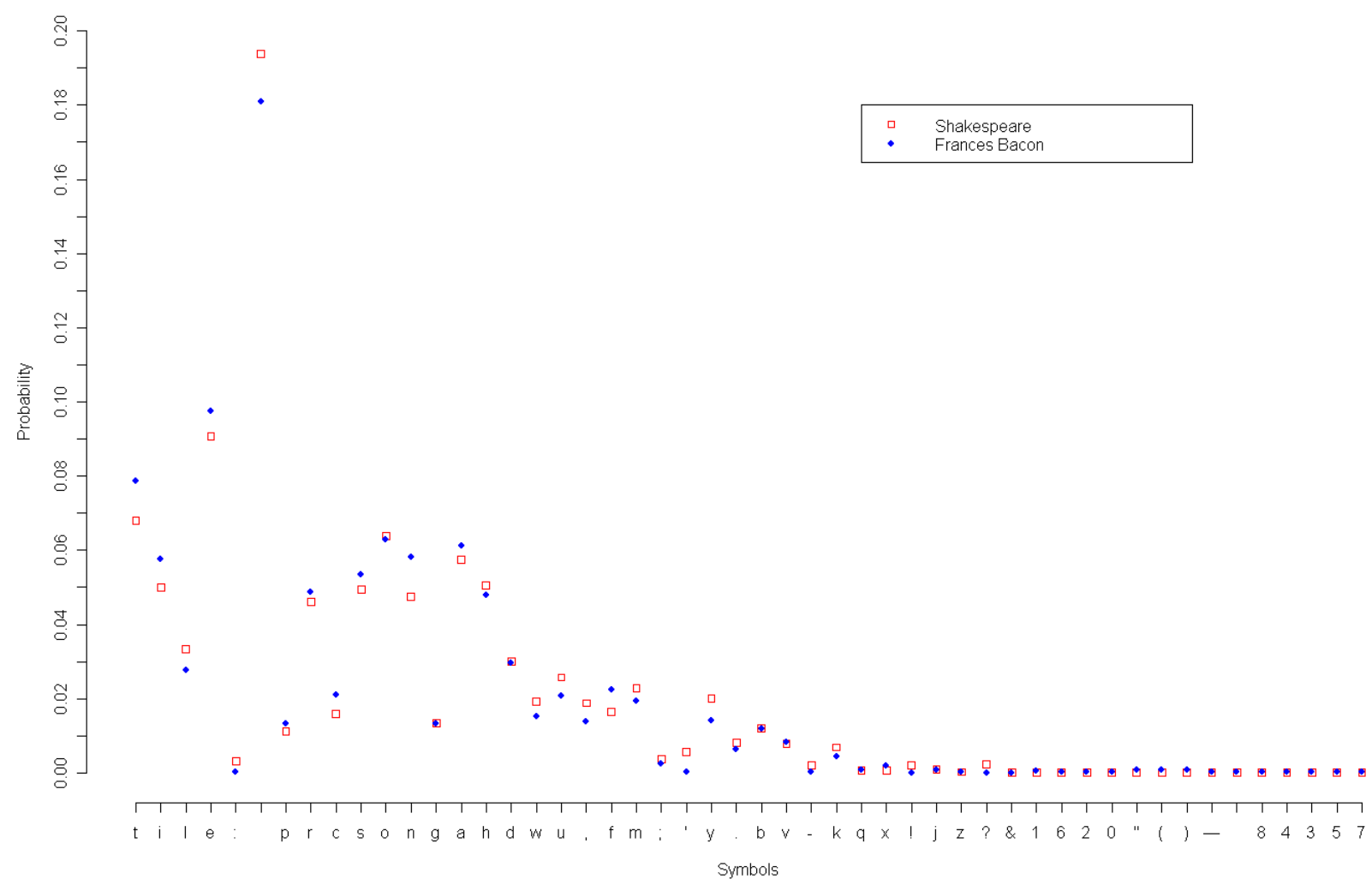

Fig-3: Character Probabilies: Shakespeare and Bacon 
Table-4: Character Probability Averages: Shakespeare and Bacon

\begin{tabular}{|l|l|l|l|l|}
\hline Symbol & Shakespeare & Bacon & Difference & Z-score \\
\hline t 1 e & 0.06791 & 0.0787 & -0.01079 & -18.92844 \\
: & 0.04998 & 0.0576 & -0.00762 & -10.30105 \\
p r c s o n g a h d w u & 0.03342 & 0.0276 & 0.00582 & -13.43811 \\
f m & 0.09064 & 0.09751 & -0.00687 & -24.49717 \\
$; ;$ & 0.00319 & 0.00025 & 0.00294 & -0.494 \\
y & 0.19374 & 0.18079 & 0.01295 & -42.86218 \\
b v & 0.01115 & 0.01338 & -0.00223 & -9.23132 \\
- & 0.04611 & 0.0487 & -0.00258 & -14.56877 \\
k q x & 0.0158 & 0.02088 & -0.00508 & -6.93951 \\
j z & 0.04941 & 0.05339 & -0.00397 & -18.0288 \\
& 0.06392 & 0.06275 & 0.00117 & -32.14914 \\
& 0.04752 & 0.05808 & -0.01055 & -10.66828 \\
& 0.01342 & 0.0133 & 0.00012 & -10.8877 \\
& 0.05744 & 0.06128 & -0.00384 & -14.41545 \\
& 0.05061 & 0.04787 & 0.00275 & -18.46369 \\
& 0.03003 & 0.0297 & 0.00034 & -9.47193 \\
& 0.01925 & 0.01528 & 0.00397 & -4.04217 \\
& 0.02574 & 0.02066 & 0.00509 & -13.91337 \\
& 0.01881 & 0.01391 & 0.0049 & -4.88274 \\
& 0.01638 & 0.02242 & -0.00604 & -16.3671 \\
& 0.02274 & 0.01938 & 0.00336 & -13.0568 \\
& 0.00362 & 0.00234 & 0.00129 & -2.62851 \\
& 0.00565 & 0.00035 & 0.00529 & -0.3412 \\
& 0.02008 & 0.0142 & 0.00588 & -6.65896 \\
& 0.00803 & 0.00643 & 0.00161 & -2.1982 \\
& 0.01196 & 0.01182 & 0.00013 & -8.94862 \\
& 0.00779 & 0.00818 & -0.00039 & -6.50818 \\
& 0.00198 & 0.00032 & 0.00166 & -0.47871 \\
& 0.00691 & 0.00445 & 0.00246 & -3.86776 \\
& 0.00063 & 0.00076 & -0.00013 & -2.35421 \\
& 0.00056 & 0.0019 & -0.00134 & -2.87749 \\
& 0.00207 & 0.00001 & 0.00206 & -0.01833 \\
& 0.00084 & 0.00076 & 0.00008 & -1.80369 \\
& 0.00024 & 0.00013 & 0.00011 & -1.24812 \\
\hline
\end{tabular}

$\chi^{2}$-value $=6606.74$

$95 \%$ Critical Value $=66.34$

$\mathrm{P}$-value $=0$

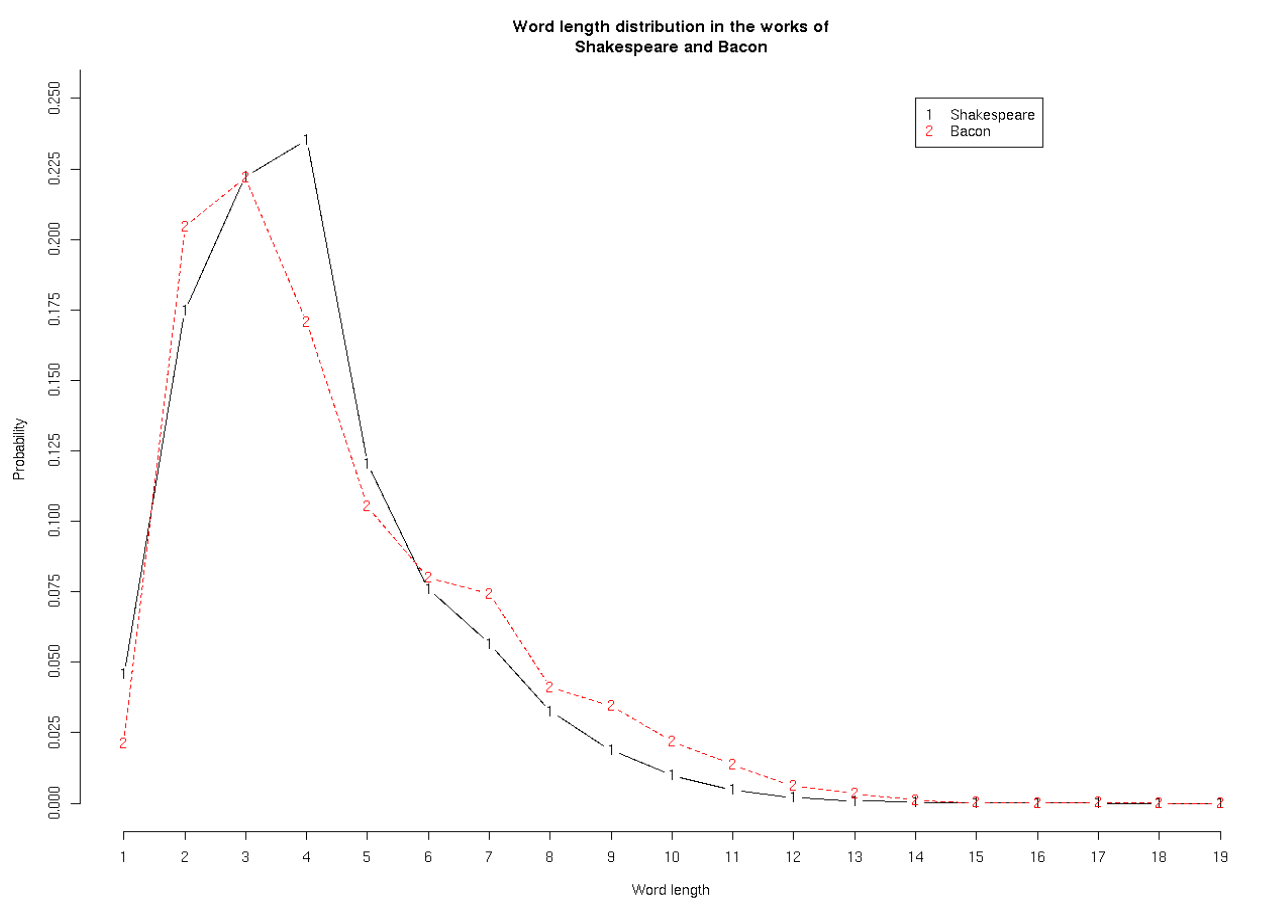

Fig-4: Average Word Length Probabilities: Shakespeare and Bacon 
Table-5: Word Length Probability Averages: Shakespeare and Bacon

\begin{tabular}{|l|l|l|l|l|}
\hline Length & Shakespeare & Marlowe & Difference & Z-score \\
\hline 1 & 0.0459 & 0.0213 & 0.0246 & 3.3783 \\
\hline 2 & 0.1747 & 0.2046 & -0.0299 & -2.7564 \\
\hline 3 & 0.2223 & 0.2219 & 0.0004 & 0.0284 \\
\hline 4 & 0.2352 & 0.1707 & 0.0646 & 2.5493 \\
\hline 5 & 0.1203 & 0.1052 & 0.0151 & 1.3481 \\
\hline 6 & 0.0759 & 0.08 & -0.0041 & -0.7713 \\
\hline 7 & 0.0565 & 0.0741 & -0.0176 & -0.9183 \\
\hline 8 & 0.0325 & 0.0411 & -0.0086 & -1.937 \\
\hline 9 & 0.0187 & 0.0345 & -0.0159 & -2.966 \\
\hline 10 & 0.01 & 0.0219 & -0.0119 & -2.2019 \\
\hline 11 & 0.0046 & 0.0137 & -0.009 & -2.6368 \\
\hline 12 & 0.0019 & 0.0061 & -0.0042 & -2.1959 \\
\hline 13 & 0.0008 & 0.0034 & -0.0026 & -1.9021 \\
\hline 14 & 0.0003 & 0.0011 & -0.0007 & -1.468 \\
\hline 15 & 0.0002 & 0.0002 & -0.0001 & -0.3665 \\
\hline \multicolumn{4}{|c|}{$\chi 2$-value $=65.85$} \\
\end{tabular}

$95 \%$ Critical Value $=28.89$

$\mathrm{P}$-value $=2.25 \mathrm{E}-07$

Character Distribution Comparson

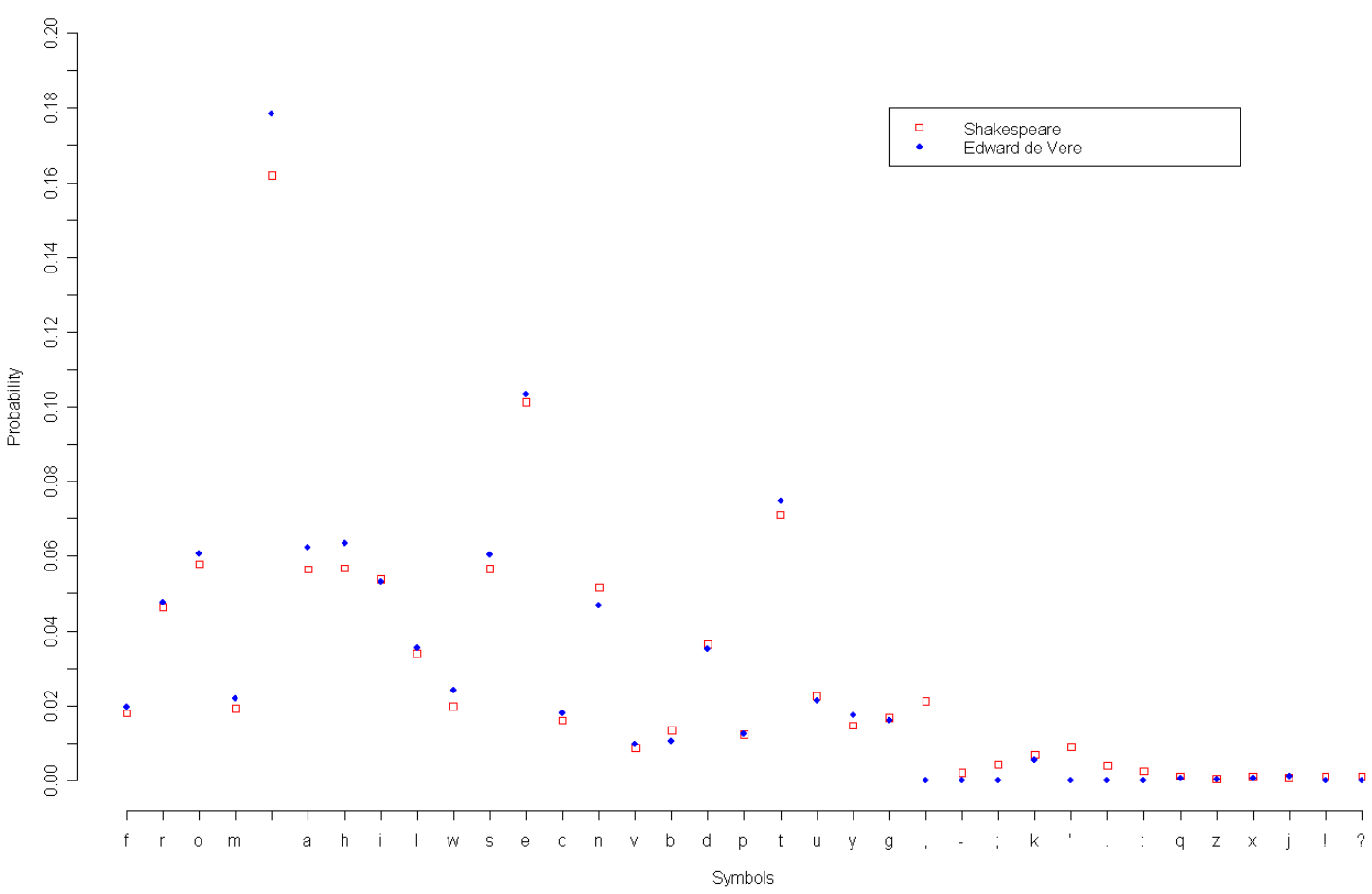

Fig-5: Character Probabilities: Shakespeare and Edward de Vere 


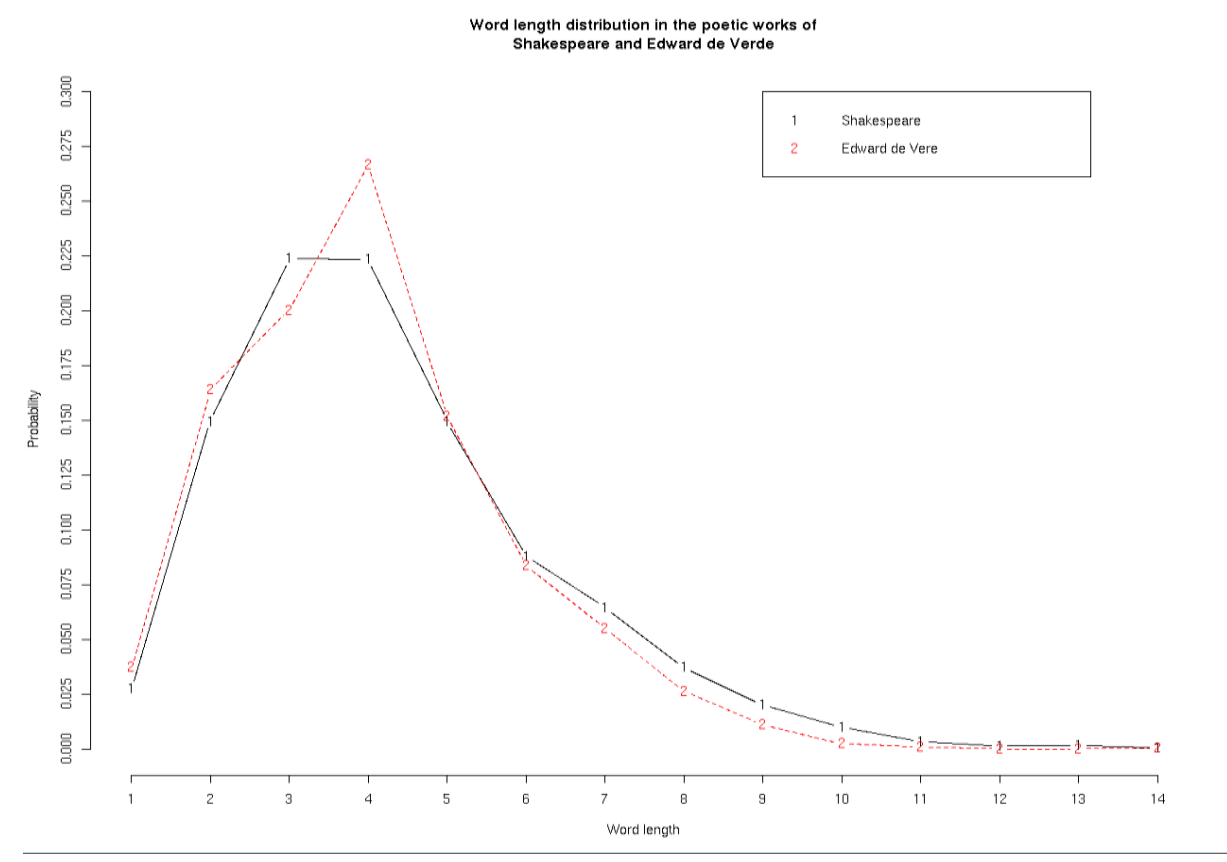

Fig-6: Average Word Length Probabilities: Shakespeare and Bacon

Table-6: Character Probability Averages: Shakespeare and Edward de Vere

\begin{tabular}{|c|c|c|c|c|}
\hline Symbol & Shakespeare & de Vere & Difference & Z-score \\
\hline $\mathrm{f}$ & 0.01797 & 0.01967 & -0.0017 & -1.40985 \\
\hline \multirow[t]{2}{*}{ rom } & 0.04644 & 0.04749 & -0.00105 & -0.56543 \\
\hline & 0.05789 & 0.06071 & -0.00282 & -1.35334 \\
\hline a hilwsec nvbdptuyg & 0.01926 & 0.02191 & -0.00265 & -2.0999 \\
\hline , & 0.16202 & 0.17853 & -0.01652 & -4.9629 \\
\hline- & 0.05647 & 0.06224 & -0.00577 & -2.75457 \\
\hline ; & 0.05674 & 0.06339 & -0.00665 & -3.15152 \\
\hline $\mathrm{k}$ & 0.05383 & 0.05323 & 0.00061 & 0.30668 \\
\hline . & 0.0339 & 0.03552 & -0.00162 & -1.00551 \\
\hline : & 0.01987 & 0.0241 & -0.00423 & -3.2219 \\
\hline$q z \times j$ & 0.05661 & 0.06033 & -0.00372 & -1.79557 \\
\hline ! & 0.10117 & 0.10328 & -0.00211 & -0.79264 \\
\hline ? & 0.01606 & 0.01792 & -0.00187 & -1.62616 \\
\hline & 0.05165 & 0.04683 & 0.00481 & 2.55611 \\
\hline & 0.00866 & 0.00967 & -0.00101 & -1.19566 \\
\hline & 0.01342 & 0.01038 & 0.00304 & 3.27326 \\
\hline & 0.03642 & 0.03514 & 0.00128 & 0.78945 \\
\hline & 0.01231 & 0.01246 & -0.00015 & -0.15009 \\
\hline & 0.071 & 0.07465 & -0.00365 & -1.59271 \\
\hline & 0.02255 & 0.02126 & 0.00129 & 1.01264 \\
\hline & 0.01464 & 0.01732 & -0.00269 & -2.39782 \\
\hline & 0.01676 & 0.01601 & 0.00074 & 0.67077 \\
\hline & 0.02122 & 0 & 0.02122 & 31.0065 \\
\hline & 0.00201 & 0 & 0.00201 & 9.44346 \\
\hline & 0.00431 & 0 & 0.00431 & 13.85014 \\
\hline & 0.00686 & 0.00563 & 0.00123 & 1.81059 \\
\hline & 0.00895 & 0 & 0.00895 & 20.01466 \\
\hline & 0.0039 & 0 & 0.0039 & 13.17868 \\
\hline & 0.00244 & 0 & 0.00244 & 10.40498 \\
\hline & 0.00104 & 0.00055 & 0.00049 & 2.12809 \\
\hline & 0.00041 & 0.00022 & 0.00019 & 1.28997 \\
\hline & 0.00088 & 0.00049 & 0.00039 & 1.79447 \\
\hline & 0.00068 & 0.00104 & -0.00036 & -1.34875 \\
\hline & 0.00086 & 0 & 0.00086 & 6.16706 \\
\hline & 0.00083 & 0 & 0.00083 & 6.0853 \\
\hline
\end{tabular}


Table-7: Word Length Probability Averages: Shakespeare and de Vere

\begin{tabular}{|c|c|c|c|c|}
\hline Length & Shakespeare & Marlowe & Difference & Z-score \\
\hline 1 & 0.0276 & 0.0372 & -0.0096 & -2.6887 \\
\hline 2 & 0.1495 & 0.1642 & -0.0147 & -2.0425 \\
\hline 3 & 0.2239 & 0.2004 & 0.0235 & 2.9478 \\
\hline 4 & 0.2235 & 0.2668 & -0.0433 & -5.0714 \\
\hline 5 & 0.1495 & 0.1519 & -0.0024 & -0.3409 \\
\hline 6 & 0.0878 & 0.0836 & 0.0042 & 0.7665 \\
\hline 7 & 0.0646 & 0.0552 & 0.0094 & 2.0438 \\
\hline 8 & 0.0372 & 0.0263 & 0.0109 & 3.2668 \\
\hline 9 & 0.02 & 0.011 & 0.009 & 3.9235 \\
\hline 10 & 0.0097 & 0.0024 & 0.0073 & 5.4404 \\
\hline 11 & 0.0034 & 0.0008 & 0.0026 & 3.2937 \\
\hline 12 & 0.0013 & 0 & 0.0013 & 3.2747 \\
\hline 13 & 0.0015 & 0 & 0.0015 & 3.5179 \\
\hline 14 & 0.0005 & 0.0003 & 0.0002 & 0.5343 \\
\hline \multicolumn{5}{|c}{$\chi 2$-value =18.87 } \\
\hline
\end{tabular}

Table-8: Probability of Unique Words in Poetry

\begin{tabular}{|c|c|c|}
\hline & Shakespeare & de Vere \\
\hline Variance & $2.53 \mathrm{E}-05$ & 0.31 \\
\hline Mean & $5.71 \mathrm{E}-05$ & 0.31 \\
\hline (Oleg Seletsky, Tiger Huang and William Henderson-Frost, "Shakespeare \\
Algorithm Study") & & \\
\end{tabular}

It is important to bear in mind that Shakspere from Stratford was born in 1564. Is it likely that a man with a grammar school education from the country could have been so accomplished in the refined English spoken at the Court in addition to being versed in several other languages, not least Latin, Greek, Italian, Spanish, and French? Let's be realistic. One would have to be tutored from a young age in these languages to acquire such accomplishments. And this precludes the expert knowledge the plays demonstrate of the law, medicine, history, world literature, and various branches of the sciences, including abstract sciences like metaphysics and astrology. All this without a university education? That would be absurd. Even Thomas Hardy as late as the 19th century expressed outrage at being barred from an Oxford education because of his commoner background through the character Jude in Jude the Obscure, in order to avoid the class and social repercussions of voicing his sentiments in an essay. How could a man of Will Shakspere's humble roots acquire all these gifts? The objection is usually met with charges of elitism. They are right, of course, it does imply elitist snobbery. That's because elitist class snobbery was and is a reality of British class society then and now. Having experienced it firsthand for five years, the author of this book can attest to the realities of class oppression in Britain in the 1980s and '90s, never mind the 16th century.

If Will Shakspere came to London in the mid1580 s - which seems plausible as he would have passed through the rite of passage known as adolescence by then and would have been a spry 20 - he could not have written Hamlet, for that play, according to contemporary Thomas Nash (another Bacon mask), was already on the stage in London; he could not have penned Two Gentleman of Verona, as that play was performed before the Queen in January of 1585; nor could he have authored Titus Andronicus or Pericles or The Troublesome Reign of King John, or The Famous Victories of Henry $V$, or King Leir and His Three Daughters, all of which were performed before Two Gentleman of Verona. It simply beggars belief that Will Shakspere could have authored these plays, since they were as replete in legal, scientific and classical knowledge as any of the later plays, and show the hand of at least one accomplished scholar at work [45].

Another dating problem with the plays involves Titus Andronicus. The earliest extant edition of the play is the anonymous quarto - a four-leafed pamphlet edition-that appeared in 1600. The anonymity factor is important to consider. Why would the authorship of the play be anonymous at this stage? If it were written by Will Shakspere, what did he have to hide? Or a better question would be why would he have to hide? It makes no sense. It is not political in the sense that many of the other plays are. There is no good reason for why the Stratford man would have to conceal his identity. There is no need for him to deny himself credit for authoring this play. However, it would make sense for some more illustrious author to do so, a member of the aristocracy, a court official for instance. 
It was taboo for a nobleman to write plays in all cultures, not just in England; the same practice was adhered to in the courts of Europe and even far-flung courts overseas like those of India, China, Choson (Korea), and Nippon (Japan).

The second quarto edition of Titus Andronicus, mostly unchanged from the first, is dated 1611. That would be just after the death of de Vere, who died in exile on the penal island situated just off the coast of Essex County, called the isle of Mersea. His official death was in 1604, but he staged his death at the behest of King James I, who had several Shakespeare plays performed for the occasion of his mock funeral. But the play would make a third appearance in the Shakespeare Folio of 1623, where an entire new scene was added, Act III, scene ii. This of course is long after the death of Will Shakspere and the Earl of Oxford. The conclusion of the Cambridge editors is that it agreed too closely in style with the original to be the brainchild of a new author. The only candidate for the authorship still alive by this point was Francis Bacon. While Oxford could very well be the author of many of the plays, his fellow Tudor prince and half-brother, Francis Bacon, is the candidate most likely to have penned Titus Andronicus, given that his 1623 editions match the style of the earlier quartos [46].

Then there is the comedy The Merry Wives of Windsor, where the first edition appeared in 1602. A second edition appeared in 1619, three years after Will Shakspere's death and long after Lord Oxford had left this world. What is even more telling is the fact that a new and greatly enlarged version appeared in the 1623 Shakespeare Folio, with the number of lines increased from 1,620 to 2,701, and so surpassing the 1602 and 1619 versions as to diminish them to that of an imperfect sketch or outline for a play [47].

The masterpiece Hamlet first appeared in 1603, the year Queen Elizabeth I died. Probably because it would have met with such strong disapproval from the Queen, given its strong political allusions, that the author(s) had to wait till the end of her reign to pursue its publication. However, it had been known on the stage for 17 years prior to that date, where Hamlet is mentioned in an address to the student body of Oxford and Cambridge: "Yet English Seneca, read by candlelight, yields many as 'blood is a beggar,' and so forth; and if you entreat him fair in a frosty morning, he will afford you whole Hamlets, I should say handfuls of tragical speeches [48]." The address is credited to Thomas Nash, whom Alfred Dodd, Elizabeth Gallop and other Baconians have claimed is really another Baconian mask. In other words, Bacon, employing the pseudonym, Thomas Nash, is heaping praise upon Oxford and himself, the Tudor prince authors. The second edition was issued in 1604, the official year of Lord Oxford's death, when he had actually faked his demise, and was exiled to the penal island of Mersea.
This was done in order to put King James I at ease that Oxford would not pose a threat to the throne. Why did King James I not exile the other Tudor prince, Francis Bacon? It is most likely due to Bacon's greater discretion, and the fact that the Queen had had all the records pertaining to her son's right of succession destroyed.

The second edition in 1604 presented a revision so radical and so vastly improved as to make this play stand on its own almost as a separate work. A third edition was issued in 1605, and a fourth in 1611 . These were followed by a fifth edition issued without date, but subsequent to 1611. The Shakespeare Folio version differs from the quartos in revealing ways, most notably in its exclusion of two theories, which up to that time had been included in the previous versions, one relating to the cause of the tides, repudiated by Bacon in his scientific prose writings in 1616, and the other related to the principle of motion, a scientific theory repudiated by Bacon in 1623 [49]. Hamlet seems uniquely autobiographical of Lord Oxford, so much so that even Sigmund Freud matched the psychological portrait of Prince Hamlet with that of Edward de Vere. That notwithstanding, it is conceivable that his halfbrother, Francis Bacon either edited and expanded his brother's work or wrote it himself based on biographical details from his half-brother's life, making improvements and alterations to the masterpiece as late as 1623 . Bacon does in fact take credit for authoring the plays in an embedded cipher biography discovered by Elizabeth Gallup. This particular embedded cipher message was contained within a play originally turned out as Sir John Old-Castle and The Merchant of Venice:

\section{BLOCK QUOTE BEGINS}

In the stage-plaies, two, the oldest or earliest devices prove these twentie plays to have bin put upon the stage by the actor that is suppose'd to sell dramas of value, yet is rightly my owne labor [50].

\section{BLOCK QUOTE ENDS}

Below is an excerpt of the only surviving play script to contain Shakespeare's actual handwriting. At issue are three surviving pages of the manuscript, ff. $8 \mathrm{r}$, $8 \mathrm{v}$, and 9r, which have been identified as the work of Shakespeare, based on handwriting, spelling, vocabulary and the images and ideas expressed. What is interesting to note is the fact that there is no way of matching this Shakespearean insertion in the play to any other handwritten document of Shakespeare's. However, as an insertion it certainly displays all the hallmark characteristics of his style. However, what is clearly discernible is the fact that the handwriting displayed in these three pages perfectly matches the handwriting of Francis Bacon, who functioned as editor and reviser of the works of 'Shakespeare' and others writing for his secret writing ministry known as Fra Rosi Cross or the Honourable Order of the Knights of the Helmet. 
The play is a biographical work about the life of Sir Thomas More, the Tudor lawyer sentenced to death for refusing to accept Henry VIII's claim to being the Supreme Head of the Church of England. The work was initially penned by Anthony Munday (another Bacon mask) between 1596 and 1601, which seems to prove Bacon's authorship of the whole. Edmund Tilney, the Master of the Revels, as the stage censor of the period, banned the play Sir Thomas More ostensibly because he worried that the play's graphic depiction of riots might inspire an actual civil insurrection at a very unstable time in English history.

After Queen Elizabeth's death in 1603, 'Shakespeare' was tasked with revising the script, with the assistance of three other playwrights. Shakespeare's additions include 147 lines in the middle of a riotous event, in which More is called upon to address an antiimmigration riot taking place on the street. He delivers an impassioned speech making a plea for peace to an aggressive mob calling for the banishment of those they regard as 'strangers':

\section{BLOCK QUOTE BEGINS}

You'll put down strangers,

Kill them, cut their throats, possess their houses,

And lead the majesty of law in lyam

To slip him like a hound; alas, alas, say now the King,

As he is clement if th'offender mourn,

Should so much come too short of your great trespass

As but to banish you: whither would you go?

What country, by the nature of your error,

Should give you harbour? Go you to France or Flanders,

To any German province, Spain or Portugal, Nay, anywhere that not adheres to England,
Why, you must needs be strangers, would you be pleas'd

To find a nation of such barbarous temper

That breaking out in hideous violence

Would not afford you an abode on earth.

Whet their detested knives against your throats,

Spurn you like dogs, and like as if that God

Owed not nor made not you, not that the elements

Were not all appropriate to your comforts,

But charter'd unto them? What would you think

To be us'd thus? This is the strangers' case

And this your mountainish inhumanity [51].

\section{BLOCK QUOTE ENDS}

The character of Sir Thomas More makes an appeal to empathy in the speech by making the rioters see that, if they were suddenly banished to a foreign land, they would find themselves in the same boat as the poor wretches for whom they show a shameful intolerance. The speech by More is clearly intended for a larger audience than the rioters depicted in the play. It is the author's call to action to his fellow countrymen of the day to show more compassion to displaced refugees. The message carries striking relevance to events of our time with the refugee crisis facing the West in the Trump years. Proving that More's words were written by Shakespeare is no easy matter, though they do seem to anticipate the same appeal to reason against rash racial emotion as found in The Merchant of Venice and Othello. Along with Shakespeare, there are additions to the manuscript made by Henry Chettle, Thomas Dekker, Thomas Heywood, and an anonymous copyist. There is no evidence that the play was ever performed or published [52].

The following two manuscript pages from The Book of Sir Thomas More offer the clearest samples of Shakespeare the Bard's actual handwriting. 

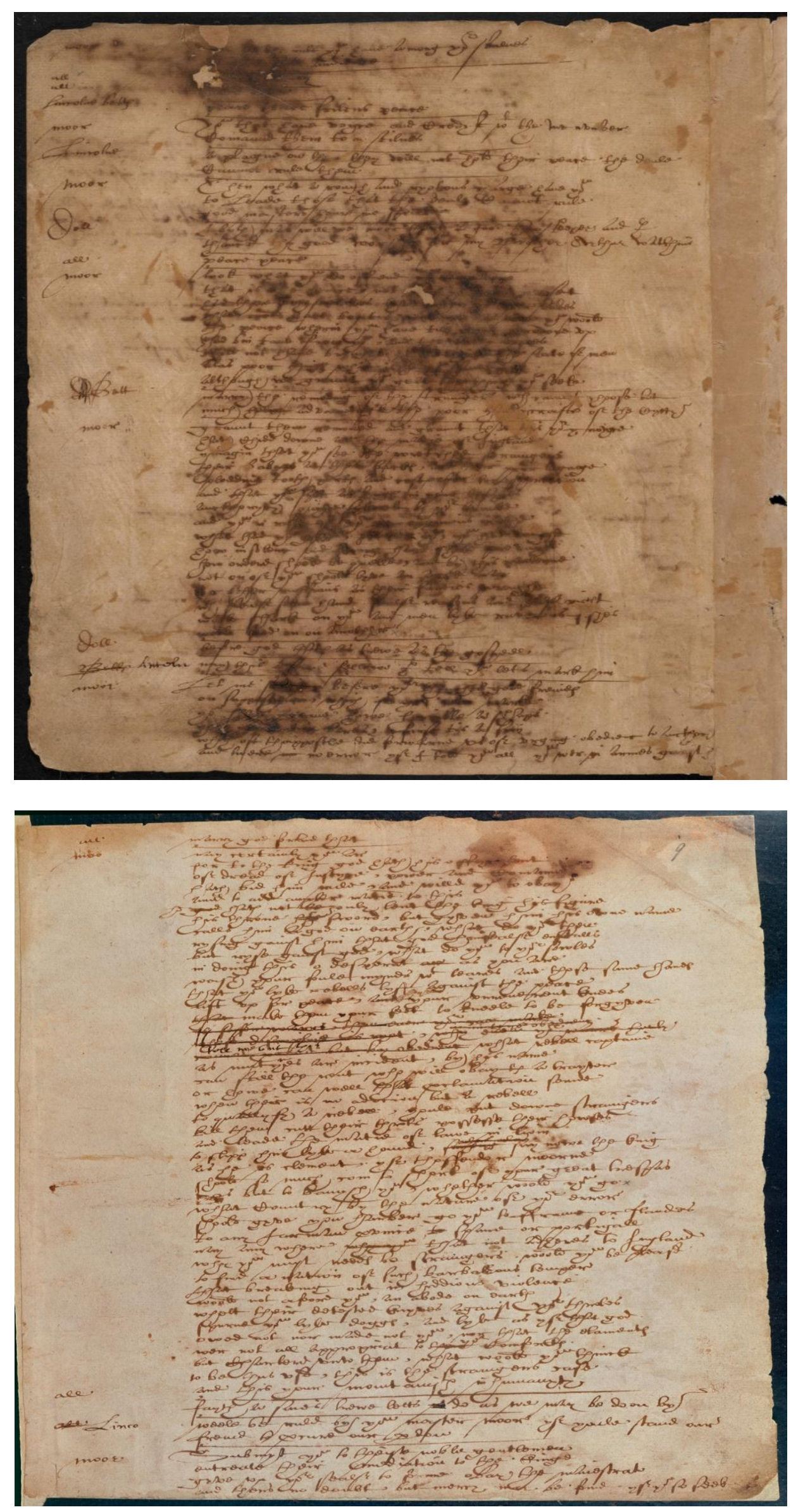
Of the three extant pages in question, the handwriting just happens to be a perfect match for that of Sir Francis Bacon. Perhaps the reason these facts surrounding this manuscript are so little known is that it poses an alarming threat to Stratfordians-those who attribute the plays to Will Shakspere of Stratford. The reader is simply asked to compare the handwriting featured in the three pages of the Sir Thomas More manuscript with that of Francis Bacon displayed below so that they can reach a conclusion on their own [53].

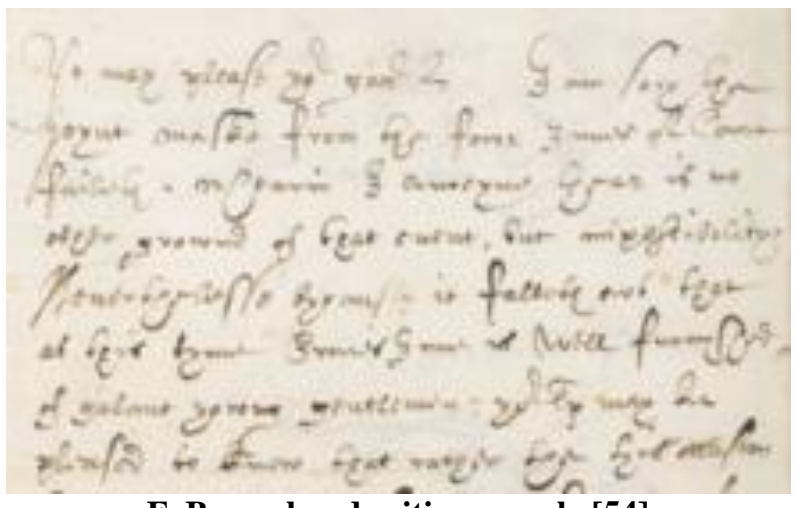

\section{F. Bacon handwriting sample [54]}

As for the play Henry VI, it first appeared anonymously in quarto form in 1594 under the title, The First Part of the Contention Betwixt the Two Famous Houses of York and Lancaster. It contained 2,214 lines at that time. Six years later in 1600, a second edition appeared also anonymously. In 1619, it made another reappearance with an announcement on the title page that it had been "newly corrected and enlarged." There were many important changes, and this three years after the reputed author, the Stratford man, had left this world. A fourth version appeared in the 1623 Folio under a brand-new title and with an additional 1,139 lines. As for the original 2,214 lines from the older 1619 version of the play, nearly 2,000 lines were retouched. This revision work was undertaken between the years 1619 to 1623 , which means that it was begun three years after the Stratford man had died in 1616.

In considering the play Othello, it was never printed in any form during the lifetime of Will Shakspere, the reputed author of orthodoxy. It was first printed in 1622, six years after Shakspere's death. In addition, the Shakespeare Folio version, issued just one year later in 1623, included an additional 160 words and numerous changes here and there throughout the text [55].

Richard III was first published anonymously in 1597. In 1598, a second edition appeared, this time attributed to William Shake-speare. This was followed by a third edition in 1602 , a fourth in 1605 , a fifth in 1612 , and a sixth in 1622. When the final version appeared in the Shakespeare Folio of 1623, there were many improvements made to the text. The changes made to the text in the final Folio version of 1623 included 193 new lines and as many as 2,000 retouched lines from the previous 1622 edition [56].

In his last will and testament, Francis Bacon, who died April 9, 1626, made provision that his unpublished writings be published posthumously, requesting, "I desire my executors . . . presently after my decease, to take into their hands all my papers whatsoever, which are either in cabinets, boxes, or presses, and them to seal up till they may at their leisure peruse them [57]." Sometime after Bacon's death, most likely in 1627, Sir William Boswell, resident ambassador to the Netherlands, carried the philosopher's manuscripts with him to Holland, where he presented them to Isaac Gruter for publication. Among these manuscripts was The History of Henry $V I I$, well known as one of the Shakespeare history plays [58].

Amazingly, there is a man named Ignatius L. Donnelly, a U.S. congressman who once made a run at the presidency, who proved himself to be a first-rate scholar as well. He wrote a seminal work on the subject of the Shakespeare authorship titled, Great Cryptogram: Francis Bacon's Cipher in the So-called Shakespeare Plays. The cipher code was based on a cabalistic letter sequence and word number count system that left a concealed message in several Shakespeare plays related to the entire covert operation to conceal the authorship. The level of artistry and scientific design involved is hard to fathom and proves that the authors of the day were playing threedimensional chess while the rest of us continue to exercise our paltry skills on a two-dimensional chessboard. Without going into the particulars of the amazingly advanced cipher system at this stage, suffice to say that there is an embedded and coded message in the so-called Henry plays, which is only fitting because Lord Oxford is disguised in those plays as Prince Hal and later as King Henry IV. In one cipher code beginning at word 53 on page and column 75:1 combining with word 182 on page and column 76:1, a covert message is left to posterity attributing the authorship to none other than Edward de Vere, the Earl of Oxford. The Queen and her close and trusted advisor, William Cecil-identified in the cipher message by the words (Seas ill) - interrogated the publisher Hayward later identified by the words (Ha word) as to why he published the identity of the true author on the dedication page of The History of Henry IV:

\section{BLOCK QUOTE BEGINS}

Seas ill said to him: Come, speak out. Why didst thou put the name of my Lord the Earl upon the title-leaf of this volume? [59].

\section{BLOCK QUOTE ENDS}

That's pretty striking confirmation that the author of one of the most famous Shakespearean history plays is an earl. Granted, it does leave the open-ended 
question, which earl, since other earls have been advanced historically as possible authors of the Shakespeare plays, but this does rather rule out Bacon as a candidate, since he was the Viscount of St Albans and no earl.

The embedded cipher message goes on with perfect grammar and syntax to offer an account of the interrogation of the publisher Hayward-identified by the words "Ha word" in the passage - for committing some offense to offend the Queen and summon forth her wrath:

\section{BLOCK QUOTE BEGINS}

The sullen old jade doth listen with the ugliest frown upon her hateful brows too enlarged to, speak; but, rising up and starting forwards, took ( $\mathrm{Ha}$ word) by his throat and choked him. He took to his heels and was running off in the greatest fright, but the old jade struck my poor young friend a fearful blow with the steeled end of the great crutch, again and again. His limbs being now so weakened by imprisonment and grief, he is not able to stand the force of the blows; the hinges of his joints gave way under him; and he fell bleeding on the stones [60].

\section{BLOCK QUOTE ENDS}

The encoded messages Donnelly has unearthed in the Henry plays could not be more significant because it is in those plays that we are given the most authentic autobiographical portrait of the Earl of Oxford. It is no surprise then that the embedded cipher code contained therein alludes to this in the following occulted message: "It is plain that my Lord the Earl is young Harry Monmouth, Prince of Wales, the Duke of Monmouth's son."

In fact, not only do the Henry plays furnish us with a portrait of Oxford in the personage of Harry Percy, but also that of his cousin through the Arden family and youthful companion, Will Shakspere, who appears in the play in the personage of Sir John Falstaff (False-staff or False-spear). It is within the encrypted cipher message that we learn the truth about the covert operation that is the "wild goose chase" of the Wild Goose Club. And it is in this play that the encrypted message reveals the identities of the two front men who would stand in for the authorship, they being first, Christopher Marlowe, and later the man from Stratford who was the son of a glove-maker:

\section{BLOCK QUOTE BEGINS}

Many rumors are on the tongues of men that my cousin hath prepared not only the contention between York and Lancaster and King John and this play, but other plays which are put forth under the name of More low (Marlowe) and now go abroad as prepared by Shak'st spurre (Stratford man Will Shakspere) [61].

\section{BLOCK QUOTE ENDS}

It should come as no surprise that the man to receive payment for the staging of the plays at The Fortune and The Curtain and other theaters mentioned in the cipher code is the Stratford man, Will Shakspere. In a series of embedded cipher codes, the personage of William Cecil, better known to posterity as Lord Burghley, gives away the wild goose chase by killing and marinating the bird for future generations' consumption: "Seas ill (Cecil) said that More low (Marlowe) or Shak'st spur never writ a word of them [62]." This embedded cipher message disqualifies Shakspere, the man from Stratford, and Christopher Marlowe as candidates for the Shakespeare authorship, but we also have a portrait of Shakspere drawn for us by the personage of Cecil, as a mere frontman or mask for someone else:

\section{BLOCK QUOTE BEGINS}

$\mathrm{He}$ is a poor, dull, ill-spirited, greedy creature and but a veil for someone else, who had blown up the flame of rebellion almost into war against your Grace as a royal tyrant [63].

\section{BLOCK QUOTE ENDS}

Not only does the encoded cipher message reveal the identities of the two front men who took the credit for the Shakespeare plays and fronted as the Bard, but we are provided with the identity of the actual author as well in the following embedded message, in which Lord Burghley reveals that the man to receive payment for the staging of the plays at The Fortune and The Curtain theatrical venues is none other than him whom the character of Harry Percy represents on the stage:

\section{BLOCK QUOTE BEGINS}

I have a suspicion that my kinsman's servant, young Harry Percy, was the man to whom he gave every night the half of what he took through the day at the gate [64].

\section{BLOCK QUOTE ENDS}

What is implied from this imbedded cipher message is that Will Shakspere is being paid a handsome sum for his services playing the role of the frontman for the Bard.

Ignatius Donnelly deserves full credit for doing such an excellent job of breaking the cipher code in the plays. But he is not alone. Other Shakespeare scholars have been extremely helpful in this endeavor. Edwin Durning-Lawrence has made another great contribution to the mathematical and numerological ciphers inserted in the plays. In his case, the heart of the discussion focuses on the play Love's Labour's Lost. The long word Honorificabilitudinitatibus is found in Love's Labour's Lost near the beginning of Act V, called Actus Quartus in the 1623 Folio. The word Honorificabilitudinitatibus appeared on the 27th line of 
page 136 of the Folio edition. On lines 14-15 of page 136, there appears the phrase, "Bome boon for boon prescian, a little scratch "twill serve [65]." This line alludes to a pedantic grammarian named Priscian, though the name is spelled "prescian" in Love's Labour's Lost. Why refer to him at all? Since his name has no significance to anything in the text nor has it anything to do with the dramatic action. It rather refers solely and entirely to the phrase which is to be formed from the transposition of the 27 letters contained in the long word Honorificabilitudinitatibus. The revealed sentence forms a correct Latin hexameter. It is intended to prove without doubt that the Shakespeare plays are the property of their author, who conceived the entire schema of the plays, and with the probable assistance of his half-brother and fellow poet-Edward TudorSeymour aka Edward de Vere, the Earl of Oxford-has put his claim to the plays for all posterity. First of all, there is little doubt that this particular play, Love's Labour's Lost, is Francis Bacon's work. Therefore, when Bacon inserted the long word, Honorificabilitudinitatibus, which is composed of 27 letters, he placed it on the 27th line of page 136 of the 1623 Folio, where it appears as the 151 st word printed in ordinary type. The Latin hexameter reads as follows:

\section{BLOCK QUOTE BEGINS (align words as below)}

HI LUDI F. BACON NATI TUITI ORBI

These plays F. Bacon's offspring are preserved for the world [66].

\section{BLOCK QUOTE ENDS}

Bacon deliberately arranged the plays and the acts of the plays in the 1623 Shakespeare Folio with an expressed purpose. The purpose he executed was to have the long word, Honorificabilitudinitatibus, on page 136 as the 151 st word, falling on line 27 , so that the interpretation should indicate the numbers 136 and 151 , the aim being to create a mathematical proof that the word and the message was placed there by design, so its meaning could not be discounted or explained away by appeal to "odd coincidences."

The Latin hexagram and its meaning must have been constructed before Love's Labour's Lost first appeared in 1598. Thus, when the plays were printed for the 1623 Folio, the scenes and acts of the preceding plays and the printing of the columns had to be arranged with extraordinary skill in order to ensure that the revealing page in question should commence with the first word of the revealing page in the original quarto of 1598 , so that this page should form the 136th page of the Shakespeare Folio of 1623, in order that the long word Honorificabilitudinitatibus should appear on page 136 as the 151 st word on the 27 th line [67].

There is a numerological significance to all this as well. For instance, Bacon's own name is derived of $\mathrm{B}=2, \mathrm{~A}=1, \mathrm{C}=3, \mathrm{O}=14, \mathrm{~N}=13$. When we add all these numbers together, we arrive at the figure 33 .
When we apply the numerical value of the letters forming the long word, the total comes to 287 :

\section{BLOCK QUOTE BEGINS (align letter and numbers) \\ H O N O R I F I C A B I L I T U D I N I T A T I B U S \\ 814131417969312911919204913919119 \\ $922018=287$}

\section{BLOCK QUOTE ENDS}

On page 136 of the 1623 Folio, numbers are placed pointing to the fact that the long word Honorificabilitudinitatibus is on the 27th line, which was deliberately placed of course, because there are 27 letters in the word itself. There is another set of numbers at the other side of the page, which reveals that - counting from the first word-the long word is the 151st word. How is it possible that the revealing sentence, "Hi ludi F. Bacon nati tuiti orbi," tells us that the page is 136 and the long word is the 151st word appearing on that page? This can be explained quite simply. The numerical value of the initial letters and of the terminal letters of the revealed sentence arrive at the sum of 136 when added together, which is the actual page number. At the same time, the numerical value of all the other letters arrive at the sum 151, which is the position of the long word on that very page, where it appears as the 151st word on page 136 .

The solution is given below:

\section{BEGIN: CREATE AN IMAGE FOR THIS AND KEEP THE COLOR SCHEME \\ $\mathrm{HI}$ \\ LUDI \\ $\mathrm{F}$ \\ BACONIS \\ NATI \\ TUITI}

ORBI

The initial letters of which are as follows: $\mathrm{H}$

$\mathrm{L}$

$\mathrm{F}$

B

$\mathrm{N}$

$\mathrm{T}$

$\mathrm{O}$

The numerical value of these initial letters forming the anagram is:

H L F B N T O

$81162131914=73$

The terminal letters are as follows: I

I

S

I

I

I

The numerical value of these terminal letters is: I I S I I I 
$9918999=63$

When we add the two sums 73 to $63=136$

The intermediate letters are as follows:

UD

ACONI

AT

UIT

RB

Let's place them in order for order's sake:

U D A C O N I A T U I T R B

$204131413911920919172=151$ [68].

\section{LEGEND}

In Red $=$ initial letters

In Blue = terminal letters

In Green $=$ intermediate letters

\section{END: CREATE AN IMAGE FOR THIS}

Thus, in the revealed sentence, the sum of the numerical values of the initial letters, when added to the sum of the numerical value of the terminal letters, arrives at the sum total of 136 , the page number on which the revealed sentence "Hi ludi F. Bacon nati tuiti orbi" appears. Meanwhile, the sum of the intermediate letters in the revealed sentence amounts to 151, which gives the word count position of the long word Honorificabilitudinitatibus on page 136, which is 151st word. These two sums 136 and 151, when added together, arrive at the sum total of 287 , which is the sum of the numerical value of the letters forming the long word, Honorificabilitudinitatibus, which comes to a total numerological value of 287 [69].

In addition, there is a joke on page 136 of the Shakespeare Folio that reveals the truth in a more definitive form, on line 33, which has the numerical value of Bacon's name, the words: "What is Ab speld backward with the horn on his head?"

\section{BLOCK QUOTE BEGINS (align letter and numbers) \\ B A C O N}

$2131413=33$

\section{BLOCK QUOTE ENDS}

The answer which is given to this question is evidently incorrect. The answer is, "Ba, puericia with a horne added," and the character, the Boy, mocks him with the statement, "Ba, most seely sheepe, with a horne: you heare his learning." The reply should be in Latin obviously. The Latin for "horn" is cornu. The real answer is "Ba corn-u fool [70]." The answer will be even more clear to the Millennials who text message with U for "you," if U know what I mean.

The covert operation is hatched in A Comedy of Errors, the Bard's first staged production, which was performed in the dining hall of Gray's Inn, the law school attended by both Lord Oxford and Lord Bacon, which commoner Will Shakspere had nothing whatsoever to do with and would have been considered too base born to let through the front door, since it was an institution of higher learning reserved for the ranks of the upper class and nobility only. It is in A Comedy of Errors that the illustrious Freemason and Rosicrucian spawned HMSS hatched its covert operation known as the Shakespeare plays, for it is in this very play that we are introduced to two characters who look so much alike that they are mistaken for one another, initiating a comedy of errors. Well, Mesdames et Messieurs, it has been a 400-year comedy of errors and veritable wild goose chase, conceived in the view of this author, by the Great Author in Heaven to humble the arrogant and disdainful academics who think they know what they don't know.

Indeed, there were a multitude of motivations for concealing the true authorship of these literary masterpieces, some spiritual, others political. On the spiritual side, there is the intention of the time capsule of truth being opened at some future point when humanity has evolved to the level where the true value of the plays can be fully digested and appreciated, that time being now, one of the many reasons why this chapter and its contents are now being shared. The political motivation relates to the powerful propaganda vehicle that the plays represent and the targets at home and abroad that they intend to assail and attack in hopes of defending England "against all enemies foreign and domestic." And many of the plays fulfilled their intended political purpose. Many Britons were inflamed by the plays and provoked by the perception of foreigners and foreign powers that they conjured. In addition, foreign monarchs and courts abroad were often offended by the trouncing they were receiving at the hands of the Elizabethan theater. Othello would have been one of the plays that caused King Philip II such strong offense. "Moor" was a racial slur for Spaniard at this time, and King Philip of Spain would have seen himself reflected in the Moor, Othello, since he was rumored to have arranged the murders of his third wife, Elizabeth of Valois and the Princess of Eboli, the latter claimed to have been his mistress. With the production of Marlowe's Tamburlaine, probably launched a year later in 1587, King Philip probably would have been further offended. Envisioning himself as the master of land and sea, Tamburlaine boasts:

\section{BLOCK QUOTE BEGINS}

Even from Persepolis to Mexico,

And thence unto the Straits of Jubalter,

Where they shall meet and join their force in one,

Keeping in awe the Bay of Portingale

And all the ocean by the British shore.

And by this means I'll win the world at last.

(Marlowe's Tamburlaine, III, III, 11.207-212)

\section{BLOCK QUOTE ENDS}

Small wonder that the Spanish King would be so put out by the way he was represented on the 
Elizabethan stage. Why it should come as any surprise to anyone that the plays should be used for state propaganda purposes is simply astounding. We have to remember that a feudal system existed at this time in which each lord served an overlord. No man was free. To exhibit the kind of genius shown by the Tudor princes, Bacon and de Vere, would have been more of a curse than a blessing. Their talents would have been most certainly seized upon and used on behalf of the Queen, the Court and the state. Why should it be any surprise that Jonson, Marlowe, and the man posterity knows as Shakespeare be writing state propaganda on behalf of the Crown? Is not the same the case today with Hollywood writers turning out state propaganda on behalf of the U.S. government? Just as the English nobility are depicted as the bastion of heroism in the Shakespeare plays, so is the American hero a star shining with unrivalled brilliance in the firmament, witness Air Force One or Impact, both of which feature hero presidents. Examine any of the films starring Clint Eastwood, Sylvester Stallone, Harrison Ford, and innumerable others in which the American maverick is the model hero. Just as the author of the Shakespeare plays shows the English aristocracy as a caste that will set the nation to rights even when "the times are out of joint," so now is the American elite seen as the bastion of righteousness which will set to rights even the most corrupt and untoward of governments: Mr. Smith Goes to Washington, JFK, All the President's Men, and Lincoln to name but a few.

How would Lord Oxford have been selected for such an assignment? We have established that he worked for the British secret service. But can we establish under whose command he was assigned? We do know that Sir Francis Bacon and his brother Anthony were the founders of the British secret service. We know that both Francis Bacon and Edward de Vere studied law at Gray's Inn, one of the Inns of Court. We also know that A Comedy of Errors was performed for the first time in the Hall of Gray's, the dining hall in 1594 [71]. What is certain beyond doubt is that Will Shakspere of Stratford-upon-Avon did not and could not have studied at Gray's Inn even if he wanted to because he was not an aristocrat. It is even claimed that Bacon delighted in the theater and even staged plays himself at Gray's Inn. It is well known that Freemason and Baconian scholars have long promoted Bacon as the author of the Shakespeare plays.

On the other hand, a great deal of similarity has been found between Oxford's early verse, penned under his own name, and Shakespeare's. The Bénézet test devised by Professor Louis P. Bénézet is a good example of how many of the stylistic devices and language icons used by de Vere are identical to those of Shakespeare. The Bénézet test, which juxtaposes de Vere's early lines of verse with Shakespeare's, has defied the efforts of numerous scholars to identify which lines are Oxford's and which Shakespeare's [72].
It should be noted that other clandestine operations were going on at this time. Why is a propaganda ministry run by the secret service outside the realm of possibility? Not only was the English language canonized at this time, but the greatest literary works in the language were also being undertaken. Not only that, but the knowledge and wisdom of the classical writers, the histories of great nations, and practically everything else worth knowing from foreign countries was imported into the English language at this time. Books were printed and published on every art and science imaginable. In addition, the names on the title pages of these works are totally unknown. It is bewildering that so many men could be put to work on one arcane subject for the task of translating one book and one book only and to then disappear into the same obscure cloud from which they sprang [73]. This suggests that they were under hire of the intelligence service just as readers and researchers are called in by the CIA today. It suggests a large clandestine operation designed to plunder the coveted secrets of the Continent as part of an orchestrated effort to import the Renaissance from the Continent to England. Revealingly, many of the books published during the period 1576 to 1598 are dedicated to the Queen, the Earl of Leicester, and Lord Burghley. Leicester was the Queen's lover and clandestine husband, while Lord Burghley was the Queen's Chancellor. Together they constituted the most powerful triumvirate in the country. Bacon's intelligence service would naturally depend on funding from these personages in return for which the commissioned volumes would be dedicated to the benefactors. What is even more revealing from the intelligence service end of things is that Bacon oversaw the writing of many books during this period. He even supervised the printing process using his own wooden blocks, many of his own design, and each book under his direction was marked with such blocks, suggesting that he himself was acting as the state censor, ensuring on behalf of the Crown that every book published was politically correct [74].

What is certain is that both Tudor princes de Vere and Bacon had the intelligence-gathering skills required for the enterprise. Both had visited the foreign courts, where they had been dispatched in a diplomatic capacity. What is said of Bertram in All's Well That Ends Well, where he is told, "You have sold your own lands to see other lands," could equally be said of the earl, who did appeal to Lord Burghley in a letter to do the very same by agreeing to pay for his expenses abroad. Oxford traveled widely on the Continent [75]. $\mathrm{He}$ is known to have visited France and Italy with certainty. The fact that he was granted official permission to travel in 1575 implies that he was both eminent and trusted, since it was difficult at this time for anyone to get permission to travel. The fact that his visit to the Continent was given the official seal of approval and that he was permitted to travel widely to Paris, Strasburg, Padua, Venice, Florence, and Sicily 
suggests that he was on official business probably on behalf of the Crown and that it constituted a diplomatic mission. The fact that he was recalled in 1576 pushes the case for a diplomat on official business, since his itinerary was being monitored and his person was valued enough to be dispatched and recalled [76]. He was even known as the Italianate Englishman due to his tendency to wear the fashion of Renaissance Italy in the Court. He was also strongly influenced by Ovid, particularly Ovid's Metamorphosis, and was even referred to as the English Ovid.

Oxford did travel in Italy extensively. He traveled with a retinue, according to Lord Burghley of eight people, including two gentlemen, two grooms, one payend (a disperser of funds), a harbinger (someone who goes ahead to make arrangements), a housekeeper, and a trencherman (a cook). The author of the Shakespeare plays was clearly well acquainted with Italy and its cities. Professor Ernesto Grillo notes that Italy herself is mentioned some 800 times in the plays, while her cities are mentioned severally: Rome 400 times, Venice 52, Naples 34, Milan 25, Florence 23, Padua 22, and Verona 20. Genoa, Mantua, Pisa, Ferrera and other cities are also mentioned frequently [77]. In addition, it is evident that the avant-garde Italianate theatrical form, commedia dell'arte is particularly in evidence in plays like Love's Labour's Lost. It was a form of comedy in which the plot was written out, but the dialogue improvised on the stage. George Lyman Kittredge holds the opinion that Shakespeare's precise descriptions of scenes, laws, and customs spring from firsthand experience.

In addition, there is the massive influence Italian and Roman authors exerted on the Bard. Measure for Measure is influenced by the sixteenth century writer Giovambattista Cinzio; The Merchant of Venice is inspired by Il Pecorone of Florentino (1588); A Midsummer Night's Dream must credit Ovid's Metamorphosis as its muse. (Oxford worked on the translation of Ovid's Metamorphosis personally with his uncle Arthur Golding when still a boy); Much Ado About Nothing owes a debt to Matteo Bandello, a 15th century writer of novellas or tales; The Taming of the Shrew is based on Arioto's I Suppositi. And the basic plot of All's Well That Ends Well is drawn from the ninth novella of the third day of Boccaccio's Decameron [78].

Then there is the fact that Shakespeare has borrowed so many loan words from Latin. Alfred Hart credits Shakespeare with employing a vocabulary of 17,677 words, twice that of Milton and two and a half times that of Marlowe. So dexterous was he with words that he was able to employ 7,200 words, more than occur in the King James Version of the Bible. Lewis Theobold credits Shakespeare with the massive suffusion of Latin words into English. So immense was the rhetoric of the Italian Renaissance that it amazes even modern researchers, and so great a master was Shakespeare of this rhetoric that he introduced the vocabulary and syntax of the Italian Renaissance to England. Even the sonnets are modeled on the Petrarchan form. In fact, Shakespeare can be credited with single-handedly bringing the Italian Renaissance to England [79].

How could the Stratford man have gained so much firsthand knowledge about the Continent, particularly Italy? It was difficult even for nobles to travel at this time. A nobleman required special permission from the Queen to travel at a juncture in English history when Protestant England was under siege from the Continent. The Throckmorton Plot to unseat Queen Elizabeth I and the Northern Uprising prove that England was under great peril and in constant danger of plots hatched by France and Spain. Under siege as she was, Elizabethan England had a moratorium on travel as strict as that of former Soviet Bloc countries or North Korea today. It is unlikely Will Shakspere would have ever been granted such permission to travel, and there is certainly no evidence from any of the documented record that he ever was.

It seems likely then that the author(s) of the Shakespeare plays were dispatched to the Continent on intelligence-gathering missions to the foreign courts and returned to England to dramatize what had been learned abroad. As part of the propaganda network operating under Sir Francis Bacon, founder and head of British intelligence, Oxford would have acted as a patron to the other writers employed by the propaganda ministry Fra Rosi Cross, turning out plays with his apprentices that would have inspired great theatrical revels. No Elizabethan scholar has ever pointed out the formulaic nature of the Elizabethan theater with its tendency toward histories, comedies and tragedies among the various dramatists. It is as if they were all part of the same dramatic school. Even the titles of the plays among the various Elizabethan authors resemble each other, the Jonson play titled, Every Man Out of His Humor, resembling vintage Shakespeare.

As state propaganda, the history plays seem conceived to bring into relief the heroic exploits of the English nobility, in order to cultivate a feeling of national identity and pride in the patriotic playhouse. The comedies, on the other hand, were designed to lampoon and satirize the foreign courts, particularly that of France, and to paint them in a disparaging light, highlighting their decadence and dissolute ways. Tragedies like the Bard's Othello and Titus Andronicus, as well as Marlowe's Tamburlaine, as already revealed, are designed to make foreign monarchs like Philip II of Spain look like homicidal maniacs. Then, there are the tragedies closer to home like Hamlet, which seem not to have the foreign court as its target, but the Elizabethan Court instead. This accounts for why a pen name was required. Had Philip and other foreign monarchs been 
able to identify Oxford with the authorship of the very plays that so maligned them, the playwright would be vulnerable to political assassination. Closer to home, the identification of the author as a man of the Court would have exposed to public ridicule the high-ranking officials around him that are the targets of his plays, rendering him too vulnerable to political dangers including assassination. But even more serious is the issue of the plays and the sonnets, if read as Oxford's, exposing the true nature of his relationship with the Queen, a problem which the establishment sought to remedy through damage control. Suppression of the author's true identity was the means.

Another motive for a British intelligence agent operating as a propagandist adopting a pen name is that he would make himself immune to both prosecution and persecution precisely because-if he were publicly censured, reprimanded and punished for any of his literary works - it would expose the very figures who wished themselves not to be identified with the brutes and monsters of his plays.

What is evident beyond doubt is that the author of the Shakespeare plays is not only of the noble class, but subscribes to an ideology embracing peerage, caste, privilege and the entire edifice of feudal England. It makes no sense whatsoever that a commoner from the country seeking a higher status and class position would subscribe to an ideology that would conspire to keep him in the mud. This safely eliminates the Stratford man from the authorship candidacy, since he would have no good reason to promote an ideology that would disqualify him from obtaining either respect or rank within his society. In Troilus and Cressida, there is an unmistakable appeal on the part of the dramatist for the need to maintain a caste system and its hierarchies of privileges, ranks and degrees. There are repeated references to the occult beliefs of Freemasonry. Allusions to 'degree' and its importance are repeated several times. What must be stated here is that Freemasonry, which was based on the Egyptian mystery school tradition, was designed specifically to reinforce, safeguard and protect the aristocratic bloodlines in Europe, just as the Egyptian mystery schools had formerly done in Egypt. Mainly aristocrats belonged to Freemasonry at this time and would be initiated into its higher degrees in order to protect the aristocratic bloodlines as part of an orchestrated effort to maintain their hegemony, privilege and purity. To the author of the Shakespeare plays, obedience to rank and degree was so natural that it made appeal to the order of nature itself. Freemasonry, to which both Tudor princes were high initiates, as most nobles of rank would have been, had a vested interest in promoting its ideology, which Shakespeare does through the words of Ulysses:

\section{BLOCK QUOTE BEGINS}

The heavens themselves, the planets, and this center Observe degree, priority, and place,
Insisture, course, proportion, season, form, Office, and custom, in all line of order: And therefore is the glorious planet Sol In noble eminence enthron'd and spher'd Amidst the other.

(Troilus and Cressida, 1.3.85-91)

\section{BLOCK QUOTE ENDS}

To understand these lines and their significance requires some rudimentary knowledge of Freemasonry. Sol is Latin for 'Sun.' The Sol Invictus religion was the religion of classical Rome and was a Sun-worshipping cult. The Freemasonry secret society fraternity is pagan and exalts the Sun as its highest principle. The Sun is the king of the planets, so it may be said the king as the sovereign of the nation is the Sun or the Sun god, and as such is no less than God in glory. High aristocratic caste is indistinguishable from high degree in Freemasonry, since only those initiates with the most royal blood and highest noble peerage would be able to rise to the highest degrees. A higher degree Freemason would certainly have the bloodline of kings. The ideology embraced by the fraternity was that caste had to be maintained, that bloodline could not be compromised, or like metal, it would suffer debasement. Shakespeare writes that degree and rank must be adhered to lest, as Ulysses maintains, disease and disorder reign: "O! when degree is shak'd,/Which is the ladder to all high designs,/The enterprise is sick . . .” (1.2.101-103)

In a poem from his youth called, "Labour and Its Reward," Oxford, crediting himself as the author, writes, "The Mason poor that builds the lordly halls/Dwells not in them: they are for high degree. . [80]." Oxford is referring to the system of initiation in Freemasonry based on degree, which assigns privilege to those of higher rank, those of more noble blood, who are initiated into the higher degrees of the fraternity. What is clear throughout the poem is that Oxford is lamenting the fact that there are many initiates of higher degree who outrank him. As a Mason, not only is he honor bound to maintain the secrets of the order, having taken a pledge to do so, but must also comply with what higher initiates within the order demand of him. It is not at all far-fetched to suppose that Oxford had been required by his membership within Fra Rosi Cross, Freemasonry, and the British secret service-all founded by Sir Francis Bacon-to write secretly as an Invisible for purposes of personal safety as well as national security. The fact that Oxford as an author regrets the anonymity he must maintain is clear in two lines appearing near the end of the poem: "So he that takes the pain to pen the book/ Reaps not the gifts of goodly golden muse ... [81]".

While being a higher degree initiate of Freemasonry, it appears Oxford was surpassed in rank and degree by Bacon, who would have been a $33^{\circ}$ Freemason and Master of the Order, and would have 
required the lower degree initiate to write anonymously as an agent of British intelligence, initiate of Freemasonry, Fra Rosi Cross, and courtier. While Bacon was 11 years younger than Oxford, he surpassed him in rank because his favored son status with the Queen granted him higher peerage and position. Bacon was, after all, the Earl of Leicester's son, Queen Elizabeth I's beloved. Lord Oxford, unfortunately, was the son of Thomas Seymour, then Princess Elizabeth's stepfather, a pedophile and unscrupulous social climber who raped her when she was only 15 . This unnatural birth would hardly be a happy memory, and the child associated with the painful and unseemly recollection would likely suffer neglect and potentially even mistreatment, and there is some evidence that that was indeed the case.

Amazingly, according to Alfred Dodd, Bacon was not a commoner, but the secret son of Queen Elizabeth I and prince of the realm [82]. Far from being the Virgin Queen known to posterity, Dodd and other researchers believe her to have had at least three children, including Francis Bacon and Robert Devereau, the Earl of Essex. This is all substantiated by Bacon's own claims in his hidden biography embedded in cipher code within the body of his works, as discovered by Elizabeth Gallup. Excerpts from her book will be shared at length in Shakespeare Codex Volume 2. In addition, the author of Oxford: Son of Queen Elizabeth I, Paul Streitz argues that Lord Oxford is another changeling son of Queen Elizabeth and was the product of a royal rape involving her stepfather, Thomas Seymour, in which she was violated and left with child at a very tender age [83]. To prevent a scandal, William Cecil arranged for the birth to take place in the country and the child was later farmed out as a changeling child to the home of the 16th Earl of Oxford. The fact that Lord Bacon and Lord Oxford were actually both changeling children of Queen Elizabeth would make them half-brothers. The incident involving Princess Elizabeth and Thomas Seymour is also referred to by Francis Bacon in an embedded cipher history contained within A Treatise on Melancholy written by Bacon under the pen name, Thomas Bright:

\section{BLOCK QUOTE BEGINS}

Rather would a slowly approaching death bee desir'd, or haste'd to summon us quicklie, then that we now weaken in our great undertaki'g of writing out - in our secrete but playne manner of transmitti'g, our history, as hath here been sayd in our other Cyphar; also a most full and compleat storie of this so-styl'd maiden queene, her marriage, when prisoner of the Tower at command o' Queene Mary, and her prior and love profess'd for Seymour, a man many a yeare elder, yet not greatly wiser then th' willfull princesse.

He, by disownei'g the child, subjected the princely heart to ignominie, and co'pelled Elizabeth to murder this infant at the very first slight breath, lest she bee openly sham'd in Court, inasmuch as King Edward was intollerant of otheres foibles, whilst partiall to his owne [84].

\section{BLOCK QUOTE ENDS}

The embedded cipher history provides an account of the scandalous affair between Princess Elizabeth and Thomas Seymour, which produced a child. It is a shame that the cipher history ends here and offers no further details. The child alluded to could be none other than the changeling child that became Edward de Vere, the Earl of Oxford. Does this mean Bacon was kept unaware of de Vere's circumstances of birth or that the cipher revealing this fact has not yet come to light? We may never know.

As for Tudor princes Oxford and Bacon, their patriotic duty would have required them to be spiritual martyrs in the cause of nation-building. They would not be permitted to enjoy the fruits of their labor. They would be writing clandestinely as intelligence men, dispatched on espionage missions to the Continent under the protection of diplomatic immunity, while covertly gathering intelligence on the royal courts of other lands, and then returning to England to dramatize what they had learned abroad as part of a state propaganda operation. They would also appropriate what had become institutions in Italy, including the Petrarchan Sonnet, the masterpieces of Ovid, Plutarch and others, superseding them in mastery and genius, exacting a cultural coup on the Continent that would leave England sitting prettiest, while holding the coveted prize of the greatest writer in European history in the personage of their Shake-speare, and what would be even worse medicine for the Continental Europeans to bear would be the fact that this peerless writer would be passed off as a mere 'commoner,' a mere hick from the country. This was the coup de grace and if the truth be known the greatest ruse of all, since the Bard was anything but a commoner, but William Shakespeare, Gent.

\section{Real-life Background for Hamlet}

Hamlet is regarded as the most autobiographical of the Tudor plays. It is full of allusions to characters of the Court. Prince Hamlet is the Earl of Oxford himself, whose own father died when he was only 12 , and whose specter very likely haunted him for the rest of his life. Oxford's mother remarried with "unseemly haste" following the death of his father, which gives context to Hamlet's rage at his mother, Queen Gertrude, in her bedchamber for her adulterous and hasty marriage to his uncle Claudius. Polonius is certainly modeled after William Cecil, also known as Lord Burghley, a title given to him by the Queen. He was Oxford's guardian, the man who raised him following his adopting father, the 16th Earl of Oxford's death and his mother's subsequent remarriage. Cecil later became his father-in-law, after an arranged marriage between Oxford and Lord Burghley's 
daughter was agreed to by the Queen. Oxford is known to have loathed his guardian, later father-in-law and to find the man utterly contemptuous. Laertes represents Burghley's son, Robert Cecil, another enemy of both Tudor princes. Horatio is suggested by Sir Horatio Vere, who was Oxford's first cousin and close friend. The Ghost of Hamlet's Father probably has an autobiographical match in the Earl's adopting father, the 16th Earl of Oxford, who died in his youth, and is believed to have been poisoned. Queen Gertrude appears to be a composite of Oxford's adopting mother and Queen Elizabeth I, whose consort, the Earl of Leicester, is the model for King Claudius. In Ophelia, the author of Hamlet is believed to be personifying Oxford's wife, Anne Cecil, daughter of Lord Burghley. Old Fortinbras is really Mary Stuart, Queen of Scots, while Young Fortinbras, the son, is a representation of James VI of Scotland, who would become James I of England. In his embedded cipher history, Francis Bacon claims authorship of Hamlet. Despite this fact, there are reasons to question whether the earlier quarto versions of Hamlet may have been the work of Oxford, with Bacon refining, polishing and greatly expanding the masterpiece following the earl's death. However, evidence to support this theory will be reserved for volume 2 of Shakespeare's Codex.

\section{BLOCK QUOTE BEGINS}

Prince Hamlet $=$ Edward de Vere, the Earl of Oxford Queen Gertrude $=$ Composite of Oxford's mother and Queen Elizabeth I

King Claudius = Queen Elizabeth's Consort, the Earl of Leicester

Polonius = William Cecil, Lord Burghley

Laertes $=$ Burghley's son, Robert Cecil

Horatio $=$ Horatio Vere, Oxford's first cousin

Ghost of Hamlet's father = the Earl's father by adoption, the 16th Earl of Oxford

Ophelia = Oxford's wife, Anne Cecil, Lord Burghley's daughter

Old Fortinbras = Mary Queen of Scots

Young Fortinbras = James VI of Scotland, James I of England

\section{BLOCK QUOTE ENDS}

Following the death of the 16th Earl of Oxford, the 12-year-old Edward became a royal warda royal subject raised with special provision by the Crown - in the home of Lord Burghley. In December 1571 at age 21, Edward was intended to wed Lord Burghley's 16-year-old daughter, Anne Cecil. This corresponds with Prince Hamlet's intended marriage to Ophelia, Polonius's daughter. Following Anne Cecil's later death, the couple's children also become wards of Lord Burghley. Hamlet's words are never insignificant in relating to the life of the author. It is the most autobiographical of the plays depicting the lives of the Tudor princes in that it matches Oxford's life precisely.
The play is intended to set things that have gone to pot to rights. The play in large part seems to be directed spitefully at Oxford's adopting mother, but also his biological mother, the Queen. Bacon's mother Anne Bacon could certainly not be the target, since she was a devoted wife and mother and much beloved by her adopted son, Francis. The play is a disguised indirect attack on the Court of England. By setting the play abroad in Denmark, the critique of the English Court is veiled, and the Court figures it satirizes receive their chastisement through black comedy. "Something's rotten in Denmark" really refers to all that is rotten in England. The playwright seems to suggest that England, disguised as Denmark, has fallen under a curse, so that the current of the times is running awry: "The time is out of joint. O cursed spite/That e'er I was born to set it right." (Hamlet, 1.5.189-190) The illegitimate Tudor princes must have felt that the times were indeed out of kilter. At a time when the traditional Catholic and feudal character of their nobility had been uprooted by Protestantism and the rising merchant class, the Tudor princes must have felt that the body politic of their beloved England had been infected by a deadly canker that they felt duty bound to excise. How did they resolve to set things right? Well, let's examine Hamlet's "mouse-trap" and see how it relates to Tudor prince's own "mouse-trap" and which mice they intend to corner.

It is quite probable that the Tudor princes intend through Hamlet what Prince Hamlet intends through the play-within-the-play, as "The play's the thing/Wherein I'll catch the conscience of the King." (Hamlet, 2.2) The Queen is actually not implied by the reference to the monarch King, but rather her consort Robert Dudley. The fact is that the Queen could not marry Dudley publicly due to the scandal that would have erupted in the wake of his wife's suspicious death. Hence, they had to marry secretly in the country to avoid a public backlash. In addition, Alfred Dodd informs us that they shared adjoining bed chambers in the palace and that there was a secret panel door that could be slid to one side to allow for clandestine meetings by the occupants beyond the prying eyes of their servants and public.

Imagine the reaction, if Queen Elizabeth and Lord Robert were forced in like fashion to that of Queen Gertrude and King Claudius to sit through a performance of "The Mouse-trap," the murder of Gonzago conceived as a probable reenactment of the assassination the Queen and Dudley had ordered in order to clear Leicester's path to the throne of England. In all likelihood, it would have pricked Leicester's conscience in much the same way the murder scene played on King Claudius's conscience. Come to think of it, the murder of King Duncan would have done much the same were Leicester to have sat through a performance of Macbeth. In both cases the mirror of 
verisimilitude would have been held up to nature, mimicking perfectly his motives and heinous actions.

\section{BLOCK QUOTE BEGINS}

WE BEGIN WITH THE PLAY-WITHINTHE-PLAY FROM HAMLET AND THE REACTION OF KING CLAUDIUS TO THE PLAY.

PLAYER QUEEN: Nor earth to me give food, nor heaven light!/Sport and repose lock from me day and night!/To desperation turn my trust and hope! An anchor's cheer in prison be my scope!/Each opposite that blanks the face of joy/Meet what I would have well and it destroy!/Both here and hence pursue me lasting strife, If, once a widow, ever I be wife!

HAMLET: If she should break it now!

PLAYER KING: 'Tis deeply sworn. Sweet, leave me here awhile;/My spirits grow dull, and fain I would beguile/The tedious day with sleep.

The Player King sleeps.

PLAYER QUEEN: Sleep rock thy brain,/And never come mischance between us twain!

The Player Queen takes her exit.

HAMLET: Madam, how like you this play?

QUEEN GERTRUDE: The lady protests too much, methinks.

HAMLET: O, but she'll keep her word.

KING CLAUDIUS: Have you heard the argument? Is there no offence in ' $t$ ?

HAMLET: No, no, they do but jest, poison in jest; no offence I' the world.

KING CLAUDIUS: What do you call the play?

HAMLET: The Mouse-trap. Marry, how? Tropically. This play is the image of a murder done in Vienna: Gonzago is the duke's name; his wife, Baptista: you shall see anon; 'tis a knavish piece of work: but what o' that? your majesty and we that have free souls, it touches us not: let the galled jade wince, our withers are unwrung.

(Hamlet, 3.2)

NOW IMAGINE HOW THE QUEEN AND HER CONSORT MIGHT REACT TO A PERFORMANCE OF HAMLET IF THEY WERE SEATED IN THE AUDIENCE. THIS FICTIONAL REENACTMENT IS MEANT TO ILLUSTRATE THE POSSIBLE RESPONSE.

Queen Elizabeth gives her consort a sidelong glance.

ROBERT DUDLEY: (Whispers) What is our Bard up to this time?

QUEEN ELIZABETH: (Whispers) Methinks nature holdeth a glass up to life.

ROBERT DUDLEY: I believe they call it deja vu when something once seen shows its face a second time.

QUEEN ELIZABETH: Like a bad penny.

ROBERT DUDLEY: And to think some paid a penny to get in.
QUEEN ELIZABETH: Fit payment for the cheapness of human affairs.

ROBERT DUDLEY: Not so. Some affairs cost one dear.

NOW BACK TO HAMLET, WHERE THE PRINCE IS NOW EXPLAINING THE PLOT TO OPHELIA.

Lucianus enters during the play-within-the-play.

HAMLET: This is one Lucianus, nephew to the king. OPHELIA: You are as good as a chorus, my lord.

HAMLET: I could interpret between you and your love, if I could see the puppets dallying.

OPHELIA: You are keen, my lord, you are keen.

HAMLET: It would cost you a groaning to take off my edge.

OPHELIA: Still better, and worse.

HAMLET: So you must take your husbands. Begin, murderer; pox, leave thy damnable faces, and begin. Come: 'the croaking raven doth bellow for revenge.

LUCIANUS: Thoughts black, hands apt, drugs fit, and time agreeing;/Confederate season, else no creature seeing; Thou mixture rank, of midnight weeds collected,/With Hecate's ban thrice blasted, thrice infected, Thy natural magic and dire property,/On wholesome life usurp immediately.

He pours the poison into the sleeper's ears.

HAMLET: He poisons him I' the garden for's estate. His name's Gonzago: the story is extant, and writ in choice Italian: you shall see anon how the murderer gets the love of Gonzago's wife.

OPHELIA: The king rises.

HAMLET: What, frighted with false fire!

QUEEN GERTRUDE: How fares my lord?

LORD POLONIUS: Give o'er the play.

KING CLAUDIUS: Give me some light: away!

ALL: Lights, lights, lights!

(Hamlet, 3.2)

\section{BLOCK QUOTE ENDS}

For Prince Hamlet, the play-within-the-play is intended as a mouse-trap-from whence it gets its name - meant to ensnare and ensconce his uncle and stepfather, King Claudius. Prince Hamlet makes his intentions clear with the words, "The play's the thing/Wherein I'll catch the conscience of the King." Suppose by staging the play, the Earl of Oxford was employing indirect communication in order to expose what was rotten in the state of England and not Denmark. First, let's try to understand "The Mousetrap" from Prince Hamlet's perspective. Prince Hamlet tells us that he wishes to set his play "tropically," to the south, choosing the Court of Geneva, Switzerland as a disguise for the Court of his own homeland. In truth, it is England that is due south of Scotland, just as Denmark is due south of Norway. We see that a curse seems to have befallen the Court of Denmark, as a result of a murder committed by the royal house against one of its own members. The curse results in there being no claimant, no royal heir to inherit the throne 
within the Hamlet royal line. Hence succession must go to the prince of the land to the north, which in the play is represented as Norway, but which is really meant to represent the kingdom due north of England, which is Scotland. It is a clever analogue. The question is, if there is something rotten in England, represented by something rank in Denmark, what is it? It seems that a royal murder is what is at issue as much for England as for Denmark.

Suppose the plays, if correctly attributed to a courtier close to the throne, were commentaries on affairs of court by an insider, in which highly placed court figures were lampooned by the dramatist, a dangerous business but somewhat less daring for a playwright who was immune to prosecution. The reason for this is that the author was anonymous and had to remain so. Were he to have suffered punishment for any of his covert whistleblowing on affairs of state, the people he was lampooning, cautioning or chastising in his plays would also be publicly exposed, which would cause them no end of embarrassment. Another reason was that shooting the messenger would only draw further attention to the message, thus implicating the figures of court and even the throne itself for some type of wrongdoing. It would be rather absurd to prosecute a man for no apparent reason, but to bring charges against a man, who being thus identified as Bacon or Oxford, for instance, writing under a pen name, would immediately expose several figures of the Courtincluding Queen Elizabeth, Robert Dudley, Earl of Leicester, and Lord Burghley-to scandal and disgrace. "My name be buried where my body is," says the author of Shake-speares Sonnets, an author who well knew the importance of maintaining obscurity. In addition, there was a need for the author(s) to protect themselves from charges of libel, treason and other dangers.

Hamlet is rather obviously parodying the language and attitudes of Lord Burghley in the platitudes of Polonius. In the early version of Hamlet, Burghley was called Corumbis from the Latin Cor ambis, meaning "two-hearted," a blatant attack against Burghley's motto, Cor unam via Una, meaning "one heart, one way." Only a dramatist with royal protection or operating under complete public anonymity could have gotten away with a slight of that kind against someone of such high social rank [85].

Hamlet is so deeply autobiographical. In this play, we have featured someone who is a nobleman by birth, and a playwright by vocation. When confronted by a deep personal crisis, he immediately adopts the motto that "the pen is mightier than the sword," and decides to confront the problem and the people who caused it by writing an autobiographical play about it, a-play-within-a-play that imitates life so exactly as to hold a mirror up to life itself. Even in his idle moments, he is constructing verse, living and breathing poetry.
Like the Tudor princes, particularly Lord Oxford, he is deeply disaffected with the life of the court, and most at home when in the company of common players, though he is elevated above them as a patron instead of being one of their brethren. On the weight of evidence provided by the plays and poems as a whole, as well as the deeply autobiographical play Hamlet, a perceptive student of Shakespeare would have to conclude that he was of such high birth that he would likely be placed in the company of the royal retinue, someone so at odds with his birth and station in life, that he is railing against the rules and conventions of the class within which he feels stiflingly trapped. In the Henry plays, he resembles Prince Hal as closely as he does Hamlet. It is simply autobiographical of a happier and less tragic time in his youth. Just as Prince Hal finds escape in the company of Eastcheap and Falstaff, so Hamlet finds relief in the company of his common players who take up his parts. The playwright finds release and relief in the composition of poems and plays, finding the greatest breath of fresh air in being among the acting companies, the other side of the double life that he seems to have led. In fact, Shake-speares Sonnets do make it painfully clear that the author(s) are of particularly high social rank, but have lost caste, and have adopted a disguise in order to continue life as a writer. Like most individuals engaged in the breaking of social law, the author(s) require a disguise to hide behind like Robin Hood, Zorro, The Three Musketeers, Superman, Batman, Spider-Man or any of their more modern equivalents. Examining all the members of Elizabeth's Court, there is no one who so exactly matches the personage of Prince Hamlet than the Earl of Oxford, the illegitimate son of Queen Elizabeth I. As previously noted, Sigmund Freud comes to the same conclusion after attempting to match Hamlet's psychological profile with many of the prominent members of the English aristocracy. Subjecting the various members of the English Court to his psychoanalytic gaze, Freud concludes that the psychological profile of Hamlet matches Oxford more closely than any other Englishman of the time.

One major anomaly in Hamlet worthy of our attention due to sheer idiosyncrasy is the fact that the prince shows no remorse over the slaying of Polonius, dismissing it out of hand without the least regard. The real-life Hamlet did not kill the real-life counterpart of Polonius, namely, Lord Burghley. He did not skewer the old counselor with a sword but with his rapier wit and his pen. The Tudor princes killed him with the written word, lampooning him to the point of mortification and death. The act is therefore malicious, but not murderous, so it makes sense that the prince should ask for Laertes's forgiveness with such offhandedness and apparent ease: "Give me your pardon, sir; I've done you wrong;/But pardon't, as you are a gentleman." (Hamlet, 4.2) This is a logical statement to make to one whose father you have insulted and maligned, but surely not one whom you have 
slaughtered, especially in light of the fact that he has also driven his sister, Ophelia, to madness and suicide. The author(s) are making an apology through the fictional Hamlet to a living relation to whom he wishes to make peace. After slaying Polonius, who represents Lord Burghley in real life, Hamlet tells the King: "A certain Convocation of politic worms are e'en at him,/Your worm is your own emperor for diet." (Hamlet, 4.2) In point of fact, Burghley was always reminding people that he was born during the Diet of Worms, which Emperor Charles V had opened and at which church reformer, Martin Luther, had defended his doctrines. When Prince Hamlet calls Polonius "a fishmonger," he is referring to Burghley's having put a bill through Parliament that made Wednesday and Friday meatless days in an attempt to boost the fisheries. The Catholics called this "Cecil's Fast" after the counselor.

The slaying of Polonius parallels an actual event that occurred in the Burghley home in Oxford's youth. Lord Oxford wounded a servant, concealed behind a tapestry, for spying on him. The victim died, but Oxford was exonerated, undoubtedly because the slayed man was only a servant, and their class differences set them apart enough to make it comparable to a master slaying his pet. Whether his guardian, William Cecil, actually dispatched this man to spy on Oxford is unverifiable, but there are strong suspicions among scholars that this was so. The spying taking place in Elsinore Castle would tend to support the view that a lot of activity of this kind was taking place in the Burghley home. This spying incident and resulting homicide is recreated in Hamlet [86].

Burghley wrote a volume called Certaine Preceptes for his sons, which parallel the lines Polonius speaks to Laertes in Hamlet prior to Laertes's departure. Burghley's volume was not published until years after he, Oxford and Will Shakspere had passed on. What this suggests is the author of Hamlet must have had an intimate association with the author of the book of proverbs, and must have viewed the contents in manuscript form while the author was still alive in order to produce the parody. Burghley writes in Certaine Preceptes:

\section{BLOCK QUOTE BEGINS}

And that gentleman who sells an acre of land, sells an ounce of credit. For gentility is nothing but ancient riches. Let thy hospitality be moderate; \& according to the means of the estate; rather plentiful than sparing, but not costly. Beware of surety for the best friends. He that payeth another man's debt, seeketh his own decay. Be sure to keep some great man thy friend, but trouble him not for trifles [87].

\section{BLOCK QUOTE ENDS}

In Hamlet, Polonius is given the following lines to parody such precepts as those appearing in the preceding lines:

\section{BLOCK QUOTE BEGIN}

And these few precepts in thy memory

Look thou character. Give thy thoughts no tongue, Nor any unproportion'd thought his act. Be thou familiar, but by no means vulgar: Those friends thou hast, and their adoption tried. Grapple them unto thy soul with hoops of steel; But do not dull thy palm with entertainment Of each new-hatch'd, unfledg'd comrade. Beware Of entrance to a quarrel; being but in,

Bear't that th' opposed may be aware of thee. Give every man thine ear, but few thy voice; Take each man's censure, but reserve thy judgement. Costly they habit as thy purse to buy,

But not express'd in fancy; rich in gaudy; For the apparel oft proclaims the man, And they in France of the best rank and station Are most select and generous, chief in that. Neither a borrower or a lender be; For loan oft loses both itself and friend, And borrowing dulls the edge of husbandry. This above all - to thy own self be true, And it must follow as the night the day, Thou canst not then be false to any man. (Hamlet, 1.3, 543-567)

\section{BLOCK QUOTE ENDS}

Oxford, who was one of the few people to actually know Burghley intimately enough to know his habits, comings and goings, and way of thinking, is clearly parodying the man's turn of phrase. The words on friendship show Burghley's attitudes toward friendship in the most mocking terms, alluding to the fact that he had an instrumental view of friendship, used people, and was not highly possessive of friendship. $\mathrm{He}$ also mocks Polonius's warnings to Laertes to avoid a life of pleasure, and not to consort with strangers and people untried by friendship. He also warns Laertes against rashness and quarrelling. In addition, he admonishes him not to be foppish or excessively extravagant in dress. And finally, he warns him against a life of dissipation, where one is careless with money. Every one of these warnings to Laertes match Burghley's warnings to his own son, Robert, to avoid going down the same path as the Tudor princes, Bacon and Oxford, both of whom experienced problems with debt. Oxford consorted with men of the theater, commoners that Lord Burghley would not have approved of. Oxford was notoriously hotheaded and given to quarrelling. He was extravagant with dress and was known as the Italianate Englishman for his preference for Italian fashion. He was also notoriously careless with money, being forced to sell off several of his estates due to bad investments and lavish spending. This would have made him poor at husbandry as 
Burghley alleges in the personage of Polonius. The author appears to be mocking Burghley's overly conservative, hypocritical stances in virtually every scene featuring Polonius, in perfect mimesis, holding a mirror up to the nature of the man as an exact replica.

Oxford's relationship with Lord Burghley's daughter, Anne Cecil, resembled Hamlet's to Polonius's daughter, Ophelia, remembering that Polonius is Burghley in real life. In addition, Oxford's mother remarried just a few months after her husband's death, just as Queen Gertrude, Hamlet's mother had done. Robert Dudley, the Earl of Leicester, the Queen's lover and chosen suiter, is widely believed to have murdered his wife, Amy Robsart, to clear the way for him to marry Elizabeth. A plot to accomplish this had been laid involving poison, when news of the lady's mysterious death spread in September 1560. This was followed by a report that she had broken her neck as the result of an unfortunate fall down the stairs in her own home. The verdict of history is that her husband, the Earl of Leicester, was not to blame. However, many people then and now doubt the official story's validity. Some were even doubtful of the Queen's innocence in the affair. The scandal that emerged was international in scope. Elizabeth, however, only showed her suiter more favor by bestowing on him the castle of Kenilworth and other valuable estates, while conferring upon him the title of Earl of Leicester in 1564. He was then given possession, at the behest of Elizabeth, to the bulk of the estates that Lord Oxford had been forced to forfeit as the result of debt, just as Claudius, who cleared his way to the throne through marriage to Queen Gertrude, acquired the kingdom to which Prince Hamlet had been the natural heir, thus usurping the throne and the privileges that went with it from the natural successor. But Claudius is probably a composite character also representing Oxford's stepfather, Charles Tyrell. While there is no evidence that Tyrell had murdered Oxford's father in a perverse and twisted plot to wed Oxford's mother as Claudius had done in Hamlet, he bore the identity of a murderer nonetheless, insofar as he shared the name Tyrell, whom Richard III had enlisted to kill his nephews, the royal princes, to clear his way to the throne. It was part of the family history, since the 13th Earl of Oxford had presided over the trial of Robert Tyrell. To Edward, a young boy of 12, it would have seemed that Charles Tyrell not only had the stench of murder in his name, but had also murdered his father's memory.

It is Hamlet himself who says that the aim of stage-playing is "to show . . the very age and body of the time his form and pressure." (Hamlet, 3.2) It is Hamlet too who calls the players "the abstracts and brief chronicles of the time." (Hamlet, 3.2) Implicit in these lines is the fact that the dramatist wishes to hold a mirror up to nature with such proximity that the "age and body of the time" are reflected so exactly as to be a proper portrait of the Elizabethan Court.
Hamlet's most trusted friend and confidante is Horatio. How fitting since one of Oxford's favorite cousins was Horatio de Vere, who was 15 years his junior. Horatio took care of Oxford's son, Henry, during one of Oxford's military campaigns on the European Continent. When Oxford was in his 20s, he even wanted to make Horatio and his brother the heirs to his earldom. Hamlet's dying words to Horatio strike a chord with anyone who adheres to the Oxfordian authorship. The dying Hamlet entreats Horatio to tell the truth about the events depicted in the play. If Hamlet's words are also taken to represent Oxford's anguish over the fact that his good name may never be redeemed by association with extraordinary literary achievement, then his words carry a devastating appeal to the living to defend his good name. "Horatio," Hamlet appeals, "I am dead. Thou livest. Report me and my cause aright to the unsatisfied." Out of loyalty, Horatio tries to join Hamlet in death by drinking the poison that has killed the Queen, but Hamlet stops him, entreating:

\section{BLOCK QUOTE BEGIN}

O God, Horatio, what a wounded name,

Things standing thus unknown, shall live behind me. If thou didst ever hold me in thy heart, Absent thee from felicity a while,

And in this harsh world draw the breath in pain

To tell thy story.

(Hamlet, 5.2.310-314)

\section{BLOCK QUOTE ENDS}

Some critics have objected to the Oxfordian authorship on the grounds that Oxford was too often guilty of reprehensible and deplorable conduct. When has the production of art ever been reconcilable with upstanding moral conduct and respectable behavior? The history of western art and literature is full of profligates and unrepentant reprobates like Byron and Shelley. In his defense, at least it can be said that Oxford repented. In play after play, he shows himself to be penitent, censoring himself without needing to invite the condemnation of the world. And if the author of these plays is half-brother Bacon, then it seems that Bacon is writing as Oxford's apologist, setting to rights his brother's ill conduct by having him adopt a penitent and remorseful stance. The sins charged against Oxford are hardly cause for disqualifying him as the author; they tend rather to strengthen his candidacy by matching him with the penitent author that begs forgiveness from the people he offended in life like his wife, Anne Cecil. Oxford seems to be his own protagonist in play after play, the tragic figure with the tragic flaw that results in his fall from grace. Oxford is repudiated for his treatment of his wife, Anne Cecil, as Hamlet is scorned for contributing to Ophelia's insanity and suicide, and Othello is reproved for murdering Desdemona in a fit of jealousy, and Angelo for his unfair rebuke of Mariana in Measure of Measure, and Bertram for callously spurning Helen in All's Well That 
Ends Well, and Leontes for his ruthless condemnation of Hermoine in The Winter's Tale, and Postumus for his heartless abandonment of Imogen in Cymbeline, etc [88].

Oxford's father, the 16th Earl of Oxford, maintained a troupe of players who often put on entertainments in the banquet hall of Castle Hedingham. It was a family tradition. Before 1509 , Henry VII had rewarded the Lords of Oxford, Northumberland and Buckingham for staging lavish productions continued for Henry VIII. The Earl of Oxford's players, as was the custom of players of the 16th century, toured the country during the summers and at other times of the year. Reporting a century after Shakespeare's death, Dr. John Ward alleged that Mr. Shakespeare frequented plays in his youth. If entertainments were a regular event at Castle Hendingham, as has been recorded, then Hamlet's sportive staging of the play-within-the-play at Elsinore Castle may be of autobiographical import. Certainly, the young earl is known to have enjoyed participating in such revels at the castle in his youth. This may account for Hamlet's reminiscences over the court player Yorick in the graveyard scene in Hamlet [89].

\section{BLOCK QUOTE BEGIN}

Alas, poor Yorick! I knew him, Horatio: a fellow of infinite jest, of most/Excellent fancy: he hath borne me on his back a thousand times . . Here those lips that I have kissed I know not how oft. Where be your jibes now? Your gambols? Your songs? Your flashes of merriment, that were wont to set the table on a roar.

(Hamlet, 5.1)

\section{BLOCK QUOTE ENDS}

Whether as playwright or director, Oxford did participate in the staging of the Shakespeare plays. In play after play, the title pages announce, "As it hath been publicly acted by the Right Honourable Lord Chamberlaine his servants." We can find the origin of Hamlet's delight in tournaments and his duel with Laertes in Oxford's own exploits. Oxford's love of jousting and other tournaments is alluded to in several plays. One tournament in particular is recorded in the annals as having taken place in May 1571. The challengers were Oxford, Charles Howard, Sir Henry Lee, and Christopher Hatton. The defendants were Lord Stafford, Thomas Cecil (Burghley's eldest son), Robert Colsell, Thomas Coningsby, Oxford's friend Thomas Begingfield, and Thomas Knyvet (Anne Vavasor's uncle and the apparent model for Tybalt in Romeo and Juliet). The grand prize at the tournament would be awarded to the contestant who "breaketh most spears, as they ought to be broken," delivering blows of the prescribed kind, or "beareth a man down with the stroke of a spear." A scoring sheet of the tournament is extant that shows that Sir Henry Lee, the Queen's champion, ran over 51 courses in the tilt against seven defendants and broke 32 lances. The Earl of Oxford did even better, breaking as many lances, while also scoring three "Attaints," or direct hits to the head or breast." Oxford was only 21, while the other contestants were much older and more experienced. It was an amazing feat for an Olympian-level athlete, showing that his athletic and adventuring life were totally up to the task of writing about larger-than-life events and personages. There is a translation of a Latin account of Oxford's horsemanship skills by Giles Fletcher, a contemporary of Oxford, that attests to his skills with great aplomb:

\section{BLOCK QUOTE BEGIN}

But if any time with fiery energy he should call up a mimicry of war, he controls his foaming steed with a light rein, and armed with a long spear rides to the encounter. Fearlessly he settles himself in the saddle, gracefully bending his body this way and that. Now he circles round: now with spurred wheels he rouses his charger. The gallant animal with fiery energy collects himself together, and flying quicker than the wind beats the ground with his hooves, and again is pulled up short as the reins control him [90].

\section{BLOCK QUOTE ENDS \\ Oxford's Juliet}

While estranged from his wife, Oxford began an affair with the Court beauty, Anne Vavasor, one of the Queen's maids of honor. Anne was just shy of 20years-old at the time and Oxford was utterly smitten with the seductress. The lovers conceived a son as a result of their tryst. They were rewarded for their indiscretions with a three-month stay in the Tower of London. Oxford had been in high favor with the Queen until this incident. Rosaline, a character referred to at the beginning of Romeo and Juliet probably refers to the "Rose line" or the "line of the Rose," which is the line of the Tudor family represented by the red rose symbol. Hence, the character Rosaline, who Romeo is in love with prior to his love affair with Juliet, most likely refers to Queen Elizabeth I. As controversial as it may be, many Elizabethan and Shakespearean scholars of the Oxfordian school of Shakespeare criticism, believe that Oxford had an incestuous relationship with his mother, the Queen, and that they also produced a son through their love tryst, who became Henry Wroithelsey, the Earl of Southampton, to whom Oxford is thought to have dedicated the Sonnet poems.

While it is extremely contentious to refer to this theory in polite society, the fact is that history and historical incident are not politically correct. Even in our own time, the reality of what goes on behind the scenes of political life is quite at odds with the public façade of respectability. Elizabethans, while known for their discretion and tact, were somewhat less discreet and tactful than their modern-day counterparts, quite simply because they were not subject to nearly as much public scrutiny and publicity. In addition, court officials like Oxford, while subject to the censure and 
chastisement of the Queen and her Court for any wrongdoing, were largely insulated from the shame of scandal among the wider public.

In addition, incest within the royal family, while condemned by the Judeo-Christian moral ethos, has been widely practiced down through the ages, largely due to the fact that royals wished to keep their bloodlines as purely royal as possible. There are many historical examples to support this, such as the founding emperor and empress of China-Fuxi and Nawa-who were brother and sister as well as husband and wife. Readers shouldn't be shocked because it was no different in Egypt, where the Great Royal Daughter (first-born daughter of the Pharaoh) traditionally married the first-born son of the Pharaoh. With a longstanding tradition of this kind, it is easy to understand why congenital diseases such as hemophilia-which tend to run rampant in royal families particularly - have occurred historically as a result of genetic inbreeding within royal lines.

Whether Queen Elizabeth I was experiencing romantic jealousy in addition to taking offense at having her royal retinue violated by unseemly scandal, there is no question that she was incensed. In fact, it is probable that the only reason Oxford kept his head and was not condemned to death was because he was the Queen's son as well as a lover, giving her reasons for being doubly fond. Of course, this is offensive to conservative society, but history and historical circumstances are not politically correct, so readers should best get used to it. A good historian does not impose his moral sense of what should be respectable on his review of history. This demonstrates unacceptable bias and a lack of objectivity. At any event, the Queen, always outraged by any love dalliances between her courtiers and her maids of honor, was highly displeased. The incident is recorded by Sir Francis Walsingham in a letter dated March 23:

\section{BLOCK QUOTE BEGIN}

On Tuesday at night Anne Vavasor was brought to bed of a son in the maidens' chamber. The E. of Oxeford is avowed to be the father, who had withdrawn himself with intent, as it is thought, to pass the seas. The ports are laid for him and therefore if he hath any such determination it is not likely that he will escape. The gentlewoman the selfsame night she was delivered was conveyed out of the house and the next day committed to the Tower. Others that have found any way party to the cause have also been committed. Her Majesty is greatly grieved with the accident, and therefore I hope there will be some order taken as the like inconvenience will be avoided [91].

\section{BLOCK QUOTE ENDS}

What the letter reveals in particular is the Queen's intolerance towards any sexual involvement with her maidservants. It was a violation of her privacy and dignity as Queen in addition to showing the height of disregard for her station and position as Queen. So incensed was Her Royal Majesty in fact that she issued an arrest warrant for the mother of the child the night of her delivery, endangering the life of both mother and child in the process. Not only that but she ordered that Anne Vavasor be confined to the Tower along with anyone suspected of being party to the affair.

An interesting historical footnote is the fact that the child would bear the name Vere, without the "de," principally because he was conceived out of wedlock and could therefore not be legitimately considered a member of the aristocratic House of Vere. The son, as befitting a Vere, would distinguish himself in battle and would also assume a seat in Parliament.

Due to this most grievous offense, Oxford was confined to the Tower for a total of two-and-a-half months. The Queen must have taken pity upon him or otherwise experienced some pressure to release him, for he was set free from the Tower on June 8. While having been released from captivity, de Vere continued to be kept under house arrest for some time. This is unorthodox even for the Queen and suggests that a power struggle of some kind threatened between the Queen and her son. Why would that be? Had he committed some offense in addition to this massive sexual indiscretion that might have been considered treasonous? Could the play Romeo and Juliet be the source of the Queen's disquiet? The fact is that the play matches far too closely the circumstances in Oxford's own life at the time of this scandal, and like Hamlet is autobiographical to the point of Oxford practically bearing his entire soul. In Verses Made by the Earl of Oxford, we have his Echo Verses, in which he continually plays with his own name:

\section{BLOCK QUOTE BEGIN}

O heavens! Who was the first that bred in me the fever? Vere.

Who was the first that gave the world whose fear I wear for ever?

Vere.

What tyrant, Cupid, to my harm usurps the golden quiver? Vere.

What wight first caught his heart and can from Bondage it deliver?

Vere.

Yet who doth most adore this wight, of hollow caves tell true? You.

What nymph deserves his liking best, yet doth in sorrow rue? You.

What makes him not regard good will with some regard of ruth?

Youth.

What makes him show besides his birth, such pride and such untruth?

Youth. 
May I this favour match with love, if he my love will try? Ay.

May I requite his birth with faith? Then faithful will I die. Ay.

And I who knows this lady well,

Said, Lord how great a miracle,

To hear how Echo told the truth,

As true as Pheobus's oracle [92].

\section{BLOCK QUOTE ENDS}

Oxford refers to the 'wound,' whose fear he must wear 'for ever.' Notice that 'forever' is separated into two words to highlight the name 'Vere'? This conveys the fact that Oxford must bear the wound because he is a Vere, just as Romeo must bear his wounds because he is a Montague. This is an obvious allusion to the fact that Oxford was wounded by Anne Vavasor's uncle in a duel because he bore the name Vere. In fact, the two families were involved in a feud because of Oxford violating the gentlewoman's good name and virtue through his scandalous extramarital affair.

The use of the word 'will' as in 'good will' refers to 'Good Will Shakespeare,' but it also denotes the future tense, conveying a pun-like wordplay as well. Thus "May I requite his birth with faith?" refers to the illegitimate son conceived as a result of their love affair. "Then faithful will I die?" refers to the fact that if he denies ownership of the illegitimate son, then "faithful will" he dies, since he will die in obscurity with no heirs born to him or of his creation whatsoever. Instead, he will die 'faithful will' as in "Faithful Will Shakespeare." As Anne Vavasor awakens the echo in the "hollow caves," which repeats the name "Vere," so Juliet will "tear the cave where Echo lies . . . with repetition of my Romeo's name." It is the same image, same allusion, same poetic device employed by the same writer in both the poem and the poetic verse from the play.

The diary of a clergyman for March 3, 1582 records the altercation that took place between Oxford and Anne Vavasor's uncle Thomas Knyvet:

\section{BLOCK QUOTE BEGIN}

My Lord of Oxford fought with Master Knyvet about the quarrel of Bessie Bavisor, and was hurt, which grieved the Lord Treasurer the more for the Earl hath company with his wife since Christmas [93].

\section{BLOCK QUOTE ENDS}

"Bessie Bavisor" was in fact Anne Vavasor and Master Knyvet was her uncle Thomas. The clergyman is referring to the fact that Oxford, who had been estranged from his wife for the space of five years, is now back with her, while the affair with his mistress has resulted in the birth of a child out of wedlock at the most delicate of times. We learn more about the altercation in a letter of March 17 written to Anthony Bacon:

\section{BLOCK QUOTE BEGIN}

In England of late there hath been a fray between my Lord of Oxford and Master Thomas Knyvet of the Privy Chamber, who are both hurt, but my Lord of Oxford more dangerously. You know Master Knyvet is not meanly beloved in Court, and therefore he is not likely to speed ill whatsoever the quarrel may be [94].

\section{BLOCK QUOTE ENDS}

The wound referred to in Anthony Bacon's letter may have been the cause of the lameness Oxford refers to as Shakespeare in the Sonnets: "Speak of my lameness, and I straight will helt" and "I, decrepit . . . made lame by fortune's dearest spite," yet, having the "comfort" of the young man's "Worth and truth . . . So then I am not lame." In the line, "Speak of my lameness and I straight will halt" is likely another play on the word "will" both as future tense and as 'Will' Shakespeare.

The feud between Thomas Knyvet and Lord Oxford would escalate into a full-scale blood feud between the two families much like the one we see in the play between the Montagues and the Capulets. Writing of the feud in 1919, Albert Feuillerat would write that the feud was analogous to the one fought in Verona between the two famous Shakespearean clans: "This was the signal for war between the two houses. As at another time in Verona, the streets of London were filled with the quarrelling clamors of these new Montagues and Capulets [95]." Writing of the ongoing feud between the two rival clans, chronicler Roger Townsend records how he went to Blackfriars Theatre to gain more intelligence on what Oxford's company had planned:

\section{BLOCK QUOTE BEGIN}

And thereupon we went presently down the stairs to go to the Blackfriars ... And so went to the Blackfriars, where Mr. Knyvet, going between us, was set upon. But who they were that did it I know not, for I was so far behind as could not discern what they were [96].

\section{BLOCK QUOTE ENDS}

This links the Earl of Oxford with Blackfriars Theatre, where many of the Shakespeare plays were staged. Indeed, Oxford's men, who participated in the fray, may well have been his theater company players. There were several witnesses present at the time of the incident, which has been recorded by one of the bystanders. The story goes that some of the Thames watermen were on hand. They not only stayed for the entertainment, but even joined the fight, arming themselves with pikestaffs. As one chronicler wrote: 


\section{BLOCK QUOTE BEGIN}

And shortly after, Mr. Knyvet came and then the fray began. And he (the witness) seeing that they were but two of my Lord's men, and many men on the other side, he went in amongst them to keep the peace. He saw besides, 3 with staves, besides watermen with their hooks and staves. One seeming to speak for all the men, he did help to rescue them, being then in some danger as he thought [97].

\section{BLOCK QUOTE ENDS}

The junior master of Caverley's fencingschool, which shared Blackfriars with the theater saw Oxford's men Gastrell and Hosleye there. He recounts: "And seeing swords drawn, and having only about him a single sword, he went amongst them-only to keep the peace [98]."

The next confrontation was more serious. What we know of it comes from a secretary's notation in the margin of a letter of Christopher Hatton's of July 27, 1582, where he recounted, "Mr. Knyvet had slain a man of the Earl of Oxford in a fight [99]." A coroner's jury had returned a verdict of se defendo. On February 21, 1583, a burial register of a church in Bishopsgate would list Robert Brenings, another of Oxford's men, as having fallen in battle, probably at the hands of Knyvet's men. Oxford's man, Gastrell, would shortly after avenge the killing at Blackfriars. He killed one of Knyvet's men called Long Tom. This is revealed in a letter from Lord Burghley to Christopher Hatton of March 12, 1583. In the letter, Lord Burghley makes a moving appeal in defense of Lord Oxford, attempting to defend his honor.

It is easy to see how a blood feud mounted over love as dramatic as this would provide the morbid inspiration for the masterpiece Romeo and Juliet, in which Oxford inspires the composite characters, Romeo and Mercutio as Oxford and company against rival Tybalt, embodied in the flesh as Thomas Knyvet. The fact that Knyvet is recorded as the aggressor in many of these confrontations makes clear that Oxford was not a willing party and tried as best he could to avoid the altercations. He seems repeatedly to have been set upon by Knyvet and his men. Forced to defend his honor and his life, the reluctant Romeo that Oxford was forced into becoming would have made him feel, like his literary counterpart, "fortune's fool." In the play, we see Romeo being forced to slay Tybalt, who refuses to take no for an answer in confronting and challenging Oxford to a duel.

\section{Dating the Play}

As for when The Tragedy of Romeo and Juliet is set, we have the evidence of the Nurse's remark that, "Tis since the earthquake not 11 years." This likely refers to the earthquake that struck the neighborhood of Verona in 1570, since events in England have their geographical parallel in Italy due to the legendary love affair that inspired the play, placing the date of these events in England in 1581. The play therefore seems to be a record of what transpired in Oxford's life at a time beginning in 1581 [100].

\section{What's in a Name?}

Clues to the Tudor princes' authorship of the plays are offered throughout the body of the Shakespeare works. Wordplay was irresistible to the sophisticates of Elizabeth's Court, who delighted in ciphers and games of verbal wit. Ciphers and wordplay were not in vogue simply because it was the fashion. They were indulged in due to political and social necessity. Political intrigues were being launched from all sides and all comers had to veil themselves, their identities and their plans in ciphers and codes. Such inventions are usually mothered by necessity. England was a heavily fortified police state at this time. It is something of a paradox that the flowering of learning in the English Renaissance should happen to coincide with a period of great social and political oppression. Dangers to the throne and the country foreign and domestic were omnipresent. Nobleman had to be ever vigilant in defending themselves against any and all perceived threats.

Character names often reveal a lot about hidden identities that remain in the background somewhere in the shadows offstage. The name 'Romeo' is rich in subtle nuances that some believe make indirect reference to the Earl of Oxford. The sounding of the name echoes with the initials E.O. at the end, which of course designate the Earl of Oxford. The word 'roe' signifies a species of deer, which tease greater meaning out of the lines, "Here comes Romeo, here comes Romeo/Without his roe, like a dried herring [101]." 'Romeo' without the 'roe' is meo or Me, O. In other words, Me, Oxford. Such wordplay was standard fare in Elizabethan England, where messages, dispatches, and communiques had to be transmitted frequently between parties anonymously so that the identity of the bearer of that news would be protected. Now that we understand this, we can see how Juliet's lines in the balcony scene take on new meaning:

\section{BLOCK QUOTE BEGIN}

What's in a name? That which is called a rose By any other name would smell as sweet.

So Romeo would, were he not Romeo called, Retain that dear perfection which he owes Without the title.

(Romeo and Juliet, 2.2. 891-894)

\section{BLOCK QUOTE ENDS}

The significance of these lines is of course that it alludes to the red rose of the Tudor family in the disguise of something of universally acknowledged beauty. In essence, what the playwrights-since the play appears to be a joint effort of the Tudor princes, Edward de Vere and younger brother Francis Bacon- 
are doing is revealing their identity as the Tudor princes hidden behind the visor of Pallas Athena's helmet of invisibility. Though they can't bear "the name of the rose," they still smell as sweet since they bear the royal bloodline of the Tudor family and retain the "perfection" that they own as royal princes, while being unable to bear the actual title "prince" during the reign of Elizabeth, their mother. Sir Francis Bacon takes credit for the play in his embedded cipher history, claiming that the play was inspired by his love affair with Marguerite de Navarre. While this may be factual, Romeo and Juliet are at the very least composite characters. If the Veronese lovers represent a youthful Bacon and Marguerite, they just as certainly represent the besotted Oxford and the Queen's handmaiden, Anne Vavasor.

There is a high probability that Queen Elizabeth is represented in The Tragedy of Romeo and Juliet as the fair Rosaline, the name meaning "line of the Rose" or "Tudor line." Rosaline never appears in the play, which should be revealing in itself, but is only alluded to in lines of dialogue in the opening scenes. All we are told is that Romeo is "in love but out of favour" with her. In what Romeo says of her, it is clear the Bard is alluding to the Queen:

\section{BLOCK QUOTE BEGIN}

She hath Dian's wit,

And, in strong proof of chastity well arm'd,

From loves weak childish bow she lives unharm'd.

(Romeo and Juliet, 1.1.238-240)

He later expands on his description by adding:

Ope her lap to saint-seducing gold,

$\mathrm{O}$, she is rich in beauty; only proof

That when she dies, with beauty dies her store.

(Romeo and Juliet, 1.1.243-245)

\section{BLOCK QUOTE ENDS}

The fact is that Elizabeth had been courted by several nobles, even on one occasion, a member of the French royal court, who lavished gifts upon her in order to win her favor. Despite being secretly married to her consort Leicester, she was tempted as any spoiled child tends to be, but in the end resolved to resist the union, Lord Burghley advising her to buy off the jilted suitor with a large financial payoff. Instead, Elizabeth said, as Romeo testifies of the fair Rosleine, "she hath sworn that she will still live chaste [102]." The true import of this is that Queen Elizabeth will "live" as though chaste, as opposed to actually being so:

\section{BLOCK QUOTE BEGIN}

... and in that spring makes huge waste;

For beauty, starv'd with her severity,

Cuts beauty off from all posterity,

She is too fair, too wise, wisely too fair,

To merit bliss by making me despair.

She has forsworn to love, and in that vow

Do I live dead that live to tell it now.
(Romeo and Juliet, 1.1.247-253)

\section{BLOCK QUOTE ENDS}

Once having made the Queen think she is found in these sweet compliments, where she finds herself in the character Rosaline, the Tudor princes later take back the compliment by surreptitiously taking a jab at her in a far subtler passage. Romeo's words to Juliet in the balcony scene are given in an aside and are as much addressed to the Queen as to Anne Vavasor in the guise of Juliet:

\section{BLOCK QUOTE BEGIN}

But, soft, what light from yonder window breaks?

It is the east and Juliet is the sun!

Arise, fair sun, and kill the envious Moon,

Who is already sick and pale with grief,

That thou her maid art far more fair than she,

Be not her maid, since she is envious,

Her vestal livery is sich and green,

And none but fools do where it; cast it off.

(Romeo and Juliet, 2.2.846-854)

\section{BLOCK QUOTE ENDS}

Queen Elizabeth I was identified with the Moon as her occulted personage, probably because she was forced to play the part of the chaste Queen due to her inability to find an acceptable marriage partner. This was due to the strict stipulations enforced by her father's will and testament, which required that any candidate who hoped to win her hand in marriage had to meet with the approval of the Privy Council. Henry VIII was apparently motivated to make this proclamation in his will and testament on account of the intrigues on the Continent and the high likelihood that suitors would come in the form of spies, agents and even usurpers of foreign courts, and that his daughter's judgment alone could not be trusted to vet such candidates for the throne.

It is plain that one or both of the Tudor princes is reproving the Queen in this insulting soliloquy, exacting revenge for the humiliation she has subjected Oxford and his lover to as a result of their confinement in the Tower of London. It is obvious that the "envious Moon" is the Queen, who is jealous that her fair young maidservant has eclipsed her beauty. Indeed, in the passage described, the Moon, a personification of the Queen, has been eclipsed by the Sun, whose radiance and bedazzling light far exceeds the pale Moon itself. Romeo then makes two references to Juliet as the maid of the Sun, which is exactly the role of the Queen's maid of honor, Anne Vavasor. He then entreats the maidservant of the "Moon" to discard her "vestal livery." A vestal was worn by all maidservants of the Queen, but this one is described as "sick and green," which implies that the loyalty and fealty of the Queen's servants is wanting. It also implies that the Queen is green with jealousy and that her maidservant owes her no loyalty whatsoever. To accuse the vestal Moon of 
envy was a malicious attack on Elizabeth's vanity, as she was notorious for trying to monopolize the affections of all the courtiers around her, resenting them should they ever fail in making her the object of their undivided attention. The affront is unmistakable, and had it been made by any other courtier, would have been considered treasonous and seditious and would most likely have cost him his head. The Tudor princes gets away with it for two reasons: they are the Queen's illegitimate sons and cannot be blamed, since censoring either of them would be tantamount to exposing the identity of Shakespeare, which could not be allowed, as it was a state secret and a matter of national security. If his cover were to be blown, the whole covert operation would be exposed, Shakespeare himself revealed for the actual Bard that he was, and the jig would be up. It would then become plain who the political targets of the plays actually were. In short, the transparency would have been too much, rendering bare not just the empress who had no clothes, but her entire Court, not to mention the court officials of Europe who were also being lampooned and made into figures of fun in the plays.

The insult to the Queen extends further into the balcony scene. At one point, when Romeo declares his love for Juliet by swearing by the Moon, Juliet says, "O, swear not by the Moon, the inconstant Moon/That monthly changes her circle orb . . . " (Romeo and Juliet, 2.2.958-959) This is a thinly veiled attack against Her Royal Majesty, who was known for her inconstancy in love, and for changing lovers by the month, pretty much playing the field among the courtiers with her lustful appetite, which was driven to seduce the men of court, one by one. Indeed, a monarch identified with the goddess of the Moon hardly makes the Moon the right heavenly body to swear by, when quite unlike the Moon goddess, the inconstant Queen is far from chaste. The only reason the Queen was ever compared to the chaste Moon goddess-Diana/Cythia/Virginia-was because she was unwed and falsely represented as being without "issue," meaning without a child to succeed her, which we now know to be untrue.

The courtier playwright is of course skillful and clever enough to conceal his attack in indirect allusion, abstract metaphor, and symbolism. Having identified the Queen with the "fair Rosaline," who is referred to at the beginning of the play, the Queen can hardly turn around and say, "Did you hear that? I am meant to be Rosaline. He is having a go at me. He is alluding to me when Romeo bids the sun to kill the envious Moon. I am the Moon he wishes to see dead." For the Queen to speak out and declare her outrage would only make her look the more ridiculous. One can almost see the Tudor princes smiling offstage as Romeo's lines deliver the appropriate sting, knowing full well that they will be utterly immune to prosecution even though they have just insulted the person holding the highest office in the land. Herein lies the beauty of the metaphoric pen name "Shakespeare," under whose guise the Tudor princes published plays containing veiled attacks upon the most powerful nobles of the Court. Most nobleman are aware who Shakespeare is, but his enemies dare not speak his real name, for if they did, they would be exposing themselves through association, since he had maligned many of them covertly in his plays. And for the Queen or any of her courtiers to prosecute the courtier-playwright for libel would be equally damaging to all concerned, for the exposure of one attack would leave them all compromised, initiating a crisis in the Elizabethan Court of unparalleled dimensions. Not even the Queen could afford to expose the playwright through any form of censure or disapproval.

\section{Anne Cecil as Desdemona, Ophelia and Other Shakespearean Heroines}

Not long into his ill-fated arranged marriage to Anne Cecil, Lord Burghley's daughter, a crisis erupted that would leave Oxford estranged from his wife for a period of five years. The cause of the estrangement appears to be Oxford's unwarranted and unfair suspicion of his wife's infidelity and his certain conviction that the child she bore him was not his. Oxford turned over to his wife the house at Wivenhoe and their lodgings in the Savoy and withdrew to separate lodgings for a period of some five years. According to Lord Burghley, Oxford wished to make the sons of his uncles, his dear cousins, Francis and Horatio Vere, his heirs. It is plain therefore that he did not acknowledge Anne's child as his proper heir. The first clue to this historical anomaly comes from the letter written by Dr. Richard Masters, one of the Queen's physicians, to Lord Burghley on March 7, 1575, two months after Oxford had left the Court for Europe. The letter is presented below:

\section{BLOCK QUOTE BEGINS}

To the Right Honourable Lord Burghley, the Lord Treasurer of England. After my duty it may please your Lordship to understand Her Majesty this Monday morning in the chamber at the gallery and next to the queen sitting alone, I said, 'Seeing it hath pleased your Majesty oftentimes to inquire tenderly after my Lady of Oxford's health, it is now fallen out so (God be thanked) that she is with child evidently; and albeit it were but an indifferent thing for her Majesty to hear of, yet it was more than indifferent for your Lordship to signify the same unto her." Herewith she arose, or rather sprang up from the cushion, and said these words: "Indeed, it is a matter that concerneth my Lord's joy chiefly; yet I protest to God that next to them that have interest in it, there is nobody that can be more joyous of it than I am." Then I went forth and told her that your Lordship had a prior likelihood of it upon your coming from the court to Shrovetide, but you concealed it. 
Her Majesty asked me how the young lady did bear the matter. I answered that she kept it secret four or five days from all persons and that her face was much fallen and thin with little colour, and that when she was counseled to be gladsome and so rejoice, she would cry: "Alas, alas, how would I rejoice seeing he that should rejoice with me is not here; and to say truth stand in doubt whether he pass upon me and it or not"; and bemoaning her case would lament that after so long sickness of body she would enter a new grief and sorrow of mind. At this Her Majesty showed great compassion as your Lordship shall hear hereafter. And repeated my Lord of Oxford's answer to me, which he made openly in the presence of Her Majesty, viz., that if she were with child it was not his. I answered that it was the common answer of lusty courtiers everywhere, so to say... Then she asking and being answered of me was in the next chamber, she called me Lord of Leicester and telleth him all. And here I told her that either to reveal it or to keep it and lose. And here an end was made, taking advantage of my last words, that she would be with you for concealing it so long from her. And severally she showed herself unfeignedly to rejoice, and in great offence with my Lord of Oxford, repeating the same to my Lord of Leicester after he came to her. Thus much rather to show my goodwill than otherwise desiring your Lordship, that there may a note be taken from the day of the first quickening, for thereof somewhat may be known noteworthy. From Richmond the 7th of March, 1575.

By your Lordship's most bounden,

Richard Masters [103]

\section{BLOCK QUOTE ENDS}

Our next fragment of information comes from a diary note Lord Burghley wrote to himself on January 3 , 1576, following the birth of the child, in which he wrote of his sister-in-law that:

\section{BLOCK QUOTE BEGINS}

He confessed to my Lord Howard that he lay not with his wife but at Hampton Court, and that then the child could not be his, because the child was born in July which was not the space of twelve months [104].

\section{BLOCK QUOTE ENDS}

Further information is vague, but it is generally believed that the Court was abuzz with news as to the paternity of the Countess of Oxford's child. As for Oxford, it is quite probable that allegations of infidelity were sown in his ear to work on his good sense like a poison. The Iago-like villain responsible for the malediction was none other than Henry Howard and his accomplice, Rowland Yorke. The trouble began as the result of an indiscretion on Oxford's part. The problem with noble-minded artistic temperaments is that they are generally too pure to be of a suspicious nature, and are too inclined to trust. Acquaintances, whose true mettle has not been tested, are too often brought into the inner sanctum of the artist's court, where he is inclined to lay bare his most carefully laid plans. People of a more malicious disposition will use such confidences against those of a purer nature to undermine their reputations and good standing.

Lord Oxford had actually confided to Lord Howard before leaving for Paris that, if his wife were with child, it could not be his, as he had not lain with her since October. A Catholic and secret supporter of Mary Queen of Scots, Howard was credited with the "evil counsel which brought about his brother's ruin." Sir Francis Bacon's mother by royally appointed adoption, Lady Anne Bacon, called him a "dangerous, intelligencing man, and no doubt a subtle papist inwardly [105]." In warning her son Anthony Baconco-founder with his brother of HMSS - about Howard, she said, "he, pretending courtesy, worketh mischief perilously"-a "subtle serpent." In the words of a French ambassador "he was one of the greatest flatterers and calumniators that ever lived [106]." Of a generous, forthright, and artistic temperament, Oxford was entirely guileless and uncalculating, probably inclining toward thinking the best of everyone. Like Iago, Lord Howard, on the other hand, probably shared his literary counterpart's motiveless malignity. Howard may have had a political motive though for plotting to make Oxford's family dysfunctional. To set Burghley off against his son-in-law would have the added effect of pitting two of the most powerful nobles of the Elizabethan Court against each other. There was probably an element of jealous spite as well, in that Oxford was one of the greatest talents in the land and, in fair weather, the Queen's favorite.

"Receive her into your house," Oxford would tell Lord Burghley, "for there, as your daughter or her mother's, more than my wife, you may take comfort of her [107]." In essence, Oxford had killed his wife with his indifference, murdering her with cold spurning as Othello would murder Desdemona in the play. The poor unfortunate was ill-equipped to deal with "the slings and arrows of outrageous fortune" that attend the life of a literary genius. Having the patience to forebear Oxford his passionate and willful nature - while having the tolerance to endure the crises, political and filial, that would have beset the home of so intransigent a personality - would have been beyond the scope of her limited imagination. Oxford's greatness would have so dwarfed the mediocrity of those around him, rendering them deaf to understanding and mute to displays of support and sympathy. Ophelia is so like the insipid, frail, submissive Anne, as to be a mirrored reflection. Both were too weak for the overwhelming passion of the dark brooding Hamlet figure in their lives, whose imagination and philosophical speculations were so profound as to inflict violence upon lesser spirits. Ophelia's fragile intellect, like Anne's delicate mental and physical health, would have been shattered like fine crystal by the high-pitched passions of Oxford, much like Cathy being overwhelmed by Heathcliff's 
overbearing nature in Wuthering Heights. These delicate feminine natures are prone to hysteria and are driven by a Cassandra-like complex, while the overbearing male natures are dark, brooding, paranoid, jealous and spitefully vengeful by nature.

Oxford's marriage to Anne Cecil can be likened to Angelo's marriage to Mariana in Measure for Measure. The name 'Mariana' may be taken as a contraction of 'Marry Anne' or 'Marry Anna.' Angelo is husband by pre-contract or arranged marriage to Mariana. Of the contract Angelo says:

\section{BLOCK QUOTE BEGINS}

... was broke off,

Partly for that her promised proportions

Came short of composition, but in chief

For that her reputation was disvalued

In levity; since which time of five years

I never spake with her ...

(Measure for Measure, 5.1)

\section{BLOCK QUOTE ENDS}

Oxford, it is well known, was estranged from his wife for precisely five years which would seem to make this a piece of autobiographical writing and no coincidence or accident. Angelo says he broke off the marriage to Mariana because "her reputation had been disvalued in levity" just as Anne would fall victim to vicious rumors. In the play, we seem to be hearing either a confession from Oxford or an apology on his behalf by half-brother observer Bacon for Oxford abandoning his bride under the pretext of infidelity. It is the Duke who reveals the depth of Angelo's betrayal of his bride, when he speaks of Angelo's abandonment of Mariana:

\section{BLOCK QUOTE BEGINS}

Left her in tears and dried not one of them with his comfort, swallowed his whole, pretending in her discoveries of dishonour; in few bestowed her on her own lamentation, which she yet wears for his sake; and he a marble to her tears, is washed with them but relents not.

(Measure for Measure, 5.1)

\section{BLOCK QUOTE ENDS}

Either Oxford is subjecting himself to selfrecrimination through his plays or his half-brother Bacon is functioning as his apologist, especially with regard to Oxford's neglect of Anne in play after play. Measure for Measure, therefore, appears to be a confession or apology that the excuse Oxford had devised for deserting his wife. What is historically most likely is that Oxford was so anxious to get out of an unhappy marriage and out from under the yoke of an overly domineering father-in-law-by overdramatizing the allegation of infidelity-granting himself the quickest and most legitimate-sounding excuse in the process.
The dramatist, like any artist, represents his life to a greater or lesser extent through his work, the more successfully, the more enduring the artifice will be: the more closely it represents nature, the more interminable will be the reflection of mirrors within mirrors, echoing like a cacophony of sounds into the endless expanse of history. In short, the Tudor princes would craft Oxford into Othello, as Anne Cecil would be transformed into Desdemona, while Lord Burghley becomes Brabantio, Desdemona's father, "In his effect a voice potential/As double as the Duke." The villain of his life's drama, Rowland Yorke, with Henry Howard added to him, would become Oxford's deceiver in the personage of Iago, which is almost a transliteration of Y-orke. Oxford's sacrifice of Anne upon the rumors of her infidelity, would be given artistic expression in the undoing of Desdemona by the demon of Iago, who seized a hold of virtuous Othello, laying siege to his psyche, overwhelming the battlements of his mind and perverting him into doing evil. The device of the handkerchief was a deft touch, sleight of hand, a magician's conjuring, a magic trick. Magic can only work on an audience if they want to be deceived and tricked. The audience wants the magic trick to work and eggs the conjurer on to be the master trickster. They want to be tricked and have their senses deceived, and that is where the excitement and titillation originates. And like the conjurer's audience that willingly allows itself to be duped, Oxford wanted to be deceived and wished to think ill of his wife, as it provided him with the excuse he needed to leave her. Othello allows his ear to be bent to Iago's evil purpose because, ultimately, he wants to be deceived. Othello is driven by a kind of death wish to undermine his own happiness by throwing himself headlong into tragedy because his excessive nature despises the mediocrity of too much contentment and happiness. It is as if he is asking the same question as Nietzsche, "What good is my happiness? It is poverty, dirt and a miserable ease [108]." Othello attends Iago's words too closely not to be affected by them. He is like the audience that tries not to see what is under the handkerchief because they want the illusionist's magic to work on them. Iago anticipates Othello as a spider might attend upon its quarry in the web of its own design. Iago's mouth requires a receptive ear. He desires Othello to have a tragic fall and Othello is all too willing to trip.

Oxford would lament the fact that he had been the cause of so much pain on the part of his wife. In The Winter's Tale, Oxford seems to be implied by the character Leontes, who feels remorse for being the cause of his wife and son's death, when he mourns how, "Once a day I'll visit/The chapel where they lie, and tears shed there/Shall be my recreation." Oxford's wife Anne died young at age 32, while his only legitimate son would live only a few days. Either Oxford is blaming himself for the lamentable condition of his wife and child, laying the blame at his doorstep, or halfbrother, Francis Bacon, is acting as his apologist in play 
after play. In any event, Oxford appears to expiate his guilt and do penance for his sins through the Shakespeare plays. One can almost hear the ghost of Oxford's wife reproving him from beyond the grave when Pauline-upon Hermione's apparent deathupbraids Leontes in The Winter's Tale:

\section{BLOCK QUOTE BEGINS}

\section{O thou tyrant!}

Do not repent these things: for they are heavier

Than all thy worse can stir. Therefore betake thee

To nothing but despair..

(The Winter's Tale, 3.2.224-227)

\section{BLOCK QUOTE ENDS}

Leontes is not the least loath to countenancing these recriminations, pleading instead that the knife of accusation might be plunged deeper so as to accomplish its full work: "Go on, go on,/Thou canst speak too much. I have deserv'd/All tongues to talk the bitterest." (The Winter's Tale, 3.2.233-234) But Othello may be the most lamentable in history for outdoing all the rest in terms of self-loathing, outdoing even the most lamentable figure in classical literature, Oedipus, who committed the two most cardinal of sins by committing patricide and incest.

\section{Oxford's Changeling Bride}

Lord Burghley, desperate to preserve the marriage between Oxford and his daughter, was always hatching schemes to tighten the bond. One can imagine that the divorced wife of an earl would have no chance of remarrying with another suiter of noble rank. She would be considered a fallen woman, even if the rumors about her were untrue. Burghley seems to have been motivated to preserve the marriage so that he could have an heir. He would want to ensure the status of his descendants as Earls of Oxford. Three years after the wedding, the couple had still not produced a child. Oxford was planning a trip to the Continent from which he might not return. Burghley may well have been driven to desperate measures to bring Oxford to bed with Anne. Anne did have a child christened Elizabeth Vere in fact. The question is why did the father reject the child as his, only to come around later to embrace the child, just as Leontes eventually came to accept Perdita, the Lost One, as his own? What could possibly account for this strange event? J.T. Looney provides the answer. While reading The Histories of Essex (1836), by Morant and Wright, he found a revelatory passage that must have astonished him in terms of its implications. It became apparent that Oxford had been duped by a clever plot, the passage claiming, that:

\section{BLOCK QUOTE BEGINS}

He forsook his lady's bed, (but) the father of Lady Anne by stratagem, contrived that her husband should unknowingly sleep with her, believing her to be another woman, and she bore a son to him in consequence of this meeting [109].

\section{BLOCK QUOTE ENDS}

Once again, the apparent biographical details of Oxford's life seem to relate perfectly to the events in many of the plays. In All's Well that Ends Well, for instance, Bertram is brought to father a son by precisely the same strategy. In fact, the BBC in its 1980 production of All's Well That Ends Well, cited the report about Oxford in The Histories of Essex in the program, which as it happens was shot at Burghley House, presumably because the production team recognized the Lord Treasurer in the character Lafue. What other historical figure besides the Earl of Oxford would have both the intimate knowledge of and motive for lampooning Burghley through dramatic works? The fact that Burghley is captured in the character of Polonius and Lafue suggests that the Tudor princes were on to him and had at him through the plays.

In 1943, Charles W. Barrel uncovered another somewhat different account of the story from a source with a direct connection to the de Vere family. Francis Osborne was master of Horse, Herbert, Earl of Montgomery, who was married to Oxford's youngest daughter. In his historical volume, Traditional Memoirs of the Reigns of Elizabeth and James I, he related the details of how Oxford was deceived into sleeping with his wife, the writer insulting the earl's honor by the claim that he had:

\section{BLOCK QUOTE BEGINS}

Nothing to testify for his manhood but a beard and children, by the daughter of the last Earl of Oxford, whose lady was brought to his bed under the notion of his mistress and from such a virtuous deceit (the Countess of Montgomery) is said to proceed [110].

\section{BLOCK QUOTE ENDS}

Oxford could easily have been taken advantage of in this way for anyone aware of his weakness for drink. Knowing that his son-in-law was no teetotaler, Burghley may have seen a chance to take advantage of Oxford's weakness. Knowing his son-in-law's character and of what actions he was capable, Burghley may have known how easily duped Oxford could be when under the influence. One wonders whether the ploy was successful. If we combine the historical accounts with their fictional counterparts found in the comedies, it would seem that the scheme was not only enacted, but probably laid the foundation for what became known as the bedroom farce. Even A Midsummer Night's Dream carries the theme, with the players Hermia and Helena, Lysander and Demetrius, finding themselves thrown together in mismatched unions due to the influence of a powerful chemical, not alcohol in this instance, but the pollen from a particularly potent flower, while nevertheless the effect is the same. The characters have no control over their senses or judgment, becoming so muddled in the head that they feel love-besotted towards those they would have felt no allure or attraction to had they been sober. This is the effect 
stimulants and hallucinogens have on the human brain, with elevated dopamine levels producing sensory confusion, increased endorphins producing heightened states of pleasure, and a stimulated amygdala resulting in diminished impulse control. Taken together, these factors are a potent cocktail in their own right, producing the so-called "happy drunk" who loves everyone and is likely to find himself in bed with virtually anyone.

In All's Well That Ends Well, as in the story of Boccachio, which provides the literary parallel, the young ladies are switched to bring Bertram to bed with his proper mate to produce a legitimate son and heir, the same motive that inspired Burghley to orchestrate the ruse on his son-in-law, Oxford. This effected an eventual reconciliation between the young Count and the long-suffering Helena. The same deception is employed in Measure for Measure to compel Angelo to consummate his marriage-by-pre-contract to Mariana or "Marry Anne."

\section{Stout-hearted Oxford}

It makes sense that artists of extraordinary talent would have lives as remarkable as their work. This premise holds true with the lives of most artists of great renown, including Hugo, Dickens, Shelley, Byron, Blake, etc. And it is equally true of the Tudor princes, Oxford and Bacon. While Baconians will insist that Bacon is the sole author, an objective Shakespeare scholar will admit that there are different styles among the plays and that they did not all issue from one pen. It appears most likely that it was a collaborative effort, and that the far more dramatic and dynamic Bohemian life of the Earl of Oxford, provided fodder and inspiration for many of the plays. Whether the Tudor princes collaborated or whether, as Baconians contend, the Shakespeare plays were the product of Bacon's writing quill, it is undeniable that there was a collaboration of some sort, since as the Lord Chamberlain, the Earl of Oxford's company of players did perform many of the Shakespeare plays for the Court. Even if Bacon was the primary or sole author of the plays, his half-brother and fellow Tudor prince, the Earl of Oxford, certainly seems to have influenced the plots, themes and characters of many of the plays, which appear to be drawn directly from the tapestry of his extraordinary life.

It is almost a given that the great-souled artist will live as dramatic a life as the characters featured in his works. And there is no denying that the earl was given to exactly this kind of romantic adventuring throughout his life. In addition to his participation in several military campaigns, for instance, Oxford is known to have taken part in the naval battle against the Spanish Armada. The man from Stratford had so seemingly humdrum a life in contrast, one can scarcely imagine where he would have acquired the worldly knowledge and experience to provide fodder for the enormously colorful pageantry found in the plays.

Philip II's so-called Invincible Armada was scheduled to sail in 1587, but Sir Francis Drake upset these plans by what is referred to as the "singeing of the King of Spain's beard." Dashing into the Bay of Cádiz in a reconnaissance and subterfuge mission in April, Drake destroyed 30 ships and made off with a pirate's booty in treasure, stormed a castle guarding the Port of Lisbon-which he blockaded a month before launching an attack on a carrack in the Azores - in another act of piracy on the high seas. These victories at sea would grant his country a reprieve of one year, successfully staving off the launch of the Armada by wielding a heavy blow to Spanish morale and confidence. In the meantime, the competent sea admiral Santa Cruz died in the interim. His replacement, the Duke of Medina Sidonia, had no naval experience outside the Mediterranean, and was so lacking in confidence that he would only assume the command under direct orders of the king. The fleet assembled at Lisbon on May 20, 1588 with 132 ships and nearly 30,000 men, as formidable as any fleet that ever set sail. Its mission was to sweep the English Channel of all opposition in order to permit the Italian nobleman, Alexander Farnese, the Duke of Parma, to cross with an army to subdue the English. Less than half the fleet consisted of fighting ships and the number of competent seamen was only 8,000 , the rest being soldiers intended for boarding. The English responded to the Spanish threat by gathering a force of 197 vessels, the vast majority being merely privately owned and very small. In a sense, this gave the English the advantage, since their ships were fairly agile and quite maneuverable. The English navy boasted only 34 that could be called the Queen's own. These, however, embodied the sleek new designs that Sir John Hawkins, Drake's cousin, had been working on for a quarter of a century. Lower galleys and deeper keels increased their speed and seaworthiness. Their heavier long-range guns could batter the enemy from a distance and frustrate their boarding capabilities. The vast majority of the English crews numbering 16,000 were seasoned seamen.

On June 10, 1588, the Armada was broadsided by a storm off the northwest cape of Spain. The entire fleet had to put into port for repairs. It did not set out of port again until July 12 of the same year, giving the enemy substantial time to muster its forces and prepare its battle strategies. The Armada was sighted off the Lizard, the notorious southern cape of England's western tip at Cornwall. Drake was playing at bowls at the time and insisted on finishing his game before putting to sea with Admiral Howard and fellow captains, Hawkins and Frobisher. An eyewitness account presents a quite impressive scene: 


\section{BLOCK QUOTE BEGINS}

The 19th of July, the English Admiral . . . sends a special summons unto all the English fleet . . . The Queen forthwith commands more ships to the sea, whereupon, yet in voluntary manner, the Earls of Oxford, Northumberland and Cumberland. Sir Thomas Cecil, Sir Robert Cecil, Sir Walter Raleigh . . . and many honorable personages, were suddenly embarked, committing themselves unto the present chance of war [111].

\section{BLOCK QUOTE ENDS}

At 2:00 AM on July 20, the main English fleet set upon the Spanish from the rear. The Spanish ships were outmaneuvered and outclassed at every turn. The Spanish were thwarted in their every effort to board the English vessels. Among the ships they lost in the early battles was the flagship of the squadron of Andalucia, Nuestra Senora del Rosario. The truth of the matter is that the British commandeered the ship and had it sail under its own colors-renamed HMS Rosario - in a maneuver not unlike an interception in American football. A commentator offered more details of the principles in the battle, keeping a log for July 26, 1588:

\section{BLOCK QUOTE BEGINS}

So far was the title of invincible or their terrible aspect unable to affright our English shores; that the youth of England . . . with ships hired at their own charges, joined themselves in great numbers with the fleet (before Calais), with generous alacrity, and incredible courage; and amongst others, the Earls of Oxford, Northumberland ... [112].

\section{BLOCK QUOTE ENDS}

More is said of the Admiral and of Oxford in a verse written to commemorate the battle. The poem describing the battle published under the name I.L. the following year was probably written by John Lily, one of Bacon's masks, employing the name of one of his secretaries, Ihon Lillie how he often signed himself under this moniker. The poem is significant not just for the valor it attributes to Oxford, but for the inspiration he derives from Pallas Athena the Spear-shaker, whom the poem refers to as his inspiration and guardian goddess, the muse to which he owes his poetic career is also depicted quite exceptionally as inspiring his military exploits:

\section{BLOCK QUOTE BEGINS}

The admiral with Lion on his crest, Like to Alcides on the strand of Troy,

Armed at assay to battle is addressed;

The sea that saw his powers waxt calm and coy, As when that Neptune with three-forked mace For Torjans' sake did keep the winds in chase. De Vere whose fame and loyalty hath pierced The Tuscan clime, and through the Belgike lands By winged Fame for valour is rehearsed,

Like warlike Mars upon the hatches stands,
His tusked Boar 'gan foam for inward ire, While Pallas filled his breast with warlike fire [113].

\section{BLOCK QUOTE ENDS}

On July 27, 1588, as we learn from the Earl of Leicester's account of events, Oxford left the fleet and came to Tilbury, a village on the Thames, halfway to London from the sea. No reason is given. One can only imagine that Oxford was esteemed rather more highly for his land battle capability and was summoned to Tilbury to rally the forces for the anticipated assault of Farnese's Spanish army, whose landing was anticipated.

The Spanish were so soundly defeated in the coming fray, that blood could be seen trailing from their ships' scuppers after being pummeled by the English guns. The Armada took shelter in Calais that same evening. It would be a fatal mistake for the Armada, fortune having turned against the hitherto invincible Spanish navy. A detachment of the English fleet, consisting of 35 ships - which had been bolstering the Dutch navy's blockade of Farnese's Spanish armynow joined the main English force. On the evening of July 28, Admiral Howard made up his mind to attack. At midnight, eight 150-ton vessels loaded with explosives were set ablaze and sent among the eerie hulks of the Spanish vessels, which would have resembled ghost ships in the amber light of the blazing fires. The Spanish ships began sending a shower of timbers everywhere, creating a wave of panic that would drive many vessels out to sea. In the mad frenzy, many ships collided with one another, while some weighed anchor to embark in a more orderly fashion. One of the largest of the galleys even ran aground.

Admiral Medina attempted an anticipated rendezvous with Farnese's transports, but it was no use. The absence of an auspicious tide had confined these ships to their berths. And then without warning, a reinforced English fleet appeared out of nowhere. For eight hours, the sea battle raged with ships pummeling each other at close quarters off Gravelines, the English endeavoring to pin their foes against the sandbanks, the Spanish struggling to get to sea. A hard northwesterly threatened to send the entire fleet to its doom on the lee shore, but by the morning of July 30, the wind abated and the Spanish were able to reach deeper water. By now, however, morale was so low following the drubbing they had suffered, their confidence so beleaguered by the swifter and superior English ships, that retreat was the only option left to the Spanish admiral, whose confidence had been shattered. On the English side, frustration set in at the fact that their artillery had been spent, permitting the Spanish the opportunity of escape, which might otherwise not have been open to them. The report sent home to England was that "Howard in fight spoiled a great number of the Spaniards, sank three and drove four or five on the banks [114]." The admiral himself wrote of the 
occasion, "Their force is wonderful great and strong, yet we pluck their feathers by little and little [115]."

The powerful Armada was still largely intact despite defeats. The English had no way of knowing that the Spanish had already given up the fight. On August 8, Queen Elizabeth went to inspect the army gathered at Tilbury, expectant of an invasion by Farnese's troops. The Queen must have made an impressive sight as she arrived on the field to inspect her troops:

\section{BLOCK QUOTE BEGINS}

Mounted on a noble charger, with a general's truncheon in her hand; a corselet of polished steel laced over her magnificent apparel; and a page in attendance bearing her white-plumed helmet; she rode bareheaded from rank to rank with a courageous deportment and smiling countenance ... amid the affectionate plaudits and shouts of military ardor which burst from the animated and admiring soldiery ... [116].

\section{BLOCK QUOTE ENDS}

Her dauntless address to her troops, which was written down and read to them by their officers, was indisputably Shakespearean in tone, and as Oxford had left the fleet to alight at Tilbury, it may be that he had written the Queen's address for her. Indeed, the unusual expression "foul scorn" occurs in both the address and in Shakespeare's work, while "hearts and goodwill" appear in the Queen's address as well as the works of Shakespeare.

The Spanish chose not to retrace their wakes back down the English Channel to face the wrath of the English navy. Instead, they turned north through turbulent seas, making a passage past the coast of Norway. Beating a course homeward, they were forced to make for the Irish coast due to lack of water, where autumnal winds of unprecedented force destroyed 19 of their vessels. Crews that put ashore and fell into the hands of the English officers were massacred. A total of 8,000 failed to escape. Indeed, it could be said that the Spanish were assailed not just by the English Navy but by the elements as well. It was like the entire realm of the British Isles had summoned up its fury to drive the Spanish off. There is evidence that Sir John Dee, who was practiced in sorcery, had something to do with it. Those with an open mind would do well to consider this claim. There are even suggestions he employed weather warfare by using various occult practices, including geometrically designed metallic constructions placed at designated points throughout the British Isles. To the close-minded this might seem absurd, but similar strategies were employed in World War II under Winston Churchill, who summoned Druidic covens from all over the country to perform rituals, believed to be responsible for such weather anomalies as banks of fog, which obscured the Luftwaffe's targets.
In the end, half the Spanish fleet managed to limp back to port in Iberia, Spain under the helm of the starving and malnourished sailors, while two-thirds of the crew were lost at sea. The English sea captains on the other hand had not lost so much as one ship, and even then showed some dissatisfaction with the results of the battle. Even the English Catholics rallied around their Protestant Queen in one of the greatest displays of solidarity in English history [117].

\section{Shakespeare the Sailor}

Careful study reveals that the Shakespeare plays were not the work of one individual, despite the claims of Stratfordians, Oxfordians and Baconians to the contrary. The plays themselves present stylistic characteristics that suggest that contributions were made by at least four distinct contributors. One thing is certain, whoever penned these masterpieces was privy to advanced knowledge in a host of fields. Francis Bacon's Team of Good Pens - the secret writing guild known as the Honourable Order of the Knights of the Helmet - was 70 strong. That's a lot of manpower. In addition to the expert knowledge displayed in the fields already discussed, the author(s) also display advanced knowledge of navigation and seafaring terminology, as the following lines from Sonnet 116 reveal: "It is the star to every wandering bark,/Whose worth's unknown, although the height be ta'en." (Sonnet 116) This is an obvious reference to the Pole Star to anyone with even a rudimentary knowledge of navigation. The Pole Star allows the navigator to determine his latitude as well as directional heading. While many Elizabethan English were familiar with the art of navigation, to employ seafaring terminology learnedly would require an education in seamanship for the correct meaning and use of terms used for the proper manning of ships. The author of the Shakespeare works expresses such familiarity with seafaring terminology that he comfortably employs them in metaphors as in the following turn of phrase from King John: "And like a shifted wind unto a sail,/It makes the course of my thoughts to fetch about." This is an obvious reference to the practice of tacking, which consists of bringing a ship's head around to lie in the opposite direction. "To fetch about" has the same meaning as "to tack." As for the word "course," it not only refers to the heading of the ship, but also to the principle sail of a square-rigged ship [118].

\section{The Origins of Shylock}

In 1576, Sir Humphrey Gilbert, the soldiernavigator responsible for the early colonization of North America, had his eyes set on the Orient as well. He published a tract called A Discourse of a Discoverie for a New Passage to Cataia. It alleged that the new passage westward was the only way to lay hold of the riches of the Orient that awaited eager hands. There were other notable enthusiasts signed up for the search for the Northwest Passage: soldier-sailor Martin Frobisher; Michael Lok, a London merchant with a 
Mediterranean business, whom de Vere may have met originally in Venice or Genoa; Richard Hakluyt, a geographer at Oxford University; and a dear old friend of both Tudor princes, Edward de Vere and Francis Bacon, and the incomparable court astrologer, seer and occultist, Sir John Dee, who also operated under the pseudonym Mercator, who was advanced as a great cartographer, but whose countenance matched Dee's own, and proved to be one of his pseudonyms. Dee was also the Queen's court astrologer, mathematician, and cartographer, often serving in that role under the name Gerardus Mercator. He gave his personal endorsement to the quest for a Northwest Passage, viewing it as a fit enterprise.

In June of 1576, Frobisher sailed three small ships as far as Baffin Island, where he sailed up an inlet called Frobisher's Bay today. He believed it to be a strait, with Asia on the north and America on the south. He was right about everything except the strait. It was not a strait in fact, but the Arctic Ocean. After losing a ship to the dangers of the sea, and a boat with five seamen to the Inuit, the expedition endeavored to reclaim some of its losses through a little mineral extraction, but the quantity was too small to prove profitable or productive. This sample delivered to Lok is believed to have contained gold debris.

Though the dream of a Northwest Passage was finally recognized for the pipedream it was, interest shifted to the possibility of a gold rush. Lord Sussex, the Earl of Leicester, Lord Burghley, Francis Walsingham, and Philip Sydney all lost money in the initial investment, but this did not stop them from throwing good money after bad. The Company of Cathay was chartered in March 1577. The Queen herself became the first to put up investment money as a Cathaian, which was the name the entrepreneurs gave themselves, as they were looking for the route to China known then as Cathay. The Queen herself put up an initial investment of $£ 100$ of the $£ 4,500$ required and even contributed a ship to the venture. The Countess Olivia in Twelfth Night would be called Cataian. Walsingham and Burghley weighed in with $£ 400$ and $£ 100$ respectively. Oxford was one of several who put up smaller sums to the tune of $£ 25$.

Embarking yet again, this time with a fleet of three, Frobisher sailed down the Thames in May of 1577 and returned with 200 pounds of ore. Despite the meager find, preparations were made to smelt the ore at Deptford. Lok had expected a yield of 40 pounds per ton and Sir John Dee signed a statement that he had obtained seven ounces of silver from 200 pounds of ore. Before the smelters had produced more than mere samples, which were in fact faked, an ambitious new expedition was announced, where 15 vessels would set off with intentions of founding a permanent mining camp and to bring back 2,000 tons of ore, after which
120 colonists would be dispatched to settle the area [119].

Doubtful of the enterprise, Lord Oxford held out until four days before the fleet sailed. He still clung to the belief that the real importance of the expeditions was to find the Northwest Passage, which had been the original intention. Commenting on the expedition, he wrote:

\section{BLOCK QUOTE BEGINS}

After my very hearty commendations: Understanding of the wise proceeding and orderly dealing for the continuing of the voyage for the discovery of Cathay by the north west (which the bearer, my friend Master Frobisher, hath already very honourably attempted and is now eftsoons to be employed for the better achieving thereof); and the rather induced, as well for the great liking Her Majesty hath to have the same passage discovered, as also for the special good favour I bear to Master Frobisher, to offer unto you to be an adventurer therein for the sum of 1,000 pounds or more, if you like to admit thereof; which sum of sums, upon your certificate of admittance, I will enter into bond, shall be paid for that use unto you upon Michaelmas day next coming. Requesting your answers therein, I bid you heartily farewell. From the Court, the 21st of May 1578.

Your loving friend,

Edward Oxenford [120]

\section{BLOCK QUOTE ENDS}

It should be noted that Oxford was now in bond for $£ 1,000$, but was soon to buy up an additional $£ 2,000$ worth of stock from Lok, bringing his investment to $£ 3,000$, just as Antonio in The Merchant of Venice is in bond for 3,000 ducats against the successful return of his vessels with rich cargos. This would make Oxford the biggest investor in the enterprise, and the one with the most to lose. He was doubtless duped into participating as a result of his naivety and complete lack of business sense, a wellknown trait of artists. He was probably tempted into the fiasco much like Antonio, who was cajoled at the very beginning of the play by his acquaintances, as the one here entreating him to invest:

\section{BLOCK QUOTE BEGINS}

Believe me, sir, had I such venture forth, The better part of my affections would Be with my hopes abroad, I should be still Plucking the grass to know where sits the wind, Peering in maps for ports, and piers and roads ... (Merchant of Venice, 1.1.15-19)

\section{BLOCK QUOTE ENDS} Salarino: 


\section{BLOCK QUOTE BEGINS}

My wind, cooling my broth,

Would blow me to an ague when I thought

What harm a wind too great might do at sea,

I should not see the sandy hourglass run

But I should think of swallows and of flats . . .

(Merchant of Venice, 1.1.23-27)

\section{BLOCK QUOTE ENDS}

Oxford's investment was enormous. Its loss would certainly have been as staggering to him as Antonio's in The Merchant of Venice. He knew he had been duped before the fleet even returned in November. The previous ore extraction from Hall's Island had been found to be utterly worthless. The company collapsed to the tune of $£ 20,000$. The interest on Lok's credit was extremely high, so Oxford bore the brunt of the blow. Frobisher declared Lok to be the con artist that he was, stating that he was "a false accountant of the Company, a cozenor to my Lord of Oxford, no venturer at all in the voyages, a bankrupt knave [121]." It is often suggested that Lok may have been the inspiration behind Shylock from The Merchant of Venice. It does appear that, in his readiness to part with $£ 2,000$ of his $£ 5,000$ investment to Oxford, he may have had prior knowledge of the probable value of the ore, as Frobisher alleges.

\section{Henry IV Parts 1 and 2}

In 1583, Oxford's old nemesis, Henry Howard, had been arrested. In fact, the exposure of the Throckmorton plot to replace the Queen with a Catholic monarch had led to the defeat of all of Oxford's Catholic enemies. Doubtless exhilarated by this happy turn of events, it may have prompted him to write Henry IV, Part 1, where Prince Hal and company have a frolicking good time. In the original version of this play, Prince Hal's immortal comic creation, Falstaff, would be called Sir John Oldcastle. The name "Oldcastle" probably implies old feudal England, which was beginning to fall into ruin like the old derelict castles scattered around the kingdom that were now abandoned or falling into disuse. The rising merchant class was rendering the old feudal system obsolete, which was a relief to merchant and peasant class alike. Sir John Oldcastle became Sir John Falstaff, perhaps alluding to Shakespeare's fallen state late in life as a "Fall-staff," implying impotence and a fall from grace. However, it is also very likely that "False-staff" or "False-Speare" is implied, which would be a reference to Will Shakspere, who was a mere stand-in for Shakespeare, a pseudo-Shakespeare to be sure.

1584 is the date assigned to the play by Shakespeare scholar Eva Turner Clark, who argues that the rebels in the play, the Perceys and Worcester, are composites of both the rebellious earls in the Northern Uprising and the recently imprisoned Howards in 1583. The objective of the Northern Uprising and the Throckmorton Plot differed very little. Both sought the deposing of Queen Elizabeth I, who was a protestant monarch, in favor of a Catholic one. It is very likely that the bitter and angry counsel Prince Hal receives at the hands of King Henry was little different in tone from the drubbing Oxford received for the low company he kept by cavorting with commoners and common players, for he asks with the interest of a good friend as opposed to just a paternal figure, how:

\section{BLOCK QUOTE BEGINS}

Could such inordinates and low desires,

Such poor, such bare, such lewd, such mean attempts, Such barren pleasures, rude society,

As thou art mach'd withal and grafted to,

Accompany the greatness of my blood,

And hold their level with thy princely heart?

(Henry IV, Part 1, 3.2.14-20)

\section{BLOCK QUOTE ENDS}

To which the prince protests:

\section{BLOCK QUOTE BEGINS}

... God forgive them that so much hath sway'd Your Majesty's good thoughts away from me . . . (Henry IV, Part 1, 3.2.130-131)

\section{BLOCK QUOTE ENDS}

He then promises to exact harsh vengeance upon his father's enemies as:

\section{BLOCK QUOTE BEGINS}

... may salve

The long-grown wounds of my intemperance.

(Henry IV, Part 1, 3.2.156)

\section{BLOCK QUOTE ENDS}

Having endeavored to win back the favor and the trust of Queen Elizabeth with the Henry plays, he shows his true persona to the Queen in Prince Hal, who defeated the renowned warrior, Henry Percy, known as Hotspur, thus saving his father's throne, as Oxford is likely to have thought he saved Elizabeth's by exposing the Howards' role in the Throckmorton Plot. Having won the prize in the tournament of 1581, in which Oxford had defeated a great champion to win the honors, grants the analogy even more validity.

The point Oxford seems to be making in the Henry plays, is that nobility is not an attribute so much born in a man as won through noble pursuit. Thus, Prince Hal's undisciplined youth, tavern life, practice of consorting with low company, his impudence, recklessness, and constant affronts to respectability, make him all the more noble, having passed through a rite of passage to define his own standards of what true nobility consists of by challenging the status quo. This is a point Oxford would have liked to make being very proud by temperament. In essence, he is reclaiming the dignity he had lost in the eyes of the Court. What the 
Archbishop of Canterbury says of Prince Hal applies perfectly to Oxford:

\section{BLOCK QUOTE BEGINS}

But that his wildness, mortified in him,

Seem'd to die too ...

Never was such a sudden scholar made,

Never came reformation in flood,

With such a heady currance, scouring faults.

(Henry IV, Part 1, 1.1.27-35)

\section{BLOCK QUOTE ENDS}

The Shakespeare dramatist shows Prince Hal repenting. In fact, both Tudor princes, Bacon and Oxford would have some cause to repent and redeem themselves in the eyes of their mother, the Queen. The Bishop of Ely says: "We are blessed in the change." The Archbishop of Canterbury's praise of Prince Hal's nobler qualities would equally well apply to the man we know as Shakespeare:

\section{BLOCK QUOTE BEGINS}

Hear him but reason in divinity,

And all-admiring with an inward wish

You would desire the king were made a prelate:

Hear him debate of commonwealth affairs,

You would say it had been all in all his study:

List his discourse of war, and you shall hear

A fearful battle rendered you in music:

Turn him to any cause of policy,

The Gordion knot of it he will unloose,

Familiar as his garter: that, when he speaks

The air, a charter'd libertine, is still,

And the mute wonder lurketh in men's ears,

To steal the sweet and honey'd sentences ...

(Henry IV, Part 1, 1.1.40-52)

\section{BLOCK QUOTE ENDS}

One can scarcely imagine these words being spoken of a prince. They are more apropos of a poetwarrior, diplomat, courtier and consummate politician, who has turned a multi-faceted life into sweet poetry, a golden harvest of philosophy that both Tudor princes could claim as their bounty. The Archbishop of Canterbury's amazement of the fact that Prince Hal has been able to acquire such virtues in such low company could really only be inspired by one candidate of the Elizabethan Court, the Earl of Oxford:

\section{BLOCK QUOTE BEGINS}

So that the art and practice part of life

Must be the mistress of this rhetoric:

Which is a wonder how his grace should glean it,

Since his addiction was to courses vain,

His companies unletter'd rude and shallow,

His hours fill'd up with riots, banquets, sports . .

(Henry IV, Part 1, 1.1.53-58)

\section{BLOCK QUOTE ENDS} quandary:

Ely provides the answer to the Archbishop's

\section{BLOCK QUOTE BEGINS}

The strawberry grows underneath the nettle, And wholesome berries thrive and ripen best Neighbor'd by fruit of baser quality . . .

(Henry IV, Part 1, 1.1.62-64)

\section{BLOCK QUOTE ENDS}

A Buddhist might use a different turn of phrase, referring to the lotus that grows best in murky waters with its roots firmly planted in the mud. Indeed, the enlightenment that Oxford transferred to his other persona as the immortal Bard is one that could only be fostered through adversity, a wisdom that saw through the pretentions of men in recognition of what true honor consisted in, a wisdom that sought not to elevate itself above the common man, but to recognize that everyone is equal, it is just that, paradoxically, some are better at being equal than others.

In Henry IV, Part 1, we see the Tudor princes' old friend, Sir John Dee, reappear in the character Owen Glendower. Historically, Sir Humphrey Gilbert had assigned Dee with all his rights to lands north of the $50^{\text {th }}$ parallel in North America, which actually cuts through Northern Newfoundland. This was likely in payment for services rendered, since Dee was busy drawing maps, which showed passages through and around America, both in the Arctic and in more temperate latitudes. He was also engaged in conducting séances to call upon supernatural guidance for the successful discovery of the Northwest Passage to the Orient. Thus, in Henry IV, Part 1, almost contemporaneously, we have the magician-warrior Owen Glendower announcing that he "can call spirits from the vasty deep" and in Hotspur's ironic retort, "But do they come when you call for them?" (Henry IV, Part 1, 3.1, 52-54) we see a probable reflection of the Tudor princes' own experiences with the magician, who they lampoon for his oft impotent magic wand.

The application for a patent authorizing a search for the Northwest Passage, which Dee must have made, now fell to Humphrey Gilbert's brother Adrian. Adrian Gilbert was the half-brother of Walter Raleigh and together they organized The Colleagues for the Fellowship for the Discovery of the Northwest Passage. With Earls Leicester and Bedford, Oxford became a shareholder in the new company. John Davis was engaged as the navigator of the mission. With the ships Sunshine and Moonshine, Davis set sail in June 1585 to return in September, having made Baffin Island north of Frobisher's explorations and sailed up Cumberland Sound. This he took to be the strait he was seeking and returned with renewed hope of finding the Northwest Passage, but there was nothing more to compensate the stockholders with than this flimsiest of whims. As the 
brainchild of the author investor, Hamlet would have reason to lament, "I am mad north northwest." But the worldly misfortunes of artists are what tend to grant them greater fortune in their artistic works. Oxford's interest in and geographical knowledge of the area known as North America would find expression in The Tempest [122]. One should also remember that this interest is one he shared with his half-brother Sir Francis Bacon, who had written the plan for the new continent into his great work The New Atlantis.

\section{Background for The Tragedy of King Lear}

Late in life, Oxford conceived a hair-brained proposal to have his father-in-law, William Cecil, intercede with the Queen to have his annuity of $£ 1000$ cancelled in order to accrue an immediate sum of $£ 5,000$ to enable him to buy a property with a yearly rent of $£ 230$. Alternatively, he would have the Queen advance the sum against his hereditary claim to the Forest of Essex. In his words, he said he "would be glad to be sure of something that were mine own" and "to have an equal care with your Lordship over his children," to which if the proposal were accepted, he would devote some $£ 500$ or $£ 600$ a year. He even expounded on his aims concerning his children's security in a letter:

\section{BLOCK QUOTE BEGINS}

So shall my children be provided for, myself at length settled in quiet, and I hope your Lordship contented, remaining no cause for you to think me an evil father, nor any doubt in me but that I may enjoy that friendship from your Lordship that so near a match, and not fruitless, may lawfully expect. Good My Lord, think of this, and let me have both your furtherance and counsel in this cause. For to tell the truth, I am weary of an unsettled life, which is the very pestilence that happens unto Courtiers, that propounded unto themselves no end of their time therein bestowed [123].

\section{BLOCK QUOTE ENDS}

Whatever Oxford's intentions may have been, he had no head for business and the Queen must have seen fit to keep the annuity of $£ 1,000$ a year coming. Hedingham was one of the properties that was by Oxford's calculations supposed to produce $£ 5,000$ or $£ 6,000$ for his daughter's maintenance, though his plan came to naught. Hedingham served as the family's residence nevertheless. In 1591, the Earl made it over to Burghley in trust for his daughters. At the same time, he authorized the dismantling of several of the cottages and outbuildings, which had probably fallen into ruin as a result of gross neglect. A reliable report issued 200 years after the fact alleged that Oxford had ordered the demolition to spite his father-in-law. The parallel to King Lear is too striking to ignore. 'Lear' is an anagram of 'Earl'; hence it identities him as the true heir to the throne as "King Earl." Lear, whose intention was to hand over his kingdom and his castle to his three daughters, must have been on the author's mind when he chose the story of the play from Geoffrey of Monmouth and Holinshed. Castle Hedingham, Lord Oxford's castle home, was also on the author's mind as evidenced by the fact that the Fool's chiding of the homeless monarch with "a snail has a house . . . to put's head in, not to give away to his daughters. He that has a house to put his head in had a good headpiece." (King Lear, 3.2.25-26) The expression "head in" is suggestive of Hedingham, a punning piece of wordplay [124]. Whichever of the two Tudor princes penned the play, it seems obvious that the story line is collaborative and that the Tudor princes drew inspiration from the plot from the circumstances found in this stage of Lord Oxford's life.

Oxford's estate troubles date to about 1582 . Another play, Timon of Athens, charts the downfall of a man who cannot manage power, money or responsibility. The title character is a prodigal patron and compulsive spendthrift. The first half of the play has him depleting his resources, while the second half has him discovering how many fair-weather friends rush for the exits when he's suddenly out of pocket. However, before Timon's final downfall, he has to face some painful and hard truths from his faithful steward Flavius. The wastrel learns that his dwindling estates cannot cover his mounting debts, a gloomy fate that perfectly matches the Earl's situation at this time. "Let all my land be sold!" bids Timon, to which Flavius replies, "'Tis all engaged, some forfeited and gone,/And what remains will hardly stop the mouth/Of present dues." (Timon of Athens, 1.1.)

Flavius, knowing his master is given to fits of irrational distemper, defends his actions as those of a true and steadfast accountant. "If you suspect my husbandry or falsehood," Flavius urges, "Call me before the exactest auditors/And set me on the proof." (Timon of Athens, 1.1) This is exactly what Bacon's and Oxford's secretary, John Lyly, was going through in the summer of 1582. And it should be remembered that Bacon biographer Alfred Dodd alleged that Francis Bacon used the name John Lyly as one of his pseudonyms. The fact that Lyly has such an intimate connection to both Tudor princes once again points to a collaborative relationship between them. As Oxford's financial difficulties continued to mount, he deflected much of the blame unfairly on the keeper of his accounts, John Lyly. In July of that year, Lyly wrote to Lord Burghley, begging for the Lord Treasurer's intercession. Since Lyly was asking for audits of his accounts, the secretary was clearly serving as the Earl's bookkeeper. By October 1582, Oxford was casting himself out of the city gates, withdrawing to his ancestral home as the lord of the manor of Castle Hedingham. He and the Countess, Anne de Vere, now made the castle their home [125]. 
We know from the previous chapter what became of Lord Oxford. He faked his death in 1604 at the behest of King James I, and lived in exile on the Isle of Mersea for many years, till the time of his actual death, which apparently occurred in 1609. Lord Bacon lived on. And as the timeline of the publication of the play quartos and folios suggests, Lord Bacon was the only one of the three favored candidates, who could have published these late editions. What is also clear is that he acted in the capacity of editor, which gave him the authority to make amendments and additions to the plays, which he did. This does not diminish the role played by his half-brother and fellow Tudor prince, Edward de Vere, the 17th Earl of Oxford. If indeed Bacon was the primary author, it is obvious that fellow Tudor prince Oxford provided story line fodder with his uniquely Bohemian lifestyle. Even the much-denigrated figure of fun, Will Shakspere, played his part it seems by not only acting as frontman, but by contributing to the writing team through storytelling and hamming, relating the hijinks of Warwickshire life to his royal cousins, whom he was related to through the Arden family.

While arguably offering poor support for the theory purported in the preceding paragraph, there is an interesting account which supports the same conjecture. During the 1940s, Oxfordian Percy Allen decided that the best way to resolve the authorship dispute, at least for his own purposes, was to rely on spiritual mediumship to contact the Elizabethan Period directly. With the aid of spiritual medium, Mrs. Hester Dowden, who just happened to be the daughter of a Shakespeare scholar herself, Allen was able to establish an automatic writing link to Bacon, Will Shakspere of Stratford, and the 17th Earl of Oxford by means of a guide named "Johannes." Allen verified that the Shakespeare plays were a collaborative effort by all three. Shakspere from Stratford had the ham-like acting skills to act out some amusing comedy sketches, while Oxford would flesh out the characters and the written plot. The duo would then submit their collaborative effort to Lord Bacon for review [126]. In essence then, the argument is made through this encounter with the supernatural that Bacon was the editor of the Shakespeare works, which is supported by the scholarly evidence provided elsewhere in the chapter, which shows that editing of quartos and the First Folio took place up to 1623, with substantial revisions and additions being made, long after Lord Oxford and the Stratford man were in their graves. The only candidate still alive with the erudition and talent to revise and edit the Shakespeare works was Francis Bacon.

Francis Bacon died on April 9, 1626, at 66 years of age, in the early morning of Easter Sunday, three years after the publication of the Shakespeare Folio of 1623. He died in the Earl of Arundel's house in Highgate, near London, where he was taken after catching a bad chill, which developed into pneumonia
[127]. Apparently, his Lordship's death was the result of him conducting cold experiments for the preservation of meat using snow. He was out taking the air in a coach with Dr. Witherborne, a Scotchman of his acquaintance, and Physician to the King. They were riding towards Highgate, with snow on the ground, when it suddenly occurred to Bacon that flesh could be as effectively preserved in snow as in salt. Being men of science, he and the good doctor decided to proceed with the experiment.

They alighted from the coach, and proceeded up to the door of an old woman's humble cottage at the bottom of Highgate Hill. There, they procured a hen and paid her for it. They urged the hen woman to exenterate it, after which they stuffed the bird with snow, Bacon assisting in the procedure. Unexpectedly, the snow so chilled him that he immediately fell deathly ill, and was unable to find the energy to return to his own lodgings at Gray's Inn. Instead, he was taken to the Earl of Arundel's house at Highgate, where he was laid in a bed warmed by the servants with a bed pan. However, the bed was damp as it had not been slept in for two years, causing the cold to invade his lungs. His lungs full of fluid, he succumbed to the effects of pneumonia within three days [128].

\section{References to Freemasonry in Shakespeare}

Sir Francis Bacon was not only the Chancellor of England, Grand Patriarch of Freemasonry, and founder of the Rosicrucian Society, but also the founder of HMSS. And based on the evidence, it appears that half-brother and fellow Tudor prince, the Earl of Oxford, worked for that same secret service. The evidence of a Privy Seal Warrant issued on his behalf supports the view that Lord Oxford was acting as an agent of the British secret service. The year 1586 was a watershed in the earl's life. He was endowed with a pension from that year until the end of his life that would commit him wholly to the staging of theatrical productions for Her Majesty's Court. Nothing would distract him from his enterprise except for the occasional intervening military adventure. On June 26, 1586, the Queen signed a Privy Seal Warrant, shared earlier in the chapter, requiring that the Earl of Oxford be paid a substantial annuity. Let's study the warrant a second time just to grasp its full implications:

\section{BLOCK QUOTE BEGINS}

Elizabeth, etc., to the Treasurer and Chamberlains of our Exchequer, Greeting. We will and command you of Our treasure being and remaining from time to time within the receipt of Our Exchequer, to deliver and pay, or cause to be delivered and paid, unto Our right trusty and well beloved Cousin, the Earl of Oxford, or to his assigns sufficiently authorized by him, the sum of One Thousand Pounds good and lawful money of England. The same to be yearly delivered and paid unto Our said Cousin at four terms of the year by even portions: and so to be continued unto him during 
Our pleasure, or until such time as he shall be to Us otherwise provided for to be in some manner relieved; at what time Our pleasure is that this payment of One Thousand Pounds yearly to Our said Cousin in manner above specified shall cease. And for the same or any part thereof, Our further will and commandment is that neither the said Earl nor his assigns nor his or their executors nor any of them shall by want of account, imprest, or any other way whatsoever be charged towards Us, our heirs and successors. And these Our letters shall be sufficient warrant and discharge in that behalf. Given under Our Privy Seal at Our Manor of Greenwich, the six and twentieth day of June in the eight and twentieth year of Our reign [129].

\section{BLOCK QUOTE ENDS}

What seems clear from the warrant is that the Chancellor of the Exchequer is being asked to issue a substantial sum annually to Lord Oxford, for which no bookkeeping is required, which is a telltale sign that he is being paid as a secret agent or spy by the intelligence services. Why would the Earl of Oxford be paid by HMSS and not through some more transparent organ of the government? Elizabeth's customary practice was to reward men for their faithful service-men like Leicester, Hatton, Raleigh and Essex-by presenting them with gifts of land or monopolies. It should be noted that the grant of $£ 1000$ continued after the accession of King James I. The 18-year term of the grant would last until the time of his "official death," since he faked his death in 1604 , and was sent to live out the remainder of his natural life on the penal island of Mersea in a deal forged with King James I-who would not allow him to live in England knowing he existed as a threat and rival claimant to the throne-as the firstborn illegitimate son of Queen Elizabeth I. It is something of an enigma to researchers that such a generous endowment should be offered to the earl in the first place, since the only official office he occupied at the time was as a member of the Privy Council of the House of Lords. How can one explain why he should be receiving such an annuity, which amounted to four times the prime minister's salary in today's terms? The only logical answer is that Oxford was being paid by the intelligence services indirectly from the Chancellor of the Exchequer for services rendered. Why would he be paid by a clandestine organization like HMSS unless he was working undercover as an agent of that very organization? What was the nature of this intelligence work? He is known not to have traveled abroad from 1586 until the end of his life, so whatever the nature of the espionage work, it was conducted at home. We have already seen how he had brought the life of foreign and domestic courts to the stage. Could his work have consisted of writing for a guild, a propaganda ministry of the British Crown, serving as a propagandist for Queen and country and later King and country?
The Tudor princes were both Freemasons as evidenced from references they made even in writings published under their own names. The hundreds of references appearing in the Shakespeare plays to Freemasonry show the obvious influence of Freemasonry on the author(s). There is also considerable evidence that the Shakespeare plays were a joint effort orchestrated by their patrons, Lord Oxford and Sir Bacon. The Northumberland Manuscript is just one of the documents linking Francis Bacon to the plays. It is also known that both Tudor princes attended Gray's Inn Law School, where Shakespeare plays as well as masques and revels authored by Lord Bacon were performed. Bacon became Gray's Lord Treasurer and had chambers there from 1576 until his death [130].

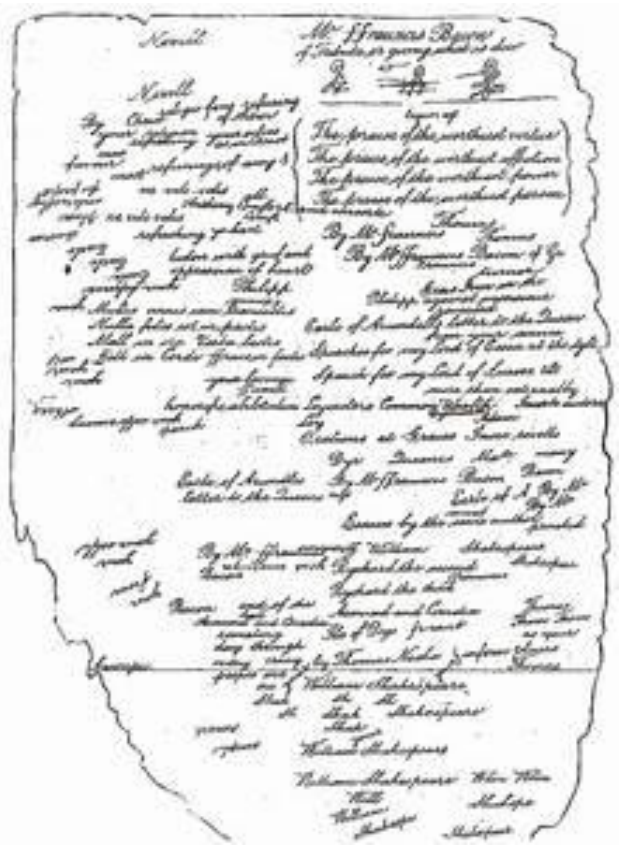

\section{Northumberland Manuscript found among Bacon's personal effects}

Temple Bar is the name of the legal district in the City of London, a one square mile city-within-a-city where the five Inns of Court are located. The expression "Bar Exam" obviously derives its name from the location. Temple Bar gets its name from the organization that founded it, the Knights of the Temple or Knights Templar. Gray's Inn is one of five Inns of Court, along with Lincoln's Inn, the Inner Temple, Middle Temple and Outer Temple. It is believed the Inns were founded in the 13th century. These former Inns of Court, now the pillars of the London legal district, are intimately connected with Freemasonry, which descends from the Knights Templar. To study law and become a barrister would have made it incumbent upon one to be a Freemason traditionally. This was true even of Mohandas Karamchand Gandhi, aka Mahatma Gandhi, who studied law at the Inner Temple early in his career, and whose London Diary, only 20 pages of which remain extant, appears to be his Freemason diary as will be explained later in the book. 
The Inns today maintain the appearance of academic campuses. They are an anachronism from the past, granting peace, serenity and sanctuary with their manicured greensward and flowerbeds. The gardens of Middle Temple, sloping down to the River Thames embankment, like those of the adjacent Inner Temple, where Gandhi studied, are planted with roses just as they were in 1455, when the Yorkists and Lancastrians began the War of the Roses, when each side plucked a Temple rose in order to take sides [31].

In Troilus and Cressida, there are repeated references made to the occult beliefs of Freemasonry. Allusions to 'degree' and its importance are made several times in this and other plays. To Shakespeare, obedience to rank and degree adheres to an order found in nature itself as these lines spoken by Ulysses convey:

\section{BLOCK QUOTE BEGINS}

The heavens themselves, the planets, and this center Observe degree, priority and place,

Insisture, course, proportion, season, form, Office, and custom, in all line of order; And therefore is the glorious planet Sol In noble eminence enthron'd and spher'd Amidst the other.

(Troilus and Cressida, 1.3.85-91)

\section{BLOCK QUOTE ENDS}

As mentioned earlier, Sol is Latin for 'Sun.' The religion of classical Rome, the Sol Invictus cult consisted of Sun worship. Some believe Sun god worship to be a front for the worship of Baal aka the Fallen Angel, Lucifer. The Freemason Order is pagan in orientation and worships the sun as its highest principle. The Sun is the king of the planets, and the King, who rules by divine right, is considered the incarnation of the Sun god. As higher degree Freemasons have the bloodline of kings, the purity of the bloodline is considered sacrosanct. The degrees of Freemasonry are meant to preserve the purity of the bloodline. Shakespeare writes that degree and rank must be adhered to lest, as the character Ulysses says, in Troilus and Cressida, disease and disorder reign:

\section{BLOCK QUOTE BEGINS}

$\mathrm{O}$ ! when degree is shak'd

Which is the ladder to all high designs,

The enterprise is sick ..."

(Troilus and Cressida, 1.3.101-103)

\section{BLOCK QUOTE ENDS}

In his youthful poem, "Labour and Its Reward," Oxford, naming himself as the author, writes:

\section{BLOCK QUOTE BEGINS}

The Mason poor that builds the lordly halls Dwells not in them: they are for higher degree ... [132].

\section{BLOCK QUOTE ENDS}

Oxford is referring to the degree system of Freemasonry, which assigns privilege to those of higher degree, and those who occupy a higher aristocratic rank or bloodline, those whose royal blood is deemed to be purer and who are initiated into the higher degrees based on their blueblood roots. What seems to be implied by the title, "Labour and Its Reward," as well as the lines of verse, is that Oxford is lamenting the fact that he cannot enjoy the privilege of those of higher degree, probably due to his illegitimate birth. While being a member of the royal family by blood, his illegitimate birth disqualified him from obtaining the rank of prince. As a Freemason, he is honor bound to not only maintain the secrets of the Order, having taken a pledge to do so - a pledge accompanied by a series of degree oaths to keep the pact on pain of death-but must also comply with what higher initiates within the Order require of him. It is not at all far-fetched to suppose that Oxford had been required, on the basis of his Freemason and secret society oath-taking as well as his life as a secret agent of HMSS, to maintain the secrets of the Order. The fact that Oxford seems to lament the anonymity he is forced to maintain is clear in two lines found near the end of the poem:

\section{BLOCK QUOTE BEGINS}

So he that takes the pain to pen the book Reaps not the gifts of godly golden muse ... [133].

\section{BLOCK QUOTE ENDS}

Having taken the fraternal oaths of the Freemason and Rosicrucian Orders, as well as other secret societies to which they were attached-i.e. Fra Rosi Cross or The Honourable Order of the Knights of the Helmet - the Tudor princes, Oxford and Bacon would not write freely and of their own volition, but as the intelligence men and members of the fraternal orders to which they belonged. Patriotic duty would have required them to be "martyrs" in the cause of nationhood and empire-building. As for "Labour and Its Reward," there would be none. The Shakespeare play, Love's Labour Lost, makes a similar allusion, implying that the author's labor of love knows no reward, but is lost. To labor without the expectation of reward and to be denied the fruits of one's ardor was a Rosicrucian ethic, one that, as members, both Tudor princes would have adhered to. They would be denied all glory and would not receive recognition for their work.

Instead, they would author plays and poetry as intelligence men, state propagandists, and agents of HMSS. They would be dispatched on intelligencegathering missions to the Continent, enjoying diplomatic immunity as ambassadors, while covertly spying and gaining intelligence on the Courts of Europe, so as to cast them in a disparaging light in the plays. They would also appropriate institutions of the Continent like the Italian sonnet and the masterpieces of Ovid, Plutarch and others, and supersede them in 
mastery and genius, exacting a cultural coup on the Continent that would leave England sitting prettiest as the cultivator of the greatest "writer" in European history, and as far as the Continent would be driven to think, a commoner to boot, which would be the ultimate turning of the tables, a cultural coup.

The half century period from 1576 to 1625 is unique in English history. Not only was the English language in its modern form canonized, but the greatest literature produced in the new tongue came from the same period. In addition, the knowledge and wisdom of the classical writers, the histories of great nations, and practically anything that was worth knowing in the literature of other countries was shared during this period. Something or someone had to be the driving force behind this, someone with vision and insight beyond the ken of his contemporaries, who could see across vistas to the past and who had an equally penetrating vision of the future.

The efforts at translation of works from the continent was prodigious, with efforts to cover the gamut in terms of knowledge, in the spirit of Francis Bacon's claim, "All knowledge is my province." There were also books published during this period that covered a huge range of eclectic learning in esoteric subjects and hermeneutic wisdom. There is no translator listed on the title page of many of these books. An astonishing number of scholars affixed their names to one book during this period and then disappeared from the pages of history [134].

It was the custom of the Elizabethan period for an author to suppress his authorship of a certain work. Instead, he would substitute either the initials or name of some other person on the title page. The title pages of this period are as unreliable as are the names or initials appearing in the dedications and epistles "To the Reader." In 1624, for instance, the dedication to, The Historie of the Life and Death of Mary Stuart Queene of Scotland, is signed Wil Stranguage [135]. The surname appears to be a word coined from the hybridization of the words "strange" and "language." "Wil" was a commonly used abbreviation for "William" in reference to William Shakespeare. In all likelihood, the volume was authored by Sir Francis Bacon, who wished to keep his authorship so secret it would not be accredited to William Shakespeare, whose works were known to be of a dramatic nature only, and not works of scholarship. In 1636, the same work was reprinted, this time with the dedication W. Vdall [136].

\section{Shakespeare and Speculative Freemasonry}

Speculative Freemasonry was born in the Elizabethan era. The story of its birth is told in the Shakespeare Folio of 1623, considered the greatest Masonic book in the world. The secret was buried and the mystery left to germinate like a bulb in the ground till it was ready to emerge from underground a century later. Speculative Freemasonry did not reach full bloom until 1723 as planned. It was predetermined that it would germinate in the 1623 Shakespeare Folio. The authors of the Shakespeare works were not merely Freemasons. They were a group of individuals who surrounded and included the founder and progenitor of modern Speculative Freemasonry, Sir Francis Bacon, the mastermind behind the writing of the mini-dramas that are embodied in its $33^{\circ}$ rituals, which are in turn based on the Elysian Mysteries.

In a letter to Ben Jonson, Bacon wrote: "What things have we seen, Done at the Mermaid! Heard words that have been, so nimble and so full of subtle Flame . . . One had resolved to live a F . . . the rest of his dull life [137]." The reference to Freemasonry is beyond question: These words reflect the fact that Ben Jonson and Francis Bacon were both Masons. They were also very likely, by connection, members of HMSS, and other affiliated clandestine organizations. This explains the role Jonson seems to have played in the cover up, reflected in the dedications he masterminded in the Shakespeare Folio and the Sonnets.

That Sir Francis Bacon had a hand in the plays is beyond question. The Northumberland Manuscript would attest to that. It is certain that he would have had a strong philosophical, esoteric and occult influence upon the writing of the plays, many of which were written by himself, though he appears to take full credit for them in his embedded cipher biography, as was shown earlier in the chapter.

Peacham's Minerva Britanna has an emblem appearing on page 34 , which is addressed "To the most judicious and learned, SIR FRANCIS BACON KNIGHT." On the opposite page, whose pagination is rendered " 33 ." This probably stands for $33^{\circ}$, as that is the highest degree in the Freemason degree ranking system. "33" also happens to be the numerical value of the name "Bacon." Page 33 features a design representing a hand holding a spear, which appears to be in the act of shaking it. But it is the frontispiece of this edition that bears the most important and significant design feature. A curtain is partly drawn, concealing the figure standing behind it, with only the hand holding the curtain visible. That same hand has just written the words: "MENTE VIDBOR," meaning "By the mind I shall be seen." Around the scroll, the following words appear: Vivitur ingenio cetera mortis erunt, "One lives in one's genius; other things shall pass away in death [138]." 


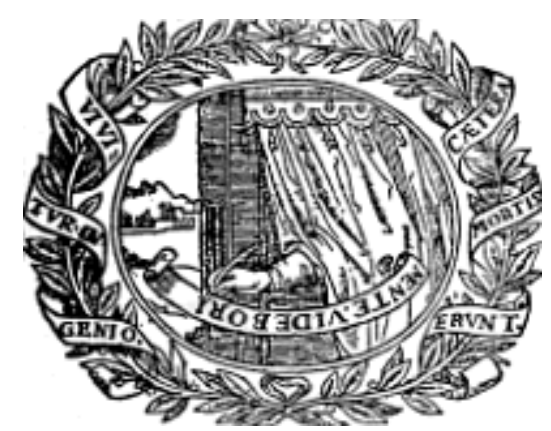

An engraved illustration of the goddess Athena appears on the title page of the 1641 French edition of Francis Bacon's Wisdom of the Ancients. The illustration shows Pallas Athena seated on a small stage, the stage of the mysteries, over which she and her male counterpart, Apollo, preside. In her right hand, she holds the well-known spear, which she brandishes at the serpent of ignorance, while her left hand rests atop her polished shield. She wears her aegic or breastplate and her plumed helmet, symbol of illumination. Made for her by Pluto, god of the Underworld, it is the helmet she bestows on all her heroes who attain the quest, thereby becoming "Knights of the Helmet." Representing their illumination, it also symbolizes secrecy and invisibility. It is Pallas Athena's Helmet of Invisibility after all, since each time she drew the visor down over her face, she became invisible. The name "William" derives from the German "Wilhelm," meaning "helmet." Initiates of Francis Bacon's fraternal order, The Knights of the Order of the Helmet, kissed the helmet and placed it on their heads when they joined, rendering themselves one of the newly inducted Invisibles in the process. All initiates of the writing guild were required to remain invisible, writing under pen names or anonymously, avoiding vanity at all costs.

Inscribed on Athena's shield is the Latin motto, Obscuris vera involens, "Truth is enveloped in obscurity," which explains the imagery of the shieldthe central sun representing the truth, and the surrounding clouds, obscurity. Above Athena's head are three lamps, each burning with a lighted candle, signifying the Holy Trinity. The Latin motto associated with them, written on the scroll directly over the goddess's head, reads sic fulget in umbras, "Thus it shines in the shadows," a hint that the light of truth shines in the shadows of the world in an obscure and veiled way. It is shown here associated with the stage, the theater of the mysteries, on which the allegorical dramas of life were enacted in classical times under the auspices of the goddess Pallas Athena, the archetypal "Spear-shaker." This was the preeminent method of educating by means of which the ancient wisdom was taught. Bacon, a great admirer of the theater for such purposes, invariably put into practice whatever he thought was useful for the benefit of humanity and believed he was following the practices of the ancients by doing so. He was even referred to as Athena by his literary contemporaries. Athena was the patron goddess of Freemasonry as well as the Greek theater. She was most certainly the inspiration behind the name Shakespeare, as she was the patron goddess of Greek drama and was nicknamed the Spear-shaker [139].

\section{Masonic Allusions in The Plays BLOCK QUOTE BEGINS \\ Reference to Masonic Temples}

"And the meanest things are made more precious when they are dedicated to Temples."

(Epistle Dedication in the Shakespeare Folio of 1623)

\author{
The Masonic Shroud \\ "Like to the garter COMPASSE in a ring ..." \\ (Merry Wives of Windsor, 5.1)
}

\section{The Young Mason}

"Is there no young squarer that will make a voyage with him?"

(Much Ado About Nothing, 1.1)

\section{Square Conduct}

"I have not kept my Square, but that to come shall all be done by Rule."

(Antony and Cleopatra, 2.1)

"They never met, but by the Square."

(A Midsummer Night's Dream, 2.1)

\section{The Prepared Candidate}

"I shall stay here, therefore horse to a Smock creaking my shoes on the Plain Masonry."

(All's Well That Ends Well, Act 2, final scene)

"Be patient ... I'll bring thee ... Hoodwink this ... speak softly ... This is the Mouth of THE CELL . . . No more ... ENTER."

(The Tempest, Act 4)

\section{Master Mason \\ "What! My old Worshipful Master!" \\ (Taming of the Shrew, 5.1)}

The Point From Which a Master Mason Cannot Ere "I will find where the TRUTH is Hid

Though it were Hid indeed

Within the Centre."

(Hamlet, 2.2)

\section{BLOCK QUOTE ENDS}

One of the greatest fallacies is that the general consensus, prevailing opinion and time-honored beliefs hold a prerogative and a monopoly on truth. This logical fallacy is known as the bandwagon argument. There are many intelligent, well-educated people who refuse to look at new information that calls into question their preconceived notions of what is true. Is it progressive or even mature to refuse to look at evidence that contradicts one's beliefs? Worse still is the fact that political correctness has made it impolitic to question the prevailing point of view. The bandwagon argument now holds virtually dictatorial powers. Then there are 
the millions of uneducated, unreflecting people, who adopt views based on hearsay, and the fallacy of timehonored tradition, whose majority opinion disqualifies the view of one genuine expert, a person who researches, reflects and thinks as a sovereign individual rather than embracing the view of what Nietzsche called "the herd-animal morality."

It was only in the $19^{\text {th }}$ and $20^{\text {th }}$ centuries that the profound classical and renaissance learning, as well as vast knowledge of jurisprudence, medicine, botany, biology, geography, cosmology, astronomy as well as direct experience of state and court life exhibited in the plays became recognized by Shakespearean scholars and enthusiasts of Elizabethan England. The plays and poems evidence a planned spiritual revelation orchestrated with boundless patience to be revealed through time in slow increments. The first task would be to imbed clues in the plays that would function as a kind of time capsule that would encompass the age and body of the time as something to be understood by a more enlightened population of the future in possession of the mental arithmetic, acumen and lexicon capable of understanding the mind and the personage(s) behind the plays. The true author(s) would insert ciphers or codes that would permit revelation to come forth at some later juncture on the historical timeline. It would be a kind of rebirth occurring through time at the appointed juncture, a phoenix rising, reconstituting its nest, its life, its existence as part of a coming forth or reemergence.

Another way for the renaissance mind(s) who authored the plays to reemerge and be reborn is to embrace a seasonal motif, in which a long winter would be replaced by a glorious rebirth in the spring. Hence the myths of Demeter and Persephone/Proserpine are rife in the plays. For this reason, plays like The Winter's Tale incorporated the myth of Demeter and Persephone carefully veiled and artfully disguised as Hermione and Perdita in the play [140]. We have other rebirth motifs employed in other Shakespeare works, such as The Phoenix and the Turtle, and Shake-speares Sonnets. The plays have an undercurrent of mystery and unrevealed revelation, written and concealed for posterity to discover. The silence, secrecy, mystery, discretion and reserve that epitomized Francis Bacon, who lived the Rosicrucian doctrine that fit him to the letter, pervades the plays whose authorship he oversaw and even participated in. The implied secrecy and withheld revelation are integral parts of a planned system, which were the product of gods of art, sacrificing or martyring themselves-denying themselves any credit whatsoever for the worksconcealing themselves behind and in the works, only to be discovered at some later point in history [141].

In planning the "philosophical system of plays" that he and his poet genius half-brother, Edward de Vere, fellow changeling son of Queen Elizabeth I, Lord Bacon intended to keep a body of his work secret as a sacred preserve. In the Magna Instauratio (Great Instauration), he hints at the necessity of secrecy and the need to keep an element of his work hidden:

\section{BLOCK QUOTE BEGINS}

That the discretion anciently observed, though by the precedent of many vain persons and deceivers abused, of publishing part and reserving part to a private succession, and of publishing in such a manner whereby it would not be to the taste or capacity of all, but shall as it were singe and adopt his reader, is not to be laid aside; both for the avoiding of abuse in the excluded, and the strengthening of affection in the admitted [142].

\section{BLOCK QUOTE ENDS}

Bacon stated boldly and unequivocally that he had "reserved part of his publications for a private succession." The intention to withhold and keep secret a part of the work is even stated in the title to Part lof the Instauration:

\section{BLOCK QUOTE BEGINS}

THE FIRST PART OF THE INSTAURATION, which comprises the

Divisions of the Sciences, IS WANTING [143].

\section{BLOCK QUOTE ENDS}

This part of the work was not only not to be published with the rest, but was meant to be excluded altogether, kept secret and transmitted orally. What is the nature of this oral transmission? Freemasonry, and its arcane initiation rites, can be the only explanation [144]. Bacon intended to reserve the communication of one part of his philosophy for certain appropriately chosen few. There are abundant claims that Francis Bacon created the minidramas that make up the initiation ceremonies of Freemasonry, which are based on and inspired by the Elysian mysteries. Bacon explains himself on this point beautifully in Novum Organum:

\section{BLOCK QUOTE BEGINS}

Nay, further, as it was aptly said by one of Plato's school, the sense of man resembles the sun, which openeth and revealeth the terrestrial globe, but obscureth and concealeth the celestial; so doth the sense discover natural things, but darken and shut divine. And this appeareth sufficiently in that there is no proceeding in invention of knowledge but by similitude; and God is only self-like, having nothing in common with any creature, otherwise than as a shadow and trope [145].

\section{BLOCK QUOTE ENDS}

Bacon's favorite saying was, "The glory of God is to conceal a thing; the glory of the king to search it out." He repeats this proverb again and again throughout his works. He truly saw this to be the divine 
nature of God. In the preface to the Advancement of Learning, he writes:

\section{BLOCK QUOTE BEGINS}

For the knowledge which contemplates the works of Nature, the holy Philosopher hath said expressly; that the glory of God is to conceal a thing, but the glory of the King is to find it out: as if the Divine Nature, according to the innocent and sweet play of children, which hide themselves to the end they may be found; took delight to hide his works, to the end they might be found out; and of his indulgence and goodness to mankind, had chosen the Soule of man to be his Playfellow in this game [146].

\section{BLOCK QUOTE ENDS}

He reiterates the same argument with different phrasing later in the body of the work:

\section{BLOCK QUOTE BEGINS}

For so he (King Solomon) saith expressly, The Glory of God is to conceale a thing, but the Glory of the King is to find it out. As if according to that innocent and affectionate play of children, the Divine Majesty took delight to hide his works, to the end to have them found out, and as if Kings could not obtain a greater Honour, then to be God's play-fellows in that game, especially considering the great command they have of wits and means, whereby the investigation of all things may be perfected [147].

\section{BLOCK QUOTE ENDS} Bacon writes:

In the author's preface to the Novum Organum,

\section{BLOCK QUOTE BEGINS}

Whereas of the sciences which regard nature the Holy Philosopher declares that it is the glory of God to conceal a thing, but it is the glory of the King to find it out. Even as though the Divine Nature took pleasure in the innocent and kindly sport of children playing at hide and seek, and vouched-safe of his kindness and goodness to admit the human spirit for his play fellow in that game [148].

\section{BLOCK QUOTE ENDS}

As for Bacon's Midas touch, which seems to have blessed so much that he came into contact with in his glorious lifetime, he seems even to have had a hand in the wording of Will Shakspere's epitaph on his gravestone in Stratford. The evidence for this is found in an astonishingly striking concurrence in lines appearing in Bacon's "Retired Courtier":

\section{BLOCK QUOTE BEGINS}

"Blest be the hearts that wish my Soveriegne well: Curst be the soul that thinks her any wrong! [149]"

\section{BLOCK QUOTE ENDS}

What is striking is how much these lines resemble the diction, style and reciprocal wordplay in the Epitaph found on Shakespeare's gravestone:

\section{BLOCK QUOTE BEGINS}

"Blest be the man that spares these stones,

And curst be he that moves my bones."

(Shakespeare's epitaph)

\section{BLOCK QUOTE ENDS}

There are strong reasons to believe that Francis Bacon was the one that wrote the epitaph for Will Shakspere, the Stratford frontman, in 1616, when he was laid to rest.

It has been suggested that Bacon had a secret society at his disposal, which assisted him in undertaking and accomplishing his great work [150]. The concealed and illegitimate Tudor princes, Lord Bacon and Lord Oxford, were Rosicrucians. The evidence for this is overwhelming, both for the hermeneutic wisdom and the abundant Rosicrician, emblems and symbols referenced in the writings and engravings on the frontispiece of the many works Bacon oversaw. In fact, one of the names for Bacon's secret writing ministry or guild was Fra Rosi Cross, as Alfred Dodd revealed in his seminal work Francis Bacon's Personal Life Story. The Rosicrucians referred to themselves, both in Bacon's day and more generally historically, as the Invisibles. In fact, the knights who were inducted into Francis Bacon's secret writing ministry were presented with and compelled to kiss Pallas Athena's helmet of invisibility, place it on their heads, and draw the visor down over their faces and declare themselves Invisibles. From that moment forward, they were expected to remain anonymous and to refrain from affixing their names to any literary work they might produce, though they were at liberty to employ pen names. The Rosicrucian ethos consisted of an abnegation or putting aside of all egotism, vanity or self-aggrandizement. The Shakespeare works were conceived by a learned college of men, an invisible college, and let us never forget that Francis Bacon was the founder of the Invisible College. The college was under the guidance of one or two impresarios or masters, artistic patrons who envisioned a system of dramatized philosophy, an effort to hold a mirror up to nature through dramatic art, and to pass down to posterity the hermetic science of their mystery school tradition [151].

Besides his role as the guiding light of the Rosicrucian Society, modern Freemasonry was the brainchild of Francis Bacon as well. The first authentic Lodge meeting was held at Warrington in 1646, where Lord Bacon's concept of the New Atlantis was discussed in depth. The pillars of Hercules depicted on the folio frontispiece of his work Sylva Sylvanum was 
adopted at this meeting. All those in attendance were Rosicrucian initiates, the most famous of whom was Elias Ashmole [152]. Indeed, Bacon's writings contain profound knowledge of Hermetic science, the Elysian mysteries and teachings from antiquity. The Shakespeare plays also demonstrate a knowledge of Egyptian, Persian and Chaldean lore, knowledge that is not on display in his philosophical and scientific writings [153].

The author(s) of Shakespeare are divine mimics par excellence, holding a mirror up to nature as gods of art, mimicking nature, imitating life, concealing and revealing the self in and through art just as the Divine Being both manifests and conceals the supreme personality of godhood in and through nature. Prospero, for instance, is the ideal portrait of God in relationship to the divine art. When the Bard says that he has "laid great bases for eternity," he means that he has illustrated, by means of his art, Creation itself, so as to resurrect a belief in miracles or the fact that the act of Divine Creation can be reenacted and reconstituted through artistic creation. The key to understanding the Shakespeare works is to recognize the relation of this art to its planned spiritual revelation through time [154]. This relationship becomes plain in The Winter's Tale, where the separation of this art is in the unrevealed, or in the concealment of nature, while spring and summer represents the revelation and rebirth. This is symbolized in the separation of Perdita and Hermione (Persephone and Demeter). In the winter of discontent, Hermione becomes a lifeless statue, but Perdita restores life to this art, this lifeless statue, which is reanimated, reconstituted, reinvigorated, its life restored [155].

The Winter's Tale revolves around the theme of separation and final reconciliation, or discord and separation followed by reconciliation and heavenly harmony. The exposure, loss and rediscovery of Perdita go hand-in-glove with the separation of Leontes and his wife and their ultimate reunion. The restoration of Perdita is likened to the arrival of spring, and closely followed by the discovery of the statue of Hermione and her return to life. It resembles the classical myth, in which Proserpine brings restoration to the sleeping, dormant and lifeless Earth. Of course, Hermione is not actually dead, but has been reduced to a statue, devoid of life, awaiting discovery, revelation and rebirth so that she can be transformed from a lifeless work of art into living form. The play is drawn as the poet's portrait of the revelation and rebirth that he has planned for his "philosophical play systems," of which The Winter's Tale is but one [156].

Hermione is derived from Hermonia or Harmony, who was the daughter of Mars and Venus. Mars and Venus are in constant contention as the god of war and the goddess of love, and are expressions of conflict and resolution, strife and friendship. Mars and Venus were always placed together in the ancient temples. They gave birth to order in the universe through their contention and strife. Hermione, the daughter of Venus and Mars, embodied strife and friendship to Bacon and his Rosicrucian-influenced writing guild, Fra Rosi Cross. The two principles pervading nature were represented by Mars, Venus and their daughter Hermione, as expressions of gravitation and repulsion, centripetal and centrifugal, heavy and light, dense and vacuous, etc. The eternal war of Eleusis expressed the doctrine of the conflict between spirit and matter, as two opposed principles operating within nature [157].

The poet is a god, who divides his art into internal and external aspects that are planned so that posterity can discover their truths. The unrevealed side is represented as darkness and winter, replete with icy images of death, sleep and suspended animation. The Winter's Tale depicts this creative separation under the winter and summer myth of Persephone and Demeter. Until Perdita is found, the art is in a wintry state. The rosy cross or the rose crucified, which is so central to the mysteries of Rosicrucianism, is at the heart of the great mysteries, the Elysian, Christian and even HinduBuddhist traditions. The rose crucified represents the crucifixion or martyrdom of the light, the logos, the light of the world. The red rose emerged from the blood of Adonis, the crucified sun, the martyred light, the savior's martyrdom, who will redeem through the rose that springs from his blood [158]. Adonis or Adonai was an oriental title for the Sun, and the wild boar that killed him was the symbol of winter, during which the productive powers of nature lie dormant. Venus lamented the loss of Adonis until he was reborn [159]. How fascinating in light of this boar mythology to consider that Bacon's name is the food derived from the boar or swine, while Oxford's family crest is the wild boar. Swine imagery is just one more amazing concurrence that unites the Tudor princes in life and art.

The mystical rose is the center of the Rosicrucian, Christian, Buddhist and Hindu allegorical garden. Buddha, for instance, is said to have been crucified for taking a flower from a garden. Meanwhile, the avatar of the Hindu tradition is identified with the object for which he suffered, and so he becomes a flower, rose, a padma, lotus or lily. In both the East and the West, the savior who is synonymous with the crucified and resurrected god is the rose crucified [160]. The rosy cross of the Rosicrucian Society is imbued with this symbolism as is the red rose of the Tudor family of which both Bacon and Oxford hold a princely status as the Queen's sons.

It is hardly a surprise to learn that Francis Bacon was raised in St Albans, long associated with the birth of Freemasonry in England. There are disputed dates for Freemasonry's foundation in England. Some have claimed it dates to $\mathrm{AD} 63$, while others date its foundation to the third century AD. St Albans Abbey presents with its Protomartyrs' history, the birthplace of 
Freemasonry in England. The stones of Gorhambury House, which was called "The Temple," were taken, along with the lime, from the ruins of the Abbey itself. Gorhambury House, built in 1571, the childhood home of Lord Bacon, where his imagination was first nurtured and fired, and which he retained until 1603, the year his biological mother Queen Elizabeth I, died. The house was actually constructed out of the stones which the "Hond Masons" associated with King Offa erected in memory of Saint Alban [161].

The fraternity in England maintain that Saint Alban, the proto-martyr, was responsible for bringing Freemasonry to Britain. The claim is that the brethren received their charter from King Athelstane, and that his brother Edwin summoned all the Lodges to meet at York, where the Grand Lodge of England was established, which is the paramount Masonic Lodge in the world so it is claimed [162].

In The Tempest, there is a reference to "The Widow's Son." There is an odd event described in which the Dido is ushered in as "Widow Dido." In certain ceremonies related to certain prescribed Masonic degrees, a substitution of the candidate with Hiram Abif (a representation of the architect of King Solomon's Temple) takes place. Hence, the Masons are often nicknamed "The Widow's Sons." Is there some hidden key or mystery in this that might elucidate the meaning of "Widow Dido" in this passage from The Tempest? There are many arcane ceremonies in Freemasonry such as the rite known as the "last word," and "Hiram's murder," which seems to commemorate the martyrdom of Hiram Abif, the architect of King Solomon's Temple, who, according to Freemason lore, was slaughtered by three ruffians in the Temple following his prayers. Some believe there is a significance associated with the construction of King Solomon's Temple. In the First Book of Kings it says, "And king Solomon sent and fetched Hiram out of Tyre. He was a widow's son of the tribe of Naphtali, and his father was a man of Tyre, a worker in brass ..." (KJV 1 Kings 7:13-14) Hiram, as the oldest Mason for which anything is known, is evaluated as vitally important to the Freemason Order. And since he was purportedly a widow's son, the Masons style themselves after him [163].

In the poem The Phoenix and the Turtle, there is a reference to St. John the Apostle and beloved disciple of the Christ, who lived 93 years so it is claimed. He was symbolized by the emblem of the eagle for his piercing vision into the nature of the Creator and the mysteries [164].

\section{BLOCK QUOTE BEGINS}

From this session interdict,

Every fowl of tyrant wing

Save the eagle-feathered king,

Keep the obsequy so strict.
Let the priest in Supplice white,

That defunctive music can,

Be the death divining Swan,

Lest the requiem lack his right.

(The Phoenix and the Turtle)

\section{BLOCK QUOTE ENDS}

The Templars, who were intimately connected with the Rosicrucians and Freemasons, were followers of Knights of St. John. There are further references to this connection in the same poem:

\section{BLOCK QUOTE BEGINS}

When in the chronicle of wasted time I see descriptions of the fairest wights, And beauty making beautiful old rhyme, In praise of ladies dead, and lovely knights. Then in the blazon of sweet beauty's best, Of hand, of foot, of lip, of eye, of brow, I see their antique pen would have express'd Even such a beauty as you master now. (The Phoenix and the Turtle)

\section{BLOCK QUOTE ENDS}

There is certainly implicit in the two verses a reference to a chivalric order of knights descended from antiquity.

\section{Masonic Conspiracy}

In July 1929, the foundation stone of the Shakespeare Memorial Theatre at Stratford-upon-Avon was laid according to proper Masonic ritual by Lord Ampthill-pro-Grand Master of the United Lodge of England - using an old Egyptian maul used at Saqqara 4,000 years ago, with 600 Masons present at the ceremony in full regalia. Why should the Grand Lodge of England contribute to the conspiracy to continue to foist the lie that Will Shakspere of Stratford-upon-Avon is the immortal Bard? Lord Ampthill is the person who wrote the foreword to the first biography about Gandhi written by fellow Freemason Reverend J.J. Doke. In the foreword, Ampthill denies knowing Doke. Why the need to disassociate himself from the reverend? Is it because he does not want it to be known that Doke and Gandhi are both fellow Freemasons? Gandhi studied law at one of the five Inns of Court in London known as the Inner Temple. He would not have been able to study at such a venerable English institution originally founded by the Knights Templar - the parent organization behind British Freemasonry-had he not himself been a Freemason. Gandhi's London Diary was his Freemason diary, describing his initiation through the various degrees of Freemasonry. Only 20 pages of the London Diary survive in the Collected Works of Mahatma Gandhi and describe his initiation to the $3^{\circ}$. It is interesting that Lord Ampthill had participated in the promulgation of two great Masonic historical deceptions: Shakespeare and Gandhi. In a later chapter, Gandhi's role in another major fraud perpetrated on the 
world stage by the intelligence services will be explored in great detail.

In 1723, modern Freemasonry came into the public eye with the publication of The Book of Constitutions of the Free-Masons by Dr. James Anderson under the authority and express request of the Grand Lodge of England. Before this, Speculative Freemasonry had existed in relative obscurity. Also, in the same year, Alexander Pope and Dr. Sewell published Shakespeare's Sonnets (Bedson Medley Edition), the title page headpiece of which depicted the symbols of the higher Templar and Christian degrees, which culminate in the $33^{\circ}$, the highest degree of the Order. That year was also the centenary of the publication of the First Folio of Shakespeare's plays.

By studying the Shakespeare plays, it becomes evident that the author expressed in drama the virtues a Mason is supposed to uphold. He is meant to be an ethical teacher, stressing the importance of charity at all times. The ethical philosophy is summed up in the character Berowne in Love's Labour's Lost: "For charity itself fulfills the law, and who can sever love from charity," while Portia in The Merchant of Venice expounds on this point more poetically: "The quality of mercy is not strained, it droppeth as the gentle rain from heaven upon the place beneath: it is twice blessed ..." Both speeches are examples of Freemasonic oratory and philosophy at their richest, expressing the meaning and purpose of Freemasonry as a "builder of Love [165]."

Freemasons are taught that the 'Craft' is a system of morality based on allegory and illustrated by symbolism. In the dedication to the First Folio, it is addressed to the brethren of the Masonic Order: "To the Most Noble and Incomparable Pair of Brethren William, Earle of Pembroke and Philip, Earle of Montgomery . . ." This is the customary way of addressing higher degree Freemasons. In the same dedication, Shakespeare is referred to as "so worthy a Friend and Fellow," "Fellow' referring to a "Fellow of the Brotherhood," just as the Masonic song, "For He's a Jolly Good Fellow," alludes to the very same concept of "fellow" or "brother." In fact, the $2^{\circ}$ of Freemasonry is the degree known as Fellow of the Craft, which corresponds to the master's degree in the three-tiered university degree system. Similarly, a university "Fellow" would be a "Fellow of the Craft" within the halls of learning [166].

Three pages further on in the First Folio, Ben Jonson pays tribute, "To the memory of my beloved, The Author, Mr. William Shakespeare," with beautiful but cryptic verses printed beneath the headpiece of seven Masonic Squares. '7' is the perfect Masonic number and "all squares are true and proper signs to know a Mason by," and the Square is "the sign of the Master that rules by Square."
The poem Venus and Adonis was published with the "Double A" sign on the headpiece, which was emblematic of the male and female aspects of Athena and Apollo, but also King Solomon apparently.

A Freemason is referred to several times and in sundry ways, as for instance, referring to the higher degrees, we read, "a brother of gracious Order, late came from the Sea, in special business from His Holinesse." (Measure for Measure, Act III, scene ii). In Henry $V$, the brethren are referred to as "the singing masons building roots of gold." (Henry V, 1.1). In King John, the higher degrees are referred to as "a worshipful society," but it also refers to the "Lodge" and a password suitably disguised. In Corialanus, the brethren are referred to as "apron men": "You have made good work, you and your men." The meaning of the lambskin apron being referred to in Measure for Measure becomes apparent in the satirical jest, "And furred with fox on lambskins too. To signify that craft, being richer than innocency, stands for the facing." (Measure for Measure, 3.1). This indicates that Freemasons are foxes or wolves in sheep's clothing and that the organization is not what it purports to be. Far from making "good men better" as it purports to do, it ruins good men by making them infernal. The title Measure for Measure also of course refers to "measuring" and "squaring" and "ruling," since it is about achieving balance, order and justice, i.e. measure for measure [167].

The opening lines of Julius Caesar (1.1) provide a somewhat cryptic description of the difference between an operative Mason and a Speculative Mason:

\section{BLOCK QUOTE BEGINS}

Flavius: Speak, what trade art thou?

Mar: Carpenter. Why sir, a carpenter.

Flavius: Where is thy leather apron, and thy rule? What dost thou with the best apparel on? You sir, what trade are you?

Cobbler: Truly, sir, in respect of a fine workman. I am, but, as you would say, a cobbler.

Mar: But what trade art thou? Answer me directly.

Cobbler: A trade, sir, that I hope I may use with a safe conscience; which is, indeed, sir, a mender of bad soules.

(Julius Caesar, 1.1)

\section{BLOCK QUOTE ENDS}

The early Freemasons were frequently referred to as "Sam's Sons," meaning "Solomon's Sons," and since Samson was considered a son of Solomon, it is clear that he was also considered a Mason. Samson, it should be remembered, held up the two pillars of the Temple, Joachin and Boaz, and was used as their allegorical archetype. In Love's Labour's Lost (1.2), the reference occurs when speaking of great men who have been in love. The initiate, Hercules, is offered as an 
example, but more 'authority' is requested in "men of good repute and carriage." Moth gives the approved answer, "Solomon, Master! He was a man of good carriage, great carriage for he carried the town gates on his back like a porter: and he was in love." Armado, the Master who was chastising his pupil, makes a reply in which he points out that his office is higher than Samson's, who was Porter for Tyler: "O well-knit Samson! Strong-jointed Samson! I do excel thee in my rapier as thou didst me in carrying gates. I am in love too." Armado then continues the questions, going deeper into the mysteries of Freemasonry: "Who was Samson's love, my dear Moth?" And Moth replies by recounting the allegorical myth. Armado later says, "My love is most immaculate white and red." This is a reference to the sexual mysteries of mixing semen with blood, which was a rite the Templars apparently practiced for purposes of rejuvenation.

The Porter (or Tyler) is responsible for opening the door of the Lodge when the correct password is given. A powerful tragi-comic scene in Macbeth parodies such a case, the required knocking occurring at the critical moment associated with the death of the King or Master (Macbeth, 2.3). Elsewhere, another duty of the Porter is given, as performed in the early Lodges, which consisted of marking out the floor of the Lodge with chalk. Chalk is a symbol of freedom, and the Porter used to draw the symbolic teaching of the degree on the black floor before the candidate entered. Good old Gonzalo refers to this and to the Masonic pillars: "For it is you that hath chalk'd forth the way which brought us hither . . O O, rejoice a common joy! And set it down with gold on lasting Pillars." (The Tempest, 5.1)

A mop and pail were used by the newly initiated brethren to wash the floor clean after a ceremony. Ariel, in The Tempest, subtly alludes to this and to the candidates being ship-shod when he replies to Prospero's command:

\section{BLOCK QUOTE BEGINS}

Before you can say 'come' and 'go', And breathe twice, and cry, 'so, so,' Each one, tripping on his two,

Will be here with mop and mow ...

(The Tempest, 4.1 )

\section{BLOCK QUOTE ENDS}

He concludes this with the key question to Prospero: "Do you love me, Master? No?" Prospero can only truly answer this by demonstrating it in action, which he does, setting Ariel free and then asking us, of our indulgence, to likewise set him free. In this scene, Shakespeare hints at the ultimate mystery of Freemasonry. Note that the epilogue to The Tempest is addressed to his majesty the King, which would postdate the play to after Queen Elizabeth I's death in 1603. If the truth be told, the Earl of Oxford is entreating his Royal Majesty, King James I of England, to let him return from his island prison, where he had been exiled, the penal island of Mersea.

The Tempest makes many Masonic allusions quite openly and may be the most completely Masonic play of all. Prospero is the Master, who has reached a certain degree by the beginning of the play, raising others with him. He describes himself to his daughter, Miranda, as "Prospero, Master of a full poor cell . . . Thy no greater Father." In fact, there is a cottage on Mersea Island referred to as Shakespeare's cottage fittingly enough. Is this the "poor cell" referred to, a 'cell' carrying resonances of a jail cell as well as a temple or lodge of the Order? And then there is the author of the plays represented as Prospero himself: "Prospero the prime, reputed in dignity and for the liberal arts without a parallel ... having both the key officer and office ... and all dedicated to closeness. His eyes fall fellowly drops as he learns the lessons of forgiveness and mercy, releasing by degrees, his spirit of love, Ariel [168]."

The name Prospero is of course allegorical of an initiate's name, referring to a person who makes others happy, who gives joy and prosperity to others by enabling them to prosper by the mark of the true Master Mason. He is described as a man of goodwill, beloved by his people $\left(1^{\circ}\right)$; he then faced death by drowning and starvation, brought up by his daughter with charitable care on the island on which he was marooned, a veiled reference to the Master Mason degree $\left(3^{\circ}\right)$, and ultimately overcomes potential death by clubbing Hiram Abif by means of his skill. The intended murder of Prospero was planned by three ruffians or unworthy craftsmen (the Three Juwes), who intended to kill him with blows to the head with a wooden instrument after having first stolen his books, symbolic of the secrets of the Master Mason Degree $\left(3^{\circ}\right)$. Hiram Abif, the architect of King Solomon's Temple, is ritually represented by the candidate of the Third Degree or Master Mason Degree of Freemasonry. He tries to leave the Temple through three exit points one after the other, but each is blocked by one of the three unworthy craftsmen, who are armed with architectural tools they intend to employ as weapons. The first assailant strikes the candidate representing Hiram Abif in the right temple. When the candidate attempts to leave the Temple through another exit point, his way is blocked by a second attacker who strikes him in the left temple with a plumb line. When his way through the third exit point is blocked by a third ruffian, he is struck in the middle of the forehead with a stone mason's hammer, at which point he symbolically drops down dead. The murder was to take place at noon at the entrance to Prospero's cell—noon being that time of the day when the Sun reaches the highest meridian point in the skywhich holds significance in terms of the "Killing of the King" ritual, and is featured in the $17^{\circ}$, known as the Royal Arch Degree. 
Prospero is the owner of a hat and rapier, symbols of the authority and justice of a 16th and 17th century Master, the staff being the rod or scepter of a Principal of the Royal Arch Degree, which he has to learn to 'break' and 'bury' in order to rise higher, and the book being a book of law, which he has to 'drown' in order to receive the Word of Love directly. At the end, he achieves the sublime degree and is referred to as an Oracle.

Many other Masonic allusions and mysteries are found in The Tempest as well as other plays. The mystery of the Word is significant, as in:

\section{BLOCK QUOTE BEGINS}

Ber: One word in secret . . .

Dum: Will you vouchsafe with me to change the word? Mar: Name it . . .

Long: You have a double tongue within your mask,/And would afford my speechless visor half . . . Let's part the word.

Kath: No! I'll not be your half!

Long: one word in private with you ere I die.

Kath: Bleat softly then: the butcher hears you cry.

Boyet: The tongues of mocking wenches are as keen/As the razor's edge invisible./Cutting a smaller hair than any be seen:/Above the sense of sense: so sensible/seemeth their conference ...

Ros: Not one word more . . Break off . . Break off . . . (Love's Labour's Lost, 5.2)

\section{BLOCK QUOTE ENDS}

In this mocking dialogue, the Word is provided cryptically through the use of the Capital Letter Code, beginning with the key "One Word" and continuing with the reference to the "Bleat" of the sacrificial lamb or Word of God. In addition, the Word 'BO-AS' is divided by 'CAT', which is descriptive of the mocking wench in the text and a creature associated with the Moon, the celestial object with this particular Word and Pillar of Freemasonry. In this illustration, the Word is not only 'parted,' but halved and lettered, with the author showing his mastery of its meaning and usage. Moreover, the word 'vouchsafed' is particularly familiar to the Board of Installed Masters, indicating that the Shakespearean author was a Grand Master or a former Grand Master of the Order [169].

The strongest evidence that the author's works were not under his control and had been suppressed by a secret fraternity can be found in the preface to the first edition of Troilus and Cressida in 1609, appearing five years after Oxford's official death, while the year 1609 is apparently the year of Oxford's actual death on the Isle of Mersea. The First Folio of Shakespeare's works did not appear until 1623, some 19 years after the Earl of Oxford's 'official' death and seven years after the Stratford man's death in 1616. What is evident from the Prologue to the play is that the Bard did not appear to have control over his own work. Having escaped the covetous hands of those who suppressed the other plays, Troilus and Cressida was somehow printed and distributed. The dedication is provocative because it gestures to the fact that the author and his works are intended for the highborn. It begins with the heading, "From a never writer to an ever reader. Newes." This is highly suggestive, since it points to the fact that the author may never be acknowledged, since he is "a never writer," but that his work is addressed to "an ever reader," an E. Ver reader perhaps hinted at by the cryptic heading. The author of the dedication then writes, "Eternal reader, you have here a new play, never staled with the stage, never clap-clawed with the palms of the vulgar." Does this sound like a dedication written by a commoner from Stratford? If anything, it sounds like a nobleman praising the work of another nobleman, whose newly published work has managed to escape the hands of the vulgar commoners who have failed to exhibit it at the theater. It goes on to praise the author, while never referring once to Shakespeare, the author credited with the play by posterity. The dedication further alleges that, were the names of the comedies changed to commodities.

\section{BLOCK QUOTE BEGINS}

... you should see all those grand censors that now style them such vanities flock to them for the main grace of their gravities: especially the author's comedies, that are so framed to the life, that they serve for the most common commentaries of all the actions of our lives, showing such a dexterity of wit, that those most displeased with plays are pleased with his comedies. (Troilus and Cressida, Preface).

\section{BLOCK QUOTE ENDS}

The dedication then ends with a reference to the "grand possessors," which Stratfordians - those who believe the Bard to be Will Shakspere from Stratfordupon-Avon-naïvely believe refers to an acting company that has seized control of his plays. The reason this claim is naïve is because "grand possessors" implies a body of individuals of noble rank and of considerable authority. The "grand possessors" could refer to the Freemasons or some institution under the authority of the Crown, possibly HMSS:

\section{BLOCK QUOTE BEGINS}

And believe this, that when he is gone, and his comedies out of sale, you will scramble for them, and set up a new English Inquisition. Take this for a warning, and at the pleasure of your peril's loss, for not being sullied with the smoky breath of the multitude; but thank fortune for the 'scape it hath made amongst you. Since by the grand possessors' wills I believe you should have prayed for them rather than been prayed. (Troilus and Cressida, Preface)

\section{BLOCK QUOTE ENDS}

It is clear that the plays are in the clutches of unrevealed hands, "grand possessors" as they are called. 
By "grand possessors," Stratfordians somehow have arrived at the amazing conclusion that an acting company is involved. Why the word 'grand' then? 'Grand' would hardly be a fitting word to apply to an acting company composed of common players. What is far more likely is that Sir Francis Bacon's intelligence service, Fra Rosi Cross secret literary society, or Freemasonry itself is implied.

In his seminal biography on Sir Francis Bacon, Alfred Dodd, addressing the issue of the Shakespeare manuscripts, claims that the manuscripts were filed away for safekeeping with the "grand possessors," who, according to the preface of Troilus and Cressida of 1609 kept them in safe custody for the author. The preface to Troilus and Cressida makes it abundantly clear that the plays are in the protective custody of the "grand possessors [170]." The author of the preface even suggests that Troilus and Cressida has been wrested away from the author against his wishes, bidding the reader to, ". . . thank fortune for the "scape it hath made amongst you. Since by the grand possessors' wills I believe you should have prayed for them rather than been prayed." (Troilus and Cressida, Preface) This suggests that the grand possessors exercise control over the plays and that their fate is subject to their wills. Granted, this could be with the author's approval, but the opening lines suggest that the preface is partly written to the author himself in the form of a eulogy as in the words, ". . . for it is a birth of your brain that never undertook anything comical vainly." (Troilus and Cressida, Preface) Note that the past form 'undertook' is used, implying that the products that are the birth of the author's brain are in the past. Why not 'undertake,' if in 1609 , the author is still active and writing? The reasonable explanation for this is that the author was dead by this time and his work was now in the custody of a group of individuals functioning as executors and guardians of the deceased author's manuscripts. Since Edward de Vere is believed to have officially died in 1604, this could account for why the manuscripts are no longer in the author's possession or under his control. Even if he did not die in 1604 as the official historical record maintains, but lived for some years after his apparent final curtain call, the release date of this play may still have superseded his years on this planet. Some researchers allege that the Earl did not die in 1604, but was exiled to Mersea, where he was permitted to continue his writing, but forbidden from returning to his island home, but we will come to that at the tail end of this chapter.

It was probably considered expedient by the Freemason fraternity to hold off on the release of the plays until after all the figures in the Elizabethan Court and English establishment, alluded to or lampooned in the plays, were dead. It is also probable that even an influential organization like Freemasonry could only suppress the true authorship through a generational delay, in which the release of the plays would be held up by a span of some 20 years, by such time that the true author(s), along with their political opponents, would have been forgotten. Since the hierarchy of the intelligence services is based on the initiatory degrees of Freemasonry, it is reasonable to suppose that those most highly placed in both command structures would be in many instances the same men. Therefore, it is not unreasonable to surmise that the Masons and the Elizabethan intelligence service were connected, since both Speculative Freemasonry and the British intelligence services were founded by Sir Francis Bacon and his brother Anthony, so that many of the same vanguard could be found in both fraternities.

According to a contact in the U.S.'s Office of Naval Intelligence, the overwhelming majority of higher-ranking officers in the military and intelligence command structure of the U.S. are either Freemasons or Rosicrucians. The same is the case for the British intelligence services. Since Bacon is responsible for founding Fra Rosi Cross, Speculative Freemasonry in its modern form, as well as HMSS, it is easy to assign credit where credit is due. As a fraternity wielding great influence, Freemasonry would have been able to disseminate disinformation through the education system, which would be easy to orchestrate since the university degree system is based on the first three degrees of Freemasonry-Entered Apprentice, Fellow of the Craft, and Master Mason - and could therefore control which dissertations about the Bard would obtain Ph.D.s and which would not. This means that the organization controls who gains privilege within the university establishment. The release of disinformation and the control over information are then exercised by a steering committee that functions like the Invisible College Bacon refers to in The New Atlantis, dictating what the official view on the Bard is going to be for the subsequent generations. What the preface to Troilus and Cressida appears to be saying is that the dramatist's plays are held by members of a secret fraternity of noble peerage, such as Fra Rosi Cross or the Masons and that this play was somehow rescued from their control. This poses a problem for the Baconian claim to Bacon's authorship of the plays, because, as the founder and director of the secret societies in addition to the British intelligence service, how could the plays be wrested from his control? It is an enigma and one not easy to resolve.

It is self-evident that Bacon's secret writing societies Fra Rosi Cross and The Honourable Order of the Knights of the Helmet, were extensions of the Rosicrucian and Freemason societies to which he was the Grand Master, and that these fraternal orders were behind the Stratford authorship ruse from the beginning. They needed a frontman to conceal the Invisible(s) who authored the Shakespeare works. The Stratford man was selected as the commoner frontman who would take credit for the works. This, in part, served to empower the lower classes by granting enormous dignity to a 
man from the lower ranks of society. This mission seems to have been part of Bacon's secret enterprise.

What is clear from the record is that Ben Jonson has had a hand in the publication of the First Folio of plays. This we know because of his dedication, which appears in the Folio itself. Documented proof also exists that Sir Francis Bacon had a hand in the Shakespeare plays, since the Northumberland Manuscript bears his name, along with the name William Shakespeare as well as the titles of several of the plays. In addition, there is the bi-literal cipher writings, including 13 concealed plays, embedded within many of Bacon's writings, including the pseudonymous Shakespeare plays.

As for who the custodians of the plays were, Charlton and Dorothy Ogburn have helped to identify who the "grand possessors" might have been in their classic This Star of England. In 1615, the Earl of Pembroke became the Lord Chamberlain. This makes Pembroke Lord Oxford's successor as the Lord Chamberlain of England and would put him in charge of all plays and theatrical productions staged for the monarch - in this case King James I-as it had done with Lord Oxford before him. It would therefore be with his approval that Ben Jonson would be nominated for the office of Master of the Revels. And it was at the Lord Chamberlain's behest that Jonson was awarded a pension of $£ 100$ a year. In the year 1621, Pembroke increased Jonson's annuity temporarily to $£ 200$ a year. It will be remembered that the First Folio of the Shakespeare plays came out in 1623 . We know that Jonson had a hand in the editing of the plays because his dedication to the Shakespeare works makes his contribution clear. Is it such wild speculation to suppose that he might be receiving a stipend from the Lord Chamberlain for his work on the Shakespeare manuscripts?

Not only was Ben Jonson on close terms with Lord Pembroke, he was on intimate terms with Lady Mary Pembroke as well. The "Incomparable Paire of Brethren" to whom the First Folio was dedicated, were the Countess of Pembroke's two sons, William Herbert, Earl of Pembroke, and Philip Herbert, Earl of Montgomery. Philip Herbert had married Edward de Vere's daughter, Susan. A confederacy or fraternity involving all these people had already formed when Oxford was still alive. The Ogburn's research has determined that the Countess of Pembroke, her two sons, the Earls of Pembroke and Montgomery, the Earl of Southampton-who some affirm to be Oxford's illegitimate son, Sackville-Nevill and others, all intimately connected with the Earl of Oxford, constituted the Virginia Company itself [171]. Considering that the Virginia Company was under Charter of King James I to develop the lands and resources of the colony of Virginia and whatever other territory in the New World it could lay its hands on, we can assume it was directly connected with Sir Francis Bacon's ambitions in the American colonies as outlined in The New Atlantis.

There is also ample evidence that Francis Bacon had made a substantial contribution to the plays. Baconian ciphers found in the plays as well as the Northumberland Manuscript definitely connect him to the Shakespeare plays. It is probable that, as head of British intelligence and founder of Speculative Freemasonry, and at least two secret literary societies, he would have advised his team of Good Pens on what themes, coded messages and other devices to include in the plays. As has been established, both Oxford and Bacon were illegitimate sons of Queen Elizabeth I. Bacon was also a cousin of the Cecil family and thus a filial relation of Lord Oxford through this connection as well. Bacon and Oxford would have had ample opportunity to meet and form an association in childhood, and their intimacy would have only grown during their attendance at Gray's Inn Law School, where they both purportedly wrote and produced revels for the stage. While approximately a decade younger than Oxford, Bacon wielded great influence at Gray's Inn, where many of the revels were performed, and was even installed there as dean for several years. Jonson was also closely connected with Bacon. There is ample evidence within the Jonson and Shakespeare canons to prove that Jonson and the author of the Shakespeare plays were both initiated Masons. This will be explored later in the chapter.

Jonson paid Bacon the highest tribute in 1619, giving him the title Dominus Verulamis for his persuasive power, eloquence, and graces in delivering fine speeches. According to a noted source at the time identified as Judge Webb, Bacon was closely associated with Jonson long before he was created Lord Viscount of St Albans. He even engaged Jonson to compose a masque for the Christmas celebrations in 1617. Jonson would even go on to write a panegyric on Bacon on the occasion of his 60th birthday in 1621 . What is revealing is that, though Bacon would have been intimately familiar with his family relation, Lord Oxford, he never mentions him throughout the seven volumes of the Letters and Life of Francis Bacon, except once, and that in the formal list of peers who sat as Commissioners in the trial of Essex and Southampton.

The Ogburns are correct in their estimate that Bacon and Jonson and the Freemason fraternity are responsible for orchestrating the hoax that has concealed the true authorship of the Shakespeare plays [172]. Implicating Bacon and Jonson in the greatest literary hoax in history without acknowledging Freemason complicity would be absurd, since the two men could not have acted alone and required the mobilization of a clandestine organization fully supportive of their scheme-and to which they both belonged - to successfully pull off one of the greatest 
orchestrated deceptions in world history. In commemoration of this Freemason-led deception, a Freemasonic ceremony was held in July 1929, as previously mentioned, to lay the foundation stone of the Shakespeare Memorial Theatre at Stratford-upon-Avon, a fully laid on Masonic ritual conducted by Lord Ampthill, pro-Grand Master of the United Lodge of England, in which 600 Masons were in attendance in full Masonic costume [173].

Could the Earl of Oxford, the pseudonymous author of the Shakespeare plays, have been murdered or martyred by the Masons as part of a Masonic ritual murder known as the "Killing of the King"? The sacrifice of authorship in art can be conceived as a reenactment of Jesus's martyrdom as a kind of "passion play," since it is the mystery and passion of the author's sheer obscurity that piques our curiosity and whets our appetite for discovery. It is a god-like enterprise retold in Shake-speares Sonnets over and over again, the sacrifice that is to be answered at another time, the glory that is to spring from the silence at some future date with destiny. That the world will all at once see it, and wonder why they did not see it before is an event only a breath away [174]. This explains the significance of the Freemasons using the stone maul from Saqqara to lay the foundation stone of the Shakespeare Memorial Theatre. A stone maul was used in the murder of Hiram Abif, who Freemason lore tells us was the architect of King Solomon's Temple, the Master Mason and guardian of the secrets of the Third Degree of Freemasonry. The author of the Shakespeare plays actually foretells his own end in The Tempest. The scene in which the three ruffians-Caliban, Stephano, and Trinculo - plan to set upon Prospero and steal his books is in fact a reenactment of the murder of Hiram Abif from Freemasonic lore. The modus operandi Caliban outlines is drawn directly from the legend:

\section{BLOCK QUOTE BEGINS}

Why, as I told thee, 'tis a custom with him I' th' afternoon to sleep: there thou mayst brain him Having first seized his books; or with a log Batter his skull, or paunch him with a stake, Or cut his wezand with thy knife. Remember First to possess his books; for without them He's but a sot, as I am, nor hath not One spirit to command: they all do hate him As rootedly as I. Burn but his books.

(The Tempest, 3.2.87-95)

\section{BLOCK QUOTE ENDS}

The name Prospero stands for the author and is probably to be taken as a play on the word 'prosper.' Thus, we have "Pro-Spear-O," denoting 'hope' or 'affirmation,' denoting the 'spear' of Shakespeare and the 'spear' Pallas Athena shakes at the twin serpents of ignorance and vice. At the same time, Prospero represents the Master Mason, Hiram Abif, while Caliban, Stephano, and Trinculo represent the Three
Juwes of Masonic legend-Jubila, Jubilum and Jubilo - who conspired to steal the secrets of the Master Mason Degree from Hiram Abif, at the Temple. The account of the fate that attended Hiram Abif at the Temple is given in the Masonic Rite of the Third Degree:

\section{BLOCK QUOTE BEGINS}

His devotions being ended, he prepared to retire by the south gate, where he was accosted by the first of these ruffians, who, for want of a better weapon, had armed himself with a plumb rule, and in a threatening manner demanded of our Master . . . the genuine secrets of Osiris, warning him that death would be the consequence of his refusal; but true to his obligation he replied that those secrets were known to but three in the world and that without the consent of the other two, he neither could, nor would divulge them ...

This answer not proving satisfactory, the Ruffian aimed a violent blow at out Master's forehead, but startled by the firmness of his demeanour, it only glanced down the right temple. Yet with sufficient force to cause him to reel and sink to the ground on his left knee.

Recovering himself from this situation, he rushed to the west gate where he stood opposed by the second ruffian, to whom he replied as before, yet with undiminished firmness when the ruffian, who was armed with a level struck a violent blow on the left temple which brought him to the ground on his right knee.

Finding all chances of escape in both these quarters cut off, our Master staggered, faint and bleeding, to the east gate where the third ruffian was posted and who, on receiving a similar reply to his insolent demand ... struck him a violent blow full in the center of the forehead with a heavy stone maul, which laid him lifeless at his feet [175].

\section{BLOCK QUOTE ENDS}

The intended murder of Prospero is planned by three ruffians, representing the Three Juwes of Masonic lore, who intended to kill him with a blow to the head from a stone hammer, representing the maul of Masonic legend. The mischief they intend is to follow the stealing of Prospero's books, which are symbolic of the secrets of the Master Mason. The murder was to take place at noon at the entrance to Prospero's cell, the cell representing the Masonic Temple. The time of noonday is significant as it is the highpoint of the Sun, which is of great ritual significance in the "Killing of the King" rites, associated with Osiris the king, the Sun-god, and Horus, the son of the Sun god [176]. 
If the man posterity knows as Shakespeare was subject to a political assassination, would it not account for the disparate accounts concerning the cause of death in the case of Lord Oxford and the absence of a proper burial site for so great a personage? For instance, was he buried in the churchyard of the chapel in the village of Hackney or in Westminster Abbey? The historical record is uncertain on this point. Would it not also provide an additional motive for concealing the true authorship of the greatest literary personality in history? If someone was vindictive enough to kill him, then surely they would gain greater revenge from denying him his literary claim to fame. Would not such a revelation be shaking a spear at the serpent of vice in the form of the British establishment itself?

\section{Masonic and Rosicrucian Themes in Shakespeare}

There is ample evidence that the plays contain Hermetic and Ancient Mystery sources of Rosicrucian and Masonic origin. The Sonnets are pregnant with fertility god imagery of rebirth and revelation [177]. References to Freemasonry abound in the Shakespeare plays. This is no surprise since the author is an initiate of Bacon's Speculative Freemason fraternity and Bacon is responsible for founding all 33 degrees of Freemasonry, mini-dramas in themselves, the Third Degree on which the plot of The Tempest is based being but one. Just to prove the case that the plays were written by a high initiate of Freemasonry, a list of references is here made that the reader may judge for himself. There is a reference to Masonic apparel, accessories and symbols in The Merry Wives of Windsor consisting of the garter, and the compass in a ring. The garter is worn by Masons, while a square and compass are featured in a Masonic ring worn on the finger. There is a reference to a young Masonic initiate in Much Ado About Nothing: "Is there no young squarer that will make a voyage with him to the devil?" (Much Ado About Nothing, 1.2.69, 70) There is a reference to a candidate being initiated into the rites of the Third Degree in The Tempest with the following expressions employed by Caliban over the course of Act 4: "Be patient ... I'll bring thee . . . Hoodwink this . . . speak softly ... This is the Mouth of THE CELL . . . No more ... ENTER." There is an allusion to the Worshipful Master in The Taming of the Shrew: "What! My old Worshipful Master." (The Taming of the Shrew, 5.1.55) Then there is the Masonic ritual letter code referred to in Richard III: "And from the Cross Row plucks the letter G." The Cross Row refers to the Rosy Cross of the Rosicrucians also known to Masons, and the letter ' $G$ '- -so sacred to Masons-refers to the Grand Geometrician or God, who is responsible for all sacred geometry, Temple design and architecture [178].

From the evidence provided in the preface to Troilus and Cressida, we already know that "grand possessors" have dispossessed the author of his books. Are these the ruffians he refers to in The Tempest? We should note that the author's primary concern in The
Tempest is the issue of dispossession. Many scholars are in agreement that The Tempest is the last of the author's plays. Not only does the author break his wand at the end of the play, but he sets the nature spirit that has been his muse, Ariel, free [179]. Does this not signify that the master Prospero has hung up his hat? There is no question that he sees his artistic days as being at an end, Prospero's epilogue seeming more like his final curtain call and find farewell:

\section{BLOCK QUOTE BEGINS}

Now my charms are all o'erthrown, And what strength I have's mine own, Which is most faint: now, 'tis true, I must be here confined by you, Or sent to Naples. Let me not, Since I have my dukedom got, And pardon'd the deceiver, dwell In this bare island by your spell . . . (The Tempest, Epilogue)

\section{BLOCK QUOTE ENDS}

First, the author addresses his waning artistic powers, which are nearly eclipsed. Then Prospero says, in what appears to be the author's final address to the King - only fitting since the play is probably being staged for King James I- "now, ' $t$ is true,/I must be here confined by you,/Or sent to Naples." The choice had probably already been given to Oxford by King James, while he was temporarily incarcerated and held in the Tower of London, along with Oxford's alleged son, the Earl of Southampton, either to be confined to the penal island of Mersea or sent into exile, perhaps to Naples, Italy, where he is known to have cottaged in his younger days. He then entreats the King not to exile him, since he has recovered his dukedom. This corresponds to Oxford receiving back some of the landholdings the Queen had earlier confiscated and awarded to Earl of Leicester and others as patronage favors. He then indicates that it is under the King's curse or "spell" that he is able to continue living on this bare island - that island possibly being the Isle of Mersea, where Oxford is rumored to have been sent into exile - a penal island surrounded by a poison bog that offered no avenue of escape. He then goes on to appeal to the King for clemency and freedom:

\section{BLOCK QUOTE BEGINS}

But release me from your bands

With the help of your good hands:

Gentle breath of yours my sails

Must fill, or else my project fails,

Which was to please.

(The Tempest, Epilogue)

\section{BLOCK QUOTE ENDS}

In the above lines, Oxford seems to be appealing to the King for forgiveness, hoping that, if his play pleases, the King might see fit to release him from confinement on the island and fill his sails with his 
command that he might return to England, since the entire play was conceived to please the King and win his approval. He then complains of the despair he is experiencing that only prayer can deliver him from. He then appeals to the King to act according to the Golden Rule, forgiving him his trespasses, as he has forgiven those who have trespassed against him, seeing as he is "more sinned against than sinner":

\section{BLOCK QUOTE BEGINS}

And my ending is despair, Unless I be relieved by prayer, Which pierces so, that it assaults Mercy itself, and frees all faults. As you from crimes would pardon'd be, Let your indulgence set me free.

(The Tempest, Epilogue)

\section{BLOCK QUOTE ENDS}

Oxford concludes by appealing to the King to free him at his pleasure. Now compare Prospero's epilogue with a story pertaining to Lord Oxford related by Peter Sammartino in The Man Who Was William Shakespeare. The story goes that King James I was suspicious of Oxford because of the loyalty he had demonstrated to the protestant Queen Elizabeth, who he knew full well was Oxford's mother. James I would have been suspicious of Oxford's acceptance of a Scottish Stuart king being on the throne. He would have been reluctant to assassinate or execute Oxford, however, as he probably feared rebellion. He resolved instead on confining Oxford to the Tower of London. It was at this time that Oxford's son-in-law, the Earl of Derby, suggested a compromise to King James I. Since Oxford was the principle writer in all England, he should be permitted to live. Derby proposed that he be removed from the public arena so that he no longer posed a threat to the King. The King then gave Oxford a choice: oblivion or death. Oxford naturally would have chosen oblivion. This would have eliminated him as a political threat, for without the Earl in Court wielding his pen, no one could have discerned the message he imparted through the lines of his plays. It was at this time that he was pronounced officially dead, in 1604. Oxford was then allegedly sent to the Isle of Mersea, a penal island off the coast of Essex County near Colchester, where he was exiled by King James I. There he is said to have spent the rest of his life in isolation attended to by only one servant who brought him logs for the fire as well as food and water, another striking parallel to The Tempest, as Caliban is employed in the same daily tasks as the servant of Prospero. Oxford is said to have continued writing and revising his plays until the year of his actual death, which was apparently 1609 [180]. What is interesting about this story is that it seems to corroborate with Prospero's account of events in The Tempest's epilogue and is therefore worth including in the chapter as a footnote.
What happened at the hour of Oxford's official death in 1604 is highly suspicious. The events have been recorded in G.P.V. Akrigg's Shakespeare and the Earl of Southampton. The events are of so extraordinary a nature that it raises suspicions about the allegation that Southampton, the 'Fair Youth' referred to in the Sonnets, was in fact the illegitimate child of Oxford and a claimant to the throne. In fact, Oxfordian scholar Paul Streitz has proposed that Edward de Vere was actually Edward-Tudor-Seymour, the illegitimate son of Queen Elizabeth I, conceived through an illicit affair between 15-year-old Princess Elizabeth and her stepfather Thomas Seymour [181]. The reason events of that day seem to confirm this is that Southampton was arrested on June 24, 1604, the day of Oxford's 'official' death, when a seeming panic erupted in King James's Court. What this suggests is that the Earl of Southampton may have been perceived as a threat due to the fact that he himself may have been a claimant to the throne. The King may have been concerned that, with Southampton's father Oxford removed from the political landscape, Southampton may have developed a lust for the throne himself. The King immediately ordered Southampton to confine himself to chambers and called upon the protection of his loyal Scots guards. Southampton and other associates of the Earl of Oxford were arrested and taken to the Tower for questioning. Their personal papers and documents were also seized and examined, presumably for evidence of treasonous plotting. The very next day they were released on their own recognizance. Despite the uproar over the incident, the authorities loyal to the King kept silent, no official explanation ever being offered, while details pertaining to the incident were suppressed. This finding was reported by Oxfordian Randall Barron to The Shakespeare Oxford Newsletter put out by the Shakespeare Oxford Society in the Fall, 1993 edition. Barron's conclusion is that, among the papers and documents that were probably seized on the occasion would be Oxford's own, since they were probably perceived as a national security threat [182].

The register of the Church of St. Augustine in Hackney tells us that Oxford died of the plague: "Edward de Vere, Erle of Oxenford, was buried the 6th day of July, anno 1604." In the margin of the same page in the church register is the annotation "The plague." He is supposed to have been interred there, yet no grave marker has ever been found. The Tudor church was destroyed in 1798, and the ancient gravestones, defaced by time, have been stacked against the church wall [183]. The chances of ever finding evidence of Oxford's interment at Hackney parish church are exceedingly low. Regarding the earl's interment, Lady Oxford's last will and testament attests to the fact that her husband was buried in the churchyard of Hackney parish church, as she stipulated in the passage from her will and testament below that she wished to be laid there with her husband: 


\section{BLOCK QUOTE BEGINS}

... in the Church of Hackney, within the county Middlesex, as near unto the body of my late dear and noble lord and husband as may be; only I will that there be in the said Church erected for us a tomb fitting our degree [184].

\section{BLOCK QUOTE ENDS}

Yet, directly contradicting this is the testimony of Oxford's first cousin, Arthur Golding's son, who wrote of Oxford's interment: "I will only speak what all men's voices confirm: he was a man in mind and body absolutely accomplished with honorable endowments; he died at his house in Hackney in the month of June Anno 1604 and lieth buried at Westminster [185]." Some researchers have accounted for this with the explanation that the earl's body was at some point exhumed for reburial at Westminster Abbey. After he purportedly died of the plague? How absurd. The authorities would never approve the exhumation, transport and re-interment of a corpse of someone purported to have died of a deadly and contagious pathogen.

When he allegedly died of the plague in 1604, and was purportedly buried in the churchyard at Hackney parish church, there was no memorial and he left no will. Is it not strange that one of the most legendary nobles in English history should receive no tribute and leave no will? [186]. This suggests that he died in disgrace or that his death deliberately received as little attention as possible. Can one conclude otherwise than that the circumstances of his life and death were being deliberately suppressed? Even the stories related to his death are inconsistent. There is even a rumor that he survived beyond his official death in 1604 to live for an additional five to seven years in exile on the Isle of Mersea. True, this story might be of the same category as those that attend the lives of larger-than-life figures such as Christopher Marlowe, Wolfgang Amadeus Mozart, Edgar Allen Poe, or more recent personages such as Jim Morrison, James Paul McCartney, Elvis Presley, and Michael Jackson, all of whom have had mysterious circumstances attached to their apparent deaths, but could it just be that the very mystery surrounding their deaths is due to something macabre and untoward attending their death knell? Could the riddle of de Vere's death point to a yet unsolved homicide?

There are haunting examples of foreshadowing in the Shakespeare plays, in which the author seems to prophecy his own death and interment. While such references abound, this chapter will examine two in which the characters in question have both been convincingly linked to the author of the plays, they being Henry $V$ and Romeo and Juliet. In Henry $V$, for instance, the king is haunted by the fear that he will be left without a tomb or grave, in which he sees it as his curse to be punished by not receiving a proper Christian burial should he fail in his campaigns in France:

\section{BLOCK QUOTE BEGINS}

Or there we'll sit,

Ruling, in large and ample empery,

O'er France, and all her almost kingly dukedoms,

Or lay these bones in an unworthy urn,

Tombless, with no remembrance over them:

Either our history shall, with full mouth,

Speak freely of our acts; or else our grave,

Like Turkish mute, shall have a tongueless mouth,

Not worshipped with a waxen epitaph.

(Henry V, I.2.233-241)

\section{BLOCK QUOTE ENDS}

Square the above passage with the problem attending the mystery over Oxford's interment. Where exactly is one of the greatest noblemen in England's history buried or is he buried at all? Was it perhaps a Masonic punishment for those who betrayed the Order not to receive a proper burial, and was that the fate he met with, a prophecy that was eventually fulfilled? There is evidence to support just such a speculation. The evidence is contained in the First Degree ritual oath of Freemasonry:

\section{BLOCK QUOTE BEGINS}

I . . . of my own free will and accord, in the presence of Almighty God and this worshipful lodge . . . do hereby and hereon most solemnly and sincerely promise and swear, that I will always . . . conceal and never reveal any of the secrets, arts, parts, or points of the hidden mysteries of Freemasonry ... to any person or persons whomsoever ... except it be to a . . . brother Mason or in a lodge of Masons . . . binding myself under no less penalty than that of having my throat cut from ear to ear, my tongue torn out by its roots, my body buried in the sands of the sea at low water mark where the tide ebbs and flows twice in twenty-four hours, should I ever willingly or knowingly violate this my solemn oath of an Entered Apprentice Mason, so help me God and keep me steadfast [187].

\section{BLOCK QUOTE ENDS}

Implied in this oath is the assurance that the candidate who reveals the secrets of Freemasonry will be denied a Christian burial and will be assigned to the waters where the tide comes in and out twice a day. Oxford probably met with such a fate on the Isle of Mersea, where he was exiled and that the punishment was meted out very likely because of the secrets revealed in the last play he ever wrote, The Tempest, which constituted his last desperate appeal to the King to allow him to return from his island prison.

As for the speculation that the earl may have been murdered by the Masons or indeed by King James I's henchmen - a fate he seems to fear and point to in play after play-we have the bone-chilling presentiment 
of Romeo preceding the mask, in which in an aside to the audience, he prophesies his own death:

\section{BLOCK QUOTE BEGINS}

I fear, too early; for my mind misgives

Some consequence yet hanging in the stars

Shall bitterly begin his fearful date

With this night's revels and expire the term

Of a despised life, closed in my breast,

By some vile forfeit of untimely death.

(Romeo and Juliet, 1.4.104-111)

\section{BLOCK QUOTE ENDS}

The fact that the prophecy is uttered as an aside to the audience indicates that its relevance is not so much related to Romeo's imminent appearance at the ball, but is in fact meant to be taken in a context outside the play, as an aside. As is so often the case in Shakespeare, Romeo's speech is a deliberate double entendre. While Romeo prophesied that some dark fate will begin to work its poison that night at the masque ball-which will end in his untimely death-so the author also had a predilection about his own death, the reference to "this night's revels" as much applying to the author's opening night at the theater as to the ball Romeo plans to attend, in which his highly charged 'political' play The Tragedy of Romeo and Juliet will be staged for the first time. The implication is that the dark fate of untimely death and political assassination will begin its slow advance that night at the theater. The play Romeo and Juliet was most assuredly political in import. For those unversed in the background to the play, Oxford was imprisoned for a brief period for his affair with Anne Vavasor, one of the Queen's handmaidens. Anne's uncle, Thomas Knyvet, challenged Oxford to a duel, which left them both wounded. Street battles between the Vavasor clan and Oxford and his acting troupe from Blackfriars Theatre took place over several months, providing the inspiration for the Montagues and the Capulets [188]. Oxford appears to have taken revenge in the balcony scene of Romeo and Juliet by having at the Queen:

\section{BLOCK QUOTE BEGINS}

But soft! What light from yonder window breaks?

It is the East and Juliet is the sun!

Arise, fair sun, and kill the envious Moon,

Who is already sick with grief

That thou her maid art far more fair than she,

Be not her maid, since she is envious.

Her vestal livery is but sick and green,

And none but fools do wear it. Cast it off.

(Romeo and Juliet, 2.2.1-9)

\section{BLOCK QUOTE ENDS}

The references here are unmistakable. The Queen was often referred to by the appellations Diana, Virginia, or Cynthia denoting the Moon goddess. The Tudor livery worn by all servants to the Queen was green and white [189]. There is no mistaking the fact that Juliet is here being referred to as the Queen's maidservant. In Romeo's speech, the Queen and his lover Anne Vavasor, the Queen's maidservant, are both implied. The speech is undeniably to be taken as a snub at the Queen's vanity in probable revenge, on RomeoOxford's part, for the wounds of love caused him by the fair Rosaline, a character in which the Queen is also implied, as in the Tudor rose royal line. This provides one more reason for the necessity of a pen name. Having been made to look foolish to her Court by Oxford's portrayal of her in his play, she can hardly turn around and punish him for the offense, since she would only make more of a spectacle of herself. She is therefore compelled to pocket the insult. As a consequence of his shift from Continental targets to targets closer to home, Oxford would of course have placed himself in far graver political danger. This latter fact accounts for the forlornness of Romeo's prophecy.

On the occasion of Oxford's 'official' death in 1604 , he apparently left no will and testament. It is impossible to fathom why a man of his importance would have no concern for what became of his personal property and effects following his death [190]. It is claimed that Oxford, probably in weakened health, succumbed to the plague. This claim is highly suspect. Breakouts of the plague usually occurred in London in the summer as the result of drinking water being contaminated by human and animal waste. The poet lived well north of the city in Hackney, where vulnerability to the plague would have been exceptional. Deaths resulting from the plague among the aristocracy were extremely rare. Motives for murder or exile of a potential heir to the throne would be strong. And there is ample evidence that Oxford was the Queen's son, the strongest of which is the signature Oxford used to sign all his personal letters up to the time of King James's succession. The signature consisted of an overarching crown above his name and seven slash marks beneath. Had he succeeded Elizabeth on the throne of England, he would have been Edward VII. This practice of adorning his signature with a crown and seven slashes ceased following the Queen's death and burial. Oxford's Tudor signature appears in a letter to Robert Cecil dated April 25, 1603. Queen Elizabeth was interred at Westminster on April 28, 1603. In a letter to Robert Cecil following her burial, Oxford suddenly drops the practice. No other signatures extant following that date contain the marks denoting his divine right to Tudor succession because he would not be King. 


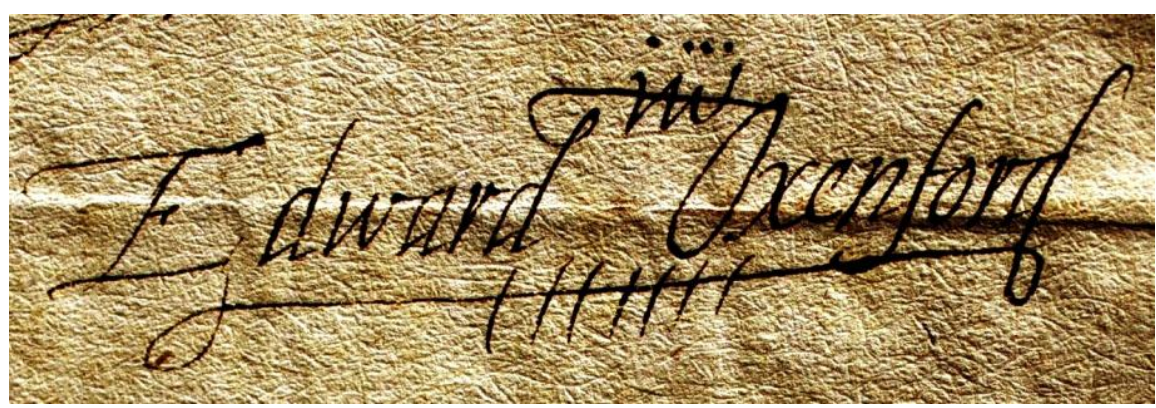

There is considerable circumstantial evidence that Oxford may have been murdered or exiled. It is interesting to note that his 'official' death or disappearance occurred only a year after the Queen's death. Without the protection of the Tudor Queen, he may have found himself in an increasingly vulnerable position politically and socially. In addition, the Shakespeare canon provides strong evidence the author is the Queen's son. As discovered by Alfred Dodd, the author's sonnet-diary appears to contain an appeal to the Queen to acknowledge the author as her son and his right to succeed her, though Dodd credits the other concealed Tudor prince, Francis Bacon, as the author. The appeal could not be more pointed in Sonnet 13: "You had a father; let your son say so." (13.14) Or the warning given in Sonnet 14 more explicit: "Or else of thee this I prognosticate,/Thy end is truth's and beauty's doom and date." (14.13-14) Given that Elizabeth I was famed for her beauty and given that Oxford was officially of the line of de Vere or the House of Vere, the words 'truth' and 'beauty' appear to refer to their respective lines of heredity as Queen and son, since the name 'Vere' means 'truth' in Latin. Further evidence for the author's link to the Tudor line can be found in the oft quoted line by Juliet:

\section{BLOCK QUOTE BEGINS}

What's in a name? That which we call a rose

By any other name would smell as sweet.

So Romeo would, were he not Romeo called,

Retain the dear perfection which he owes

Without that title.

(Romeo and Juliet, 2.2. 43-47)

\section{BLOCK QUOTE ENDS}

The reference to the 'rose' is a veiled reference to the Tudor rose. Thus, the Bard's lineage would have the same pedigree whether or not the Tudor princes, Bacon and Oxford, bore the name associated with the Tudor line. Their pedigree would therefore remain sweet scented no matter what name they bore. The princes are of the sweet Tudor rose lineage whatever name they go by. The princes will thus retain the peerage and perfection of their birth even without the title associated with the Tudor royal bloodline, the Rosy Cross.

As for Tudor prince, Francis Bacon, he died on April 9, 1626 in the early morning of Easter Sunday, three years after the publication of the Shakespeare Folio of 1623. He was sixty-six years old. He died in the Earl of Arundel's house in Highgate, near London, where he was taken after catching a bad chill, which developed into pneumonia [191]. Lord Bacon's death was the direct result of the cold experiments he was conducting, in which he was attempting to preserve meat through the use of snow. He was out taking the air in a coach and four with Dr. Witherborne, a Scotchman of his acquaintance, and Physician to the King. They were riding toward Highgate, with snow on the ground. It suddenly occurred to him that flesh could be as effectively preserved in snow as in salt.

Bacon and the good doctor, being men of science, decided to proceed with the experiment. They alighted from the coach, and proceeded up to the door of an old woman's humble cottage at the bottom of Highgate hill. There, they procured a hen and paid her for it. They urged the hen woman to exenterate it, after which they stuffed the bird with snow. Lord Bacon helped with this procedure. Unexpectedly, the show so chilled his Lordship that he immediately fell deathly ill, so ill that he could not find the energy to return to his own lodgings at Gray's Inn. Instead, he was taken to the Earl of Arendale's house at Highgate, where they put him into a bed warmed by the servants with a bed pan. However, the bed was damp due to the fact that it had not been slept in for two years, causing the cold to go into his lungs, and within three days he was dead from suffocation [192].

\section{REFERENCES}

1. Rolland DeVere, A Student's Guide to the Shakespeare Mystery. Hunting Valley, $\mathrm{OH}$ : The U of School P, 1993, 12, 13.

2. Wigston, W. F. C., Bacon, Shakespeare and the Rosicrucians. London: Geaorde Redway, 1888,pp.244, 245. Charlton Ogburn, The Mysterious William Shakespeare, p.215.

3. Charlton Ogburn, The Mysterious William Shakespeare, p.215.

4. Ibid.

5. Leonard Digges, "Introduction to First Folio," quoted in MWS, p.235.

6. Edwin Durning-Lawrence, Bacon Is Shakespeare, New York: The John McBride Co., 1910, p.125.

7. Ibid., p.126.

8. Ben Jonson, on the Portrait of Shakespeare, from $M r$. William Shakespeare's Comedies, Histories, and 
Tragedies (1623), "To the Reader," as quoted in MWS, p.224.

9. Ibid.

10. Ben Jonson, on the Portrait of Shakespeare, from $M r$. William Shakespeare's Comedies, Histories, and Tragedies (1623), "To the Reader," as quoted in The Mysterious William Shakespeare, p.225.

11. Charlton Ogburn, The Mysterious William Shakespeare, pp.236. 237.

12. Elizabeth Gallup, The Bi-literal Cipher of Francis Bacon, p.198.

13. Ben Jonson, To the Memory of my Beloved, the Author, Mr. William Shakespeare (1623), quoted in The Mysterious William Shakespeare, p.237.

14. Ben Jonson, Eulogy in the First Folio, 1610, quoted in The Mysterious William Shakespeare, p.237.

15. Charlton Ogburn, The Mysterious William Shakespeare, p.238.

16. Paul Streitz, Oxford: Son of Queen Elizabeth I. Darien, CT, USA: Oxford Institute Press, 2001, pp.24.

17. Ibid., p.8.

18. Ibid., p.11.

19. Ibid.

20. Charlton Ogburn Jr. The Mysterious William Shakespeare: The Myth and the Reality.McCeal, VA: EPM Publications, Inc., 98.

21. Charlton Ogburn Jr., The Mysterious William Shakespeare, p. 26

22. Ibid., p,97.

23. Ibid., p.234.

24. Peter Sammartino, The Man Who Was William Shakespeare. New York: Cornwall Books, 1990, 52.

25. Ibid., p. 90.

26. Alfred Dodd, Francis Bacon's Personal Life-Story: The Age of Elizabeth (Vol. 1). Rider \& Co., 1949, 131.

27. Charlton Ogburn Jr., The Mysterious Wm. S., 747.

28. Peter Sammartino, The Man Who Was William Shakespeare, 60.

29. Alfred Dodd, Francis Bacon's Personal Life Story: The Age of Elizabeth (Vol.1), p.137.

30. William T. Smedley, The Mystery of Sir Francis Bacon, Mila, MT: Kessinger Publishing, Reprint, Originally Published in 1910, 102.

31. Anonymous poem attributed to John Lyly quoted in Charlton Ogburn Jr.'s The Mysterious Wm. S., 705.

32. John Davies's poem quoted in Charlton Ogburn Jr.'s The Mysterious Wm. S., 104.

33. Richard F. Whalen, Shakespeare: Who Was He? The Oxford Challenge to the Bard of Avon, Westport CT: Praeger Publishers, 1994, 26, 27.

34. The Queen's Privy Seal Warrant quoted in Charlton Ogburn Jr., The Mysterious Wm. S., 688.

35. Charlton Ogburn Jr., The Mysterious Wm. S., 688, 689.

36. Thomas Heywood's Apology for Actors quoted in Dorothy and Charlton Ogburn Sr., This Star of England. New York: Coward McCann, Inc., 1852, 710.

37. Charlton Ogburn Jr., The Mysterious William Shakespeare, 694.
38. Venetian Ambassador of Spain's Report to Philip II quoted in Charlton Ogburn Jr.'s The Mysterious Wm. S., 692 .

39. Dorothy and Charlton Ogburn Sr., This Star of England, 711.

40. Charltton Ogburn Jr., The Mysterious Wm. S., p.694.

41. Alfred Dodd, Francis Bacon's Personal Life Story: The Age of Elizabeth (Vol.1), p.130.

42. Charlton Ogburn Jr., The Mysterious Wm. S., 694, 695.

43. Elizabeth Gallup. The Bi-literal Cipher of Francis Bacon, p.26.

44. Oleg Seletsky, Tiger Huang and William HendersonFrost, "Shakespeare Algorithm Study," Dartmouth College, Dec. 12, 2007, http://www.cs.dartmouth.edu/ datamining/Final.pdf

45. Ibid., p.96.

46. Ibid., p.107.

47. Ibid., p.107, 108.

48. Thomas Nash, 1589, quoted in Francis Bacon Our Shake-speare, Creative Media Partners, LLC, 2019 , p.67.

49. Edwin Reed. Francis Bacon Our Shake-speare, p.108.

50. Elizabeth Gallup, Francis Bacon's Bi-literal Cipher, Part II, p.15.

51. Excerpt from The Book of Sir Thomas More from Andrew Dickson and British Library curators, https://www.bl.uk/collection-items/shakespeareshandwriting-in-the-book-of-sir-thomas-more

52. Andrew Dickson and British Library curators, https://www.bl.uk/collection-items/shakespeareshandwriting-in-the-book-of-sir-thomas-more

53. Label written by Andrew Dickson and British Library curators, https://www.bl.uk/collectionitems/shakespeares-handwriting-in-the-book-of-sirthomas-more

54. https://www.art.com/products/p22114034530-sai7641351/handwriting-and-signature-of-sir-francisbacon-from-a-letter-to-king-james-april-29-1615.htm

55. Edwin Reed, Francis Bacon Our Shake-speare, p.116.

56. Ibid., p.117.

57. Excerpt from Francis Bacon's Will quoted in Francis Bacon Our Shake-spear, p.120.

58. Ibid., p.120.

59. Ignatius Donnelly, Great Crytpogram: Francis Bacon's Cipher in the So-called Shakepeare Plays, (Vol. 1 \&2), R.S. Peale \& Company, 1887, p, 713, 714.

60. Ibid., 710-713.

61. Ibid., 724-726.

62. Ibid., $718,719$.

63. Ibid., 721, 722 .

64. Ibid., 723, 724.

65. "Love's Labour's Lost," Shakespeare Folio 1623, quoted in "Bacon is Shake-speare" by Edwin Durning-Lawrence, p.136.

66. Bacon's Latin hexagram on page 136 of Shakespeare's Folio, quoted in Bacon is Shakespeare, p.93.

67. Edwin During-Lawrence, Bacon Is Shake-speare, p.98.

68. Ibid., pp.100, 101

69. Ibid., p.101. 
70. Ibid., pp.103, 104.

71. Alfred Dodd, Francis Bacon's Personal Life-Story: The Age of Elizabeth (Vol. 1), 156.

72. Richard F. Whalen, Shakespeare: Who Was He? The Oxford Challenge to the Bard of Avon, Westport CT: Praeger Publishers, 1994, pp.154, 155.

73. William T. Smedley, The Mystery of Sir Francis Bacon, p.98.

74. Ibid.

75. Peter Sammartino, The Man Who Was William Shakespeare, pp.88, 89.

76. John Mitchel. Who Wrote Shakespeare? London: Thames and Hudson, 1996, p.161.

77. Peter Sammartino, The Man Who Was William Shakespeare, p.90.

78. Ibid., p.89.

79. Charlton Ogburn Jr., The Mysterious Wm. S., 291, 292.

80. Edward de Vere, "Labour and Its Reward" in The Poems of Edward de Vere, http://www.shakespeareoxford.com/poemslny.htm

81. Ibid.

82. Alfred Dodd, Francis Bacon's Personal Life-Story: The Age of Elizabeth (Vol.1), pp.80, 81.

83. Paul Streitz, pp.83, 84.

84. Elizabeth Gallup, The Bi-literal Cipher of Francis Bacon, 89-90.

85. Ibid., p.369.

86. Sammartino, Peter. The Man Who Was William Shakespeare. London: Cornwall Books, 1990, p.49.

87. Lord Burghley, Certaine Preceptes, quoted in The Mysterious William Shakespeare, p.370.

88. Charlton Ogburn, The Mysterious William Shakespeare, p.397.

89. Ibid., p.416.

90. Giles Fletcher, writing in Latin of Oxford's horsemanship and translated into English, quoted in The Mysterious William Shakespeare, p.479.

91. Francis Walsingham in a Letter dated March 23, referenced in The Mysterious William Shakespeare, p.646.

92. Edward de Vere, ("Echo Verses," Poems of Edward de Vere, Shakespeare Oxford Fellowship. http://shakespeareoxfordfellowship.org/poems-ofedward-de-vere/

93. Charlton Ogburn, The Mysterious William Shakespeare, p.650.

94. Letter written March 17, 1582 by Antony Bacon, quoted in The Mysterious William Shakespeare, p.650.

95. Charlton Ogburn, The Mysterious William Shakespeare, p, 650.

96. Roger Townsend, chronicler of the Blackfriars Theatre feud, referenced in The Mysterious William Shakespeare, p.65.

97. Charlton Ogburn, The Mysterious William Shakespeare, p.652.

98. Ibid.

99. Ibid., p.653.

100. Ibid., p.655.

101. Ibid., p.655, Footnote 3 .

102. Charlton Ogburn, The Mysterious William Shakespeare, p.656.
103. Richard Masters, "Letter to Burghley, 7th March, 1574," quoted in The Mysterious William Shakespeare, p.562.

104. Lord Burghley, Diary Note written January 3, 1576, referenced in The Mysterious William Shakespeare, p.562.

105. Charlton Ogburn, The Mysterious William Shakespeare, p.563.

106. Ibid., p.563.

107. Ibid., p.565.

108. Friedrich Nietzsche, Prologue to Thus Spoke Zarathustra, Trans. R.J. Hollingdale, Penguin Random House, 1961, p.3.

109. Morant and Wright, "The Histories of Essex," referenced in The Mysterious William Shakespeare, p.575.

110. Charles B. Barrel, Traditional Memoirs of the Reigns of Elizabeth and James I, referenced in The Mysterious William Shakespeare, p.576.

111. Stow's eyewitness account of naval battle with Spanish Armada, quoted in The Mysterious William Shakespeare, p.705.

112. Camden's eyewitness report on naval battle with Spanish Armada, quoted in The Mysterious William Shakespeare, p.705.

113. Poem attributed to John Lily in The Mysterious William Shakespeare, p.705

114. Report of naval battle with Spanish Armada sent to English Government in The Mysterious William Shakespeare, p.707.

115. The English Admiral reporting on naval battle with Spanish Armada in The Mysterious William Shakespeare, $\mathrm{p}, 707$.

116. Lucy Aikin's account of Queen's inspection of the troops in The Mysterious William Shakespeare, p.707.

117. Charlton Ogburn, The Mysterious William Shakespeare, 704-708.

118. Ibid., p.315.

119. Charlton Ogburn, The Mysterious William Shakespeare, pp.601, 602.

120. Lord. Oxford's Letter from the Court, the 21st of May 1578 in The Mysterious William Shakespeare, pp.602, 603.

121. Frobisher's statement, quoted in The Mysterious William Shakespeare, p.603.

122. Charlton Ogburn, The Mysterious William Shakespeare, p.668-671.

123. Earl of Oxford's Letter dated May 18, 1591 from Lord Oxford to Queen, quoted in The Mysterious William Shakespeare, p.721.

124.Charlton Ogburn, The Mysterious William Shakespeare, p.721.

125. Mark Anderson, Shakespeare by Another Name: The Life of Edward de Vere, Earl of Oxford, The Man Who Was Shakespeare, New York: Gotham Books, 2005, p.184,185.

126. Ian Wilson, Shakespeare: The Evidence, New York: St. Martin's Griffin, 1993, pp.19, 20.

127.W.F.C. Wigston, Bacon, Shakespeare and the Rosicrucians, p.261.

128. Ibid., pp.283,284.

129. Queen Elizabeth I, "Privy Seal Warrant," found in The Mysterious William Shakespeare, p.688. 
130.Charlton Ogburn, The Mysterious William Shakespeare, p.453

131. Ibid., p.453.

132. Edward de Vere, "Labour and Its Reward," Poems of Edward de Vere, Shakespeare Oxford Fellowship, http://shakespeareoxfordfellowship.org/poems-ofedward-de-vere/

133. Ibid.

134. William T. Smedley, The Mystery of Francis Bacon, pp. $98,99$.

135. Ibid., p.102.

136. Ibid.

137. Numerical Cypher Chart, http://www.sirbacon.org/links/doddnum.html.

138. William T. Smedley, The Mystery of Francis Bacon, p. 105.

139. "Secret Bacon," The Francis Bacon Research Trust, http://www.fbrt.org.uk/pages/bacon_secret.html.

140. Wigston, W. F. C. Bacon, Shakespeare and the Rosicrucians, London: G. Redway, 1888, p.xiii.

141. Ibid., p.xvii.

142. "Great Instauration," quoted in Bacon, Shakespeare and the Rosicrucians, 169,170.

143. Title of Francis Bacon's "Great Instauration," quoted in Bacon, Shakespeare and the Rosicrucians, Footnote, p.170.

144. Wigston, W. F. Bacon, Shakespeare and the Rosicrucians, pp.170, 171.

145. Francis Bacon, "Novum Organum," quoted in Bacon, Shakespeare and the Rosicrucians, p.172

146. Francis Bacon, Preface to the "Advancement of Learning," quoted in The Mystery of Francis Bacon, p.104.

147. Ibid.

148. Ibid.

149. Francis Bacon, "Retired Courtier," quoted in Bacon, Shakespeare and the Rosicrucians, p.244.

150. William T. Smedley, The Mystery of Francis Bacon, US: Literary Licencing LLC, 2014, republished from 1912 original, pp.101,102.

151. Wigston, W. F. C. Bacon Shakespeare and the Rosicrucians, p.xvii.

152. Ibid., xviii.

153. Ibid. xix.

154. Ibid., p.76.

155. Ibid., pp.77, 78.

156. Ibid., pp.148, 149.

157. Ibid., p.151.
158. Ibid., p.102.

159. Ibid., p.87.

160. Ibid. p. 100.

161. Ibid, p.109.

162. Ibid., p.113.

163. Ibid., 135.

164. Ibid., p.137.

165. Peter Dawkins, "Shakespeare and Freemasonry," 1997, http://www.sirbacon.org/Dawkinsfrmsnry.htm.

166. Ibid.

167. Ibid.

168. Ibid.

169. Ibid.

170. Alfred Dodd, Francis Bacon's Personal Life Story, p.161.

171. Dorothy and Charlton Ogburn Sr., pp.1208, 1209.

172. Ibid, pp.1210, 1211.

173. Peter Dawkins, Shakespeare and Freemasonry, 1997, from http://sirbacon.org/Dawkinsfrmsnry.htm

174. Wigston, W. F. C. Bacon, Shakespeare and the Rosicrucians. London: Redway, 1888,Preface, xviii.

175. Christopher Knight and Robert Lomas, The Hiram Key. London: Arrow Books, Ltd., 1997, 175.

176. Peter Dawkins, "Shakespeare and Freemasonry".

177. Ibid, pp.134, 135.

178. Peter Dawkins, Shakespeare and Freemasonry.

179. Wigston, W. F. C. Bacon, Shakespeare and the Rosicrucians, p.174.

180. Peter Sammartino, The Man Who Was William Shakespeare, pp.11, 12.

181. Paul Streitz, Oxford: Son of Queen Elizabeth I. Darien, CT: Oxford Institute Press, 2001, p.98.

182. John Mitchel, pp.174, 175.

183. Charlton Ogburn Jr. The Mysterious Wm. S., p.765.

184. Dorothy and Charlton Ogburn Sr., p.1198.

185. Charlton Ogburn Jr. The Mysterious Wm. S., p.43.

186. John Mitchel, p.162.

187. Taken from the Masonic ritual of the First Degree from http://www.sacredtexts.com/mas/dun/dun02.htm.

188. Charlton Ogburn Jr. The Mysterious Wm. S., pp.656, 657.

189. Charlton Ogburn Jr. The Mysterious Wm. S., p.656.

190. Paul Streitz, Oxford: Son of queen Elizabeth I, p.138.

191. Wigston, W. F. C. Bacon, Shakespeare and the Rosicrucians, p.261.

192. Ibid., pp.283,284. 